\author{
UNIVERSIDADE DE SÃO PAULO \\ MUSEU DE ARQUEOLOGIA E ETNOLOGIA \\ PROGRAMA DE PÓS-GRADUAÇÃO EM ARQUEOLOGIA
}

\title{
SIG ARQUEOLOGIA:
}

APLICAÇÃO EM PESQUISA ARQUEOLÓGICA

Nilton Ricetti Xavier de Nazareno

Tese apresentada ao Programa de Pós-Graduação em Arqueologia do Museu de Arqueologia e Etnologia da Universidade de São Paulo, para obtenção do título de Doutor em Arqueologia.

Orientador: Prof. Dr. José Luiz de Morais 


\section{UNIVERSIDADE DE SÃO PAULO}

MUSEU DE ARQUEOLOGIA E ETNOLOGIA

PROGRAMA DE PÓS-GRADUAÇÃo EM ARQUEOLOGIA

SIG ARQUEOLOGIA:

APLICAÇÃO EM PESQUISA ARQUEOLÓGICA

Nilton Ricetti Xavier de Nazareno

São Paulo

2005 
Este trabalho é dedicado às mulheres da minha vida, Bernadete, Luísa e Thaís. 


\section{AGRADECIMENTOS}

As mudanças nas nossas vidas são precedidas de pessoas que de alguma forma contribuem e nos estimulam a sair do mesmismo. Foi assim com a minha entrada no mundo estimulante da arqueologia onde, sem abandonar a minha formação inicial, tenho procurado contribuir, desde 1995, com uma gama enorme de pesquisadores que da mesma forma que eu, enveredaram por este caminho.

Este trabalho é um dos marcos dessa transformação, e assim gostaria de externar os meus sinceros agradecimentos a todas as pessoas que de alguma forma contribuíram para a finalização deste, e em especial aos meus amigos:

José Luiz de Morais, pela orientação, apoio e por ter depositado confiança na minha capacidade profissional;

Dilamar Candida Martins, por ter me convidado a fazer parte de sua equipe e pelo apoio irrestrito a realização deste trabalho;

Gilson Rodolfo Martins e Everaldo Pinto Conceição que me incentivaram a buscar novos horizontes e redirecionar minha vida profissional;

Marize Farah que se dispôs a fazer a correção ortográfica deste trabalho sem interferir no estilo de escrita do autor;

Fábio Carneiro Lôbo, pela troca de idéias sobre como concretizar computacionalmente a parte experimental deste trabalho;

e colegas do Laboratório de Arqueologia, pelo apoio.

Agradeço também ao:

Centro Federal de Educação Tecnológica de Goiás (CEFET-GO), pela cessão dos softwares utilizados neste trabalho;

Museu Antropológico da Universidade Federal de Goiás (MA/UFG), pelo apoio logístico. 


\section{SUMÁRIO}

LISTA DAS FIGURAS ….................................................................. vi

LISTA DE TABELAS ........................................................................ viii

LISTA DE ABREVIATURAS E SIGLAS ….............................................. ix

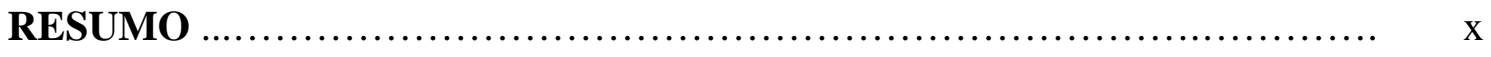

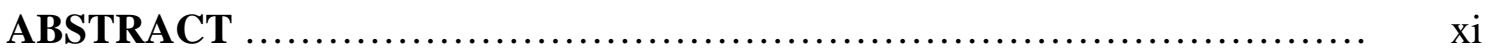

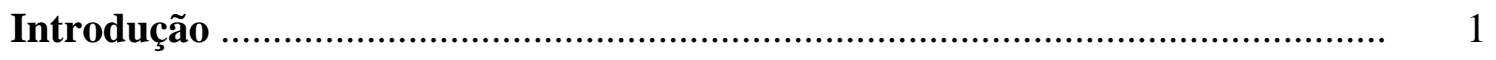

Capítulo I - Sistema de Informações Geográficas - conceituação teórica ......... 9

1.1 - Um breve histórico .......................................................................... 9

1.2 - Definições ........................................................................................... 11

1.3 - Componentes de um SIG ................................................................... 14

1.3.1 - As várias concepções de SIG (arquitetura) .......................................... 15

1.3.1.1 - SIG tradicional ............................................................................ 17

1.3.1.2 - Arquitetura dual ........................................................................... 18

1.3.1.3 - SIG baseado em CAD …................................................................. 20

1.3.1.4 - SIG relacional .............................................................................. 21

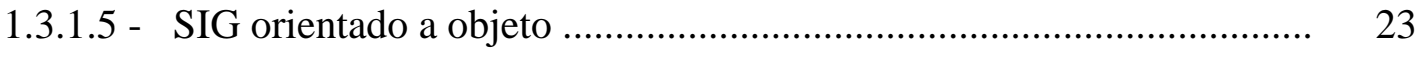

1.3.1.6 - Desktop mapping ….................................................................... 25

1.3.1.7 - SIG baseado em imagens ........................................................... 26

1.3.1.8 - SIG integrado (matrizes-vetores) …............................................... 27

1.3.1.9 - Acesso a dados via Internet ........................................................... 29

1.4 - Funcionamento de um SIG ............................................................. 30

1.4 .1 - Entrada de dados ................................................................................. 32

1.4.2 - Gerenciamento e recuperação de informações ...................................... 34 
1.4.3 - Manipulação e análise .......................................................................... 35

1.4.4 - Exibição e produção cartográfica …………………………………………. 37

1.5 - Critérios para a escolha de um SIG …………………………………..... 37

1.6 - Desenvolvimento de SIG - tendências ..................................................... 39

1.7 - Sistemas Gerenciadores de Banco de Dados ................................................ $\quad 41$

Capítulo II - SIG aplicado à arqueologia - uma análise crítica .......................... $\quad 45$

2.1 - SIG Arqueologia enquanto modelo teórico …………………………….... 49

2.2 - O problema da geração da base cartográfica …………………………..... 54

2.3 - A aplicabilidade do modelo preditivo ........................................................ 58

Capítulo III - O uso da tecnologia de SIG no contexto da inclusão social ....... 61

3.1 - A questão da preservação do patrimônio arqueológico ............................... 61

3.2 - SIG enquanto instrumento de socialização do conhecimento ..................... 62

3.3 - SIG aplicado à inclusão social .................................................................... 63

3.4 - Estruturação dos dados visando o SIG aplicado à inclusão social ............. 77

3.5 - SIG Arqueologia: aplicação em pesquisa arqueológica .............................. 84

Capítulo IV - Conclusões e Recomendaç̃̃es ........................................................ 97

Referências Bibliográficas ........................................................................ 102

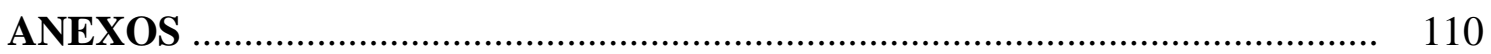




\section{LISTA DE FIGURAS}

Figura 1 - Municípios atingidos pela UHE Corumbá IV

Figura 2 - Área de influência do lago da UHE Corumbá IV

Figura 3 - Visão esquemática da tecnologia de SIG

(adaptada de http://www.fatorgis.com.br)

Figura 4 - Arquitetura genérica dos SIGs (adaptada de Câmara, 2001)

Figura 5 - Representação esquemática de um SIG tradicional (adaptada de Câmara, 2001)

Figura 6 - Representação esquemática da arquitetura DUAL (adaptada de Câmara, 2001)

Figura 7 - Representação gráfica de SIG baseado em CAD (adaptada de Câmara, 2001)

Figura 8 - SIG relacional (adaptada de Câmara, 2001)

Figura 9 - SIG baseado em objetos (adaptada de Câmara, 2001)

Figura 10 - Arquitetura das soluções desktop mapping (adaptada de Câmara, 2001) ........

Figura 11 - Arquitetura de SIG baseado em imagem (adaptada de Câmara, 2001)

Figura 12 - Arquitetura de SIG integrado (adaptada de Câmara, 2001)

Figura 13 - Modelo hierárquico

Figura 14 - Modelo de rede

Figura 15 - Modelo relacional 
Figura 16 - O paradigma dos quatro universos proposto por GOMES e VELHO (1995) apud Câmara (2001)

Figura 17 - Carta Internacional do Mundo ao Milionésimo. Articulação das folhas sobre o Brasil

Figura 18 - Mapa de classes de probabilidade de ocorrências. (THOMAZ, 2002) ........

Figura 19 - Barragem e arranjo geral da obra da UHE Corumbá IV

Figura 20 - Sítios arqueológicos registrados pelo PA-SALV-C/IV na área de influência da UHE Corumbá IV

Figura 21 - Ocorrências arqueológicos registrados pelo PA-SALV-C/IV na área de influência da UHE Corumbá IV

Figura 22 - Pontos percorridos no universo da pesquisa 73

Figura 23 - Classificação dos sítios arqueológicos segundo sua tipologia . PA-SALV-C/IV

Figura 24 - Classificação dos sítios arqueológicos segundo sua proximidade cultural. PA-SALV-C/IV

Figura 25 - Classificação dos sítios arqueológicos segundo seu grau de degradação versus declividade. PA-SALV-C/IV

Figura 26 - Classificação dos sítios arqueológicos segundo seu nível de degradação versus hipsometria. PA-SALV-C/IV.

Figura 27 - Menus interativos do SIG Arqueologia

Figura 28 - Links adicionados às fichas de cadastro de sítios

Figura 29 - Imagens fotográficas ativadas pelo link da ficha de cadastro de sítios ... 
Figura 30 - Planta de localização ativada pelo link da ficha de cadastro de sítios ....

Figura 31 - Modelo digital de terreno ativados pelo link da ficha de cadastro de sítios

Figura 32 - Forma de vinculação efetuada pelo ImageMapper

Figura 33 - Diagrama esquemático do SIG Arqueologia

95

Figura 34 - Conteúdo do CD Rom SIG Arqueologia

96

\section{LISTA DE TABELAS}

Tabela 1 - Comparação entre representações para mapas temáticos (Câmara, 2001)

Tabela 2 - Comparação entre grades regulares e triangulares para representar modelo numéricos de terreno (Câmara, 2001)

Tabela 3 - Situação do mapeamento do território brasileiro (2003) 55

Tabela 4 - Sítios arqueológicos registrados na área de influência da UHE Corumbá IV

Tabela 5 - Ocorrências arqueológicos registrados na área de influência da UHE Corumbá IV

Tabela 6 - Cartas topográficas utilizadas no PA-SALV-C/IV 76 


\section{LISTA DE ABREVIATURAS E SIGLAS}

\begin{tabular}{|c|c|}
\hline CAD & Computer Aided Design \\
\hline CONAMA & Conselho Nacional de Meio Ambiente \\
\hline DDE & Dynamic Data Exchange \\
\hline DPI & Divisão de Processamento de Imagens \\
\hline GIS & Geographic Information System \\
\hline GUI & Graphical User Interface \\
\hline IHS & Intensity, Hue, Saturation (padrão digital de representação de cor) \\
\hline LabArq & Laboratório de Arqueologia do Museu Antropológico da UFG \\
\hline MA & Museu Antropológico da UFG \\
\hline MDT & Modelo Digital de Terreno \\
\hline MNT & Modelo Numérico de Terreno \\
\hline OBDC & Open Database Conectivity \\
\hline OLE & Object Linking and Embedding \\
\hline PA-SALV-C/IV & Projeto de Salvamento Arqueológico da UHE Corumbá IV \\
\hline PA-SALV-SM & $\begin{array}{l}\text { Projeto de Salvamento Arqueológico Pré-Histórico da Usina } \\
\text { Hidrelétrica Serra da Mesa }\end{array}$ \\
\hline RGB & Red, Green, Blue (padrão digital de representação de cor) \\
\hline SAB & Sociedade de Arqueologia Brasileira \\
\hline SAGA & Sistema de Análise Geo-Ambiental \\
\hline SAGRE & Sistema Automatizado de Gerência de Rede Externa \\
\hline SGBD & Sistema Gerenciador de Base de Dados \\
\hline SGBDR & Sistema Gerenciador de Base de Dados Relacional \\
\hline SGI & Sistema Geográficas de Informações \\
\hline SGPAB & Sistema de Gerenciamento do Patrimônio Arqueológico Brasileiro \\
\hline SIG & Sistema de Informações Geográficas \\
\hline SITIM & Sistema de Tratamento de Imagens \\
\hline SPRING & Sistema de Processamento de Informações Geográficas \\
\hline SQL & Structured Quary Langue \\
\hline UFG & Universidade Federal de Goiás \\
\hline VBA & Visual Basic Aplication \\
\hline
\end{tabular}




\section{RESUMO}

A Arqueologia investiga os diferentes processos de constituição, funcionamento e transformação ocorridos nos sistemas sócio-culturais de populações humanas, desde os períodos mais recuados até os dias atuais. A investigação arqueológica é feita por meio de procedimentos técnicos e metodológicos já consagrados, utilizando-se da prática interdisciplinar e do aproveitamento, cada vez mais crescente, de recursos tecnológicos de domínio científico.

A introdução dos sistemas de informação geográfica (SIG) como uma ferramenta de análise no âmbito da arqueologia brasileira é algo recente. A literatura mostra que em outros países o uso de tecnologia é parte da rotina, envolvendo aspectos locais, regionais e de gerenciamento do patrimônio.

Neste trabalho é proposto o uso do SIG como um instrumento de devolução do conhecimento arqueológico, de modo a funcionar como um fator de inclusão social. Para isso é feito um estudo sobre os conceitos envolvidos na tecnologia de SIG e uma análise da problemática na construção de SIGs preditivos em função da precariedade da cartografia nacional. A partir deste estudo é concebido um sistema SIG/Multimídia denominado SIG Arqueologia, onde os dados do Projeto de Salvamento Arqueológico da UHE Corumbá IV (PA-SALV-C/IV) são utilizados para comprovar a eficiência da proposta.

Palavras chaves: Arqueologia; Sistemas de Informações Geográficas; SIG Arqueologia; Preservação; Patrimônio Arqueológico. 


\begin{abstract}
Archeology examines different proceedings of constitution, performance and changes occurred in policies of human populations, social and cultural, since old time till this day. Archaeological search is made through consecrated technical and methodological procedures, using interdisciplinary and profiting training, increased more and more in technological resources of scientific origin

The introduction of geographical information systems (GIS) as an utensil of analysis in the field of brazilian archaeology is recent. Literature shows that in other countries the use of this technology is part of routine, involving local aspects, regional and patrimony management.

In this work is proposed the use of GIS as an instrument of devolution of archeological knowledge, so to operate as a factor of social inclusion. It is made a study for this about concepts involved in GIS technology and an analysis of problematic in predicted GIS in function of precariousness of national cartography. Following this study is conceived a GIS/Multimedia system named 'SIG Arqueologia', were data of archeological salvation project of the UHE CORUMBÁ IV (PA-SALV-C/IV) are utilized to show the efficiency of proposal.
\end{abstract}

Key words: Archaeology, Geographical Information System, GIS Archaeology; Archaeological patrimony; preservation. 


\section{Introdução}

A Arqueologia, instituída como uma Ciência Social, investiga os diferentes processos de constituição, funcionamento e transformação ocorridos nos sistemas sócioculturais de populações humanas, desde os períodos mais recuados até os dias atuais. A investigação arqueológica é feita por meio de procedimentos técnicos e metodológicos já consagrados, utilizando-se da prática interdisciplinar e do aproveitamento, cada vez mais crescente, de recursos tecnológicos de domínio científico.

A Arqueologia tem como objeto de estudo, além de outras fontes, os testemunhos materiais representantes de aspectos culturais das populações pretéritas que permaneceram em locais adequados para passagens ou assentamentos prolongados. Os vestígios, de natureza diversa e característicos de diferentes atividades humanas, são estudados a partir de princípios definidos pela Arqueologia, com a colaboração de respostas exercitadas por Disciplinas que mantêm interfaces amigáveis com essa ciência. Presente em ambientes específicos, o arqueólogo conta também com a colaboração dos habitantes atuais, além do aparato tecnológico já disponível, para a localização de áreas de interesse arqueológico, denominadas pela categoria profissional de sítios arqueológicos.

A identificação desses locais e a preservação dos testemunhos neles contidos representam preocupação da sociedade brasileira desde a terceira década do século XX.

Sobre o patrimônio cultural, existe legislação específica disciplinando o assunto, como o Decreto-Lei n. ${ }^{\circ}$ 25, de 30 de novembro de 1937 - que define patrimônio histórico e artístico nacional, e a Lei Federal n. ${ }^{\circ} 3924$ de 27 de julho de 1961 - que dispõe sobre os monumentos arqueológicos e pré-históricos. 
Com a promulgação da Lei n. ${ }^{\circ}$ 6.938, de 31 de agosto de 1981, que dispõe sobre a política nacional do meio ambiente, é que o Brasil passou a estabelecer instrumentos destinados à “preservação, melhoria e recuperação da qualidade ambiental”. Apesar dessa Lei ter sido promulgada em 1981, somente em 1986 com a publicação da resolução CONAMA ${ }^{1}$ n. ${ }^{\circ}$ 1, conforme Diário Oficial da União (D.O.U. de 2 de janeiro de 1986), é que a avaliação de impactos ambientais passou a ser adotada para diferentes situações que provocam a degradação do ambiente. Em 1987, tendo como base legal a Resolução CONAMA n. ${ }^{\circ} 6$ (D.O.U. de 22 de outubro de 1987), as regras gerais para o licenciamento de obras causadoras de impactos ambientais foram estabelecidas. Segundo Martins (1999, p. 63), a referida Resolução situa o homem como parte da natureza e "nesse sentido, enquanto elemento integrante da natureza, capaz de modificá-la e de influenciar em seu destino. O registro arqueológico, testemunho de comunidades antigas, precisa ser recuperado quando ameaçado por empreendimentos 'desenvolvimentistas.'... Esse registro, recuperado em diferentes contextos ambientais, integra o patrimônio cultural das nações”.

Embora a legislação seja relativamente antiga, somente com a promulgação da Constituição da República Federativa do Brasil, de 5 de outubro de 1988, é que o patrimônio arqueológico passou a ser considerado bem da União e, sobre a matéria, delegou competências comuns à União, aos Estados, ao Distrito Federal e aos Municípios.

A partir de então, os programas ambientais de Arqueologia passaram a ser obrigatórios, representando ações mitigatórias sobre o patrimônio arqueológico, quando da construção de obras impactantes ao meio físico, caso dos aproveitamentos hidroenergéticos (construção de hidroelétricas), aberturas de estradas, obras de gazodutos, entre outras obras de engenharia. Essa demanda do meio empresarial, proporcionou o surgimento da rotulada “Arqueologia de contrato”, “Arqueologia de salvamento”. Ao mesmo tempo, exigiu o início de reflexão e debate sobre essa modalidade de investigação arqueológica que, 
segundo Morais (2002, p.24), “melhor seria entender o que se chama de Arqueologia de contrato como Arqueologia no licenciamento ambiental”.

Essa modalidade de pesquisa arqueológica não difere em essência daquela realizada a longo prazo (Arqueologia rotineira), de acordo com as reflexões expressas por Menezes (1988) e Morais (1990).

Segundo Morais (2002, p.24), a “Arqueologia no licenciamento ambiental é uma Arqueologia diferente, não pela qualidade, excelência ou competência, mas pelo seu ritmo, pela sua agenda. Pelo seu compasso perfeito com o empreendimento que a está gerando. E, nesse caso, a Arqueologia deve assumir um papel inalienável naquilo que lhe compete: contribuir para que o empreendimento potencialmente lesivo ao meio ambiente se torne digno de uma qualificação que poderia ser assim expressa: legítimo porque sustentável.”

A utilização de geotecnologias veio ampliar as possibilidades e agilizar a pesquisa arqueológica, tanto rotineira como a de salvamento. Trabalhos apresentados em congressos e em revistas especializadas da área, tem abordado o assunto, como Beber (1995 e 1997), Beber e Peixoto (1997), Buarque e Correa (1997), Franco (1995 e 1999), Morais (1995), Peixoto (1997), Peixoto e Isquierdo (1997), Rubin e Silva (1999) e Tenório (1995). Boa parte desses trabalhos deixa transparecer a pouca familiaridade dos seus autores com as possibilidades oferecidas por esse ferramental. Os equívocos, naturais de quem está tomando contato inicial com essa tecnologia, decorrem da ausência de domínio técnico-científico do instrumental e do desconhecimento das geotecnologias disponíveis para a Arqueologia e as demais disciplinas científicas. 
Outro fato a ser destacado é o grande número de trabalhos relativos às questões do geoprocessamento aplicado à Arqueologia, apresentados no ano de 1997 no Congresso da Sociedade de Arqueologia Brasileira (SAB), no Rio de Janeiro. O mais preocupante é o total desaparecimento da temática no congresso seguinte da categoria, realizado em 1999. O crescimento do interesse pela temática de 1995 para 1997, indicaria um novo aumento da reflexão sobre o assunto no ano de 1999, o que absolutamente não aconteceu. Pode-se, a partir dessa constatação, especular que talvez o assunto ainda seja “indigesto” para a maioria dos profissionais envolvidos com a Arqueologia Brasileira.

Contudo, em função da demanda e do crescimento das obras impactantes, a inevitável necessidade de trabalhos de salvamento arqueológico, e o conseqüente aumento dos dados a respeito da Arqueologia Brasileira, torna-se premente o uso das geotecnologias e a geração de cultura do geoprocessamento adequado à investigação arqueológica, seja ela na modalidade rotineira ou na de salvamento.

Morais (1995, p. 539) em seu trabalho intitulado "SIG-Arqueologia : Perspectivas de Aplicação em Programas de Pesquisa”, discute as diretrizes necessárias para implantação do SIG (Sistema de Informações Geográficas) em programas de investigação arqueológica. Tenta, segundo suas próprias palavras, "normatizar e implementar os usos possíveis dos recursos de informática a partir de dados e informações resultantes do exercício da atividade fim, ou seja, a Arqueologia”.

Nesse trabalho foi feita uma proposta metodológica para a implantação do SIG / Arqueologia no Projeto Paranapanema, que estava sob sua responsabilidade. Posteriormente, essa idéia foi transposta para o Projeto de Salvamento Arqueológico PréHistórico da Usina Hidrelétrica Serra da Mesa - PA-SALV-SM, desenvolvido pela Universidade Federal de Goiás, com apoio e colaboração de instituições como Universidade de São Paulo (USP), Universidade Estadual Paulista (UNESP - Campus de Pres. Prudente), Universidade Federal do Mato Grosso do Sul e Universidade Católica “Dom Bosco” de Campo Grande, do Mato Grosso do Sul. A idéia foi posta em prática, 
porém, por problemas operacionais, relatados no relatório final da pesquisa ("Subprograma SIG - Arqueologia (Geoprocessamento)”, v. 2, 1998), não foi totalmente executada.

No ano de 2002, finalmente foi defendida no País, a primeira tese na área de SIG aplicado à Arqueologia, intitulada "O uso de SIG na predição da localização de sítios arqueológicos: um estudo de caso na bacia do Paraná Superior”, pela arqueóloga Rosângela Custódio Cortez Thomaz, sob a orientação do Prof. Dr. José Luiz de Morais. Nesse trabalho foi feito o estudo numa faixa de aproximadamente $40 \mathrm{~km}$, ao longo do Rio Paraná, com o objetivo de gerar cartas de potencial arqueológico.

Em 2004, Andréas Kneip, defendeu a tese “O Povo da Lagoa: uso de SIG para modelamento e simulação na área arqueológica de Camacho”, orientada pelo Prof. Dr. Levy Figuti. O autor utiliza a ferramenta para entender os movimentos do nível médio dos mares e sua influência na ocupação do referido sítio arqueológico.

Um Sistema de Informações Geográficas (SIG) pode ser entendido como um banco de dados não convencional (georreferenciado), com a capacidade de proceder a análises. No âmbito da Arqueologia, onde diferentes tipos de dados devem ser analisados conjuntamente (geológicos, geomorfológicos, climatológicos, arqueológicos, estatísticos, entre outros) é uma ferramenta extremamente poderosa.

Num projeto de salvamento arqueológico onde o fator tempo é importante, pode-se vislumbrar sua aplicação em dois momentos distintos. Num primeiro, quando se está na fase de reconhecimento geral, conforme Redman (1973), o SIG pode indicar os locais mais prováveis de se encontrar sítios arqueológicos na região estudada (Cartas de Potencial Arqueológico). Num segundo momento, quando todos os dados arqueológicos já foram coletados e estudados, o SIG entra como ferramenta de análise, procurando através das diversas interações entre informações arqueológicas ou não, explicar aspectos relativos às populações humanas no passado e como elas ocuparam a região. 
No presente trabalho procura-se estudar a filosofia de construção de SIGs, discutir a sistemática de aquisição de dados e implantar um SIG voltado aos objetivos da Arqueologia. Para tanto, no capítulo 1, é feita uma revisão dos principais conceitos ligados à tecnologia de SIG. Procura-se utilizar uma linguagem acessível para usuários não muito afeitos à terminologia computacional.

No capítulo 2 é feita uma análise crítica sobre a aplicabilidade do SIG preditivo no contexto atual. Embora do ponto de vista teórico seja perfeitamente possível a utilização da ferramenta com esse enfoque, as informações geoambientais normalmente são escassas e em escala inadequada, o que torna complicada a geração das cartas de potencial arqueológico com um nível de detalhamento satisfatório. Outro complicador reside na necessidade de que o usuário do SIG tenha total domínio da ferramenta, inclusive em termos de programação, que na maioria das vezes não é tão simples.

No capítulo 3 é apresentada a proposta de se utilizar a ferramenta enquanto difusor de conhecimento, numa política de devolução social do conhecimento. Foram utilizados dados oriundos do Projeto de Salvamento Arqueológico da UHE Corumbá IV PA-SALV-C/IV (leste goiano) (Figura 01 e Figura 2) para exemplificar como essa devolução pode se processar.

No Capítulo 4, são feitas algumas recomendações e conclusões sobre a utilização da tecnologia de SIG aplicada às necessidades da Arqueologia. 


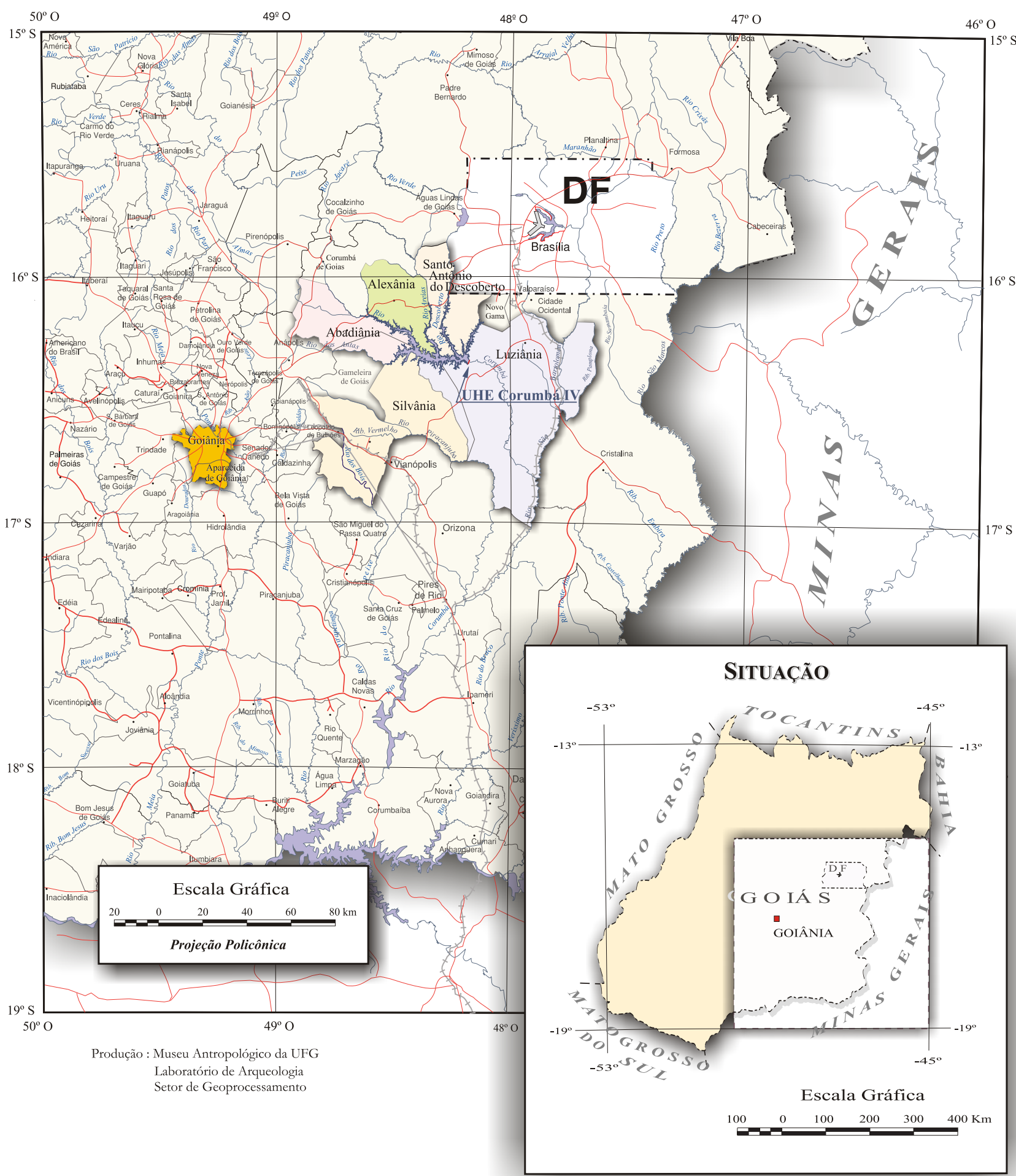

Figura 1 - Municípios goianos abrangidos pela UHE Corumbá IV. 


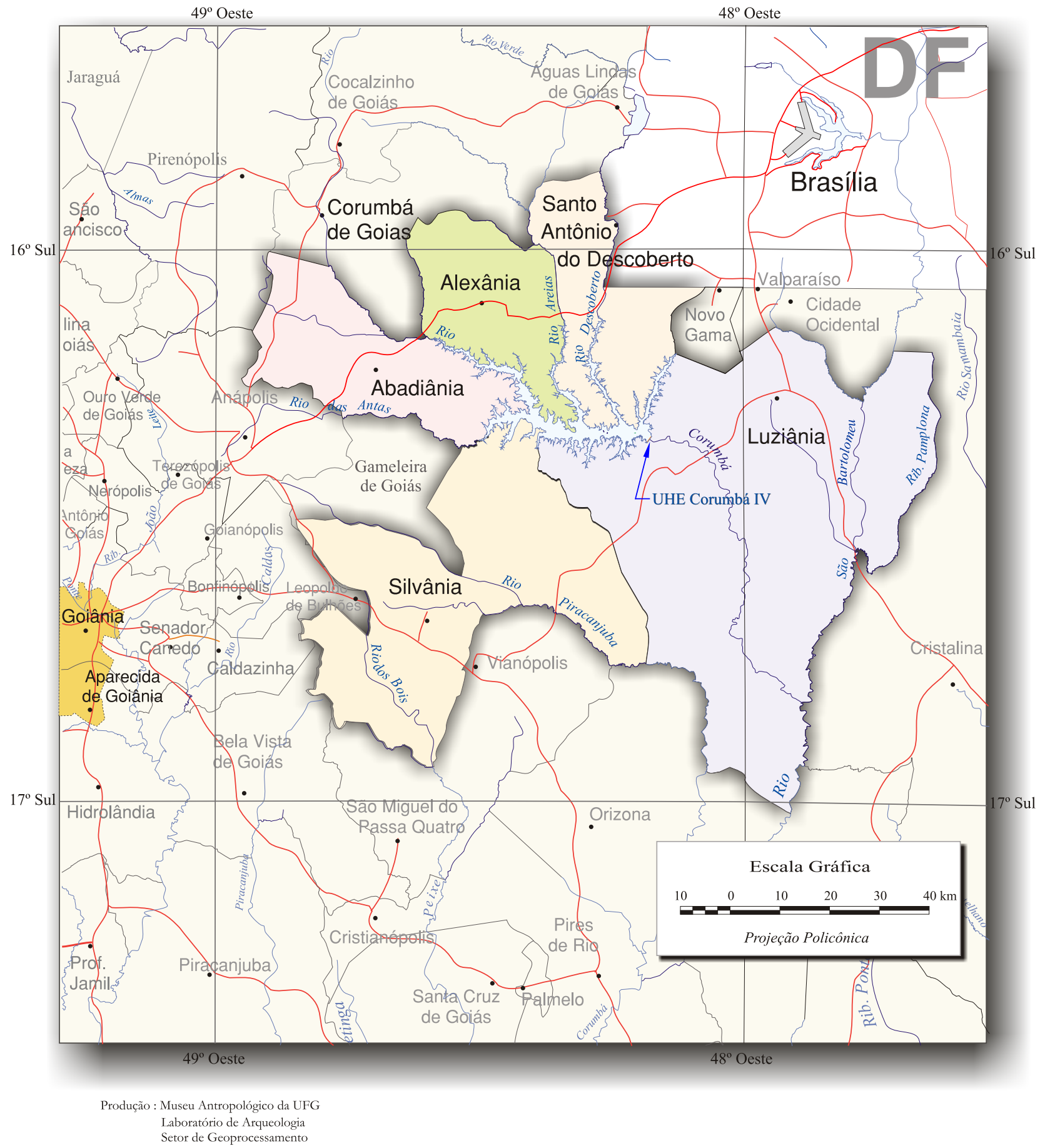

Figura 2 - Área de influência do lago da UHE Corumbá IV. 


\section{Capítulo I - Sistema de Informações Geográficas - conceituação teórica}

\section{1 - Um breve histórico}

Originalmente o conceito de SIG (Sistema de Informações Geográficas) foi desenvolvido nos anos 60, com o objetivo de sobrepor e combinar diversos tipos de dados em um mesmo mapa. Fazia parte de um programa governamental do Canadá, para inventariar os recursos naturais do País. Na época, pela precariedade dos recursos computacionais, o custo do sistema era excessivamente alto. Exigia mão de obra extremamente especializada e, como não existiam alternativas comerciais prontas para uso, obrigava os interessados a desenvolver seus próprios programas. A capacidade de armazenar e processar as informações era muito baixa. Com o avanço dos recursos de hardware, no decorrer da década de 70, e a conseqüente possibilidade de se desenvolver soluções comerciais, apareceu pela primeira vez a expressão Geographic Information System (GIS). Paralelamente, começaram a surgir os primeiros sistemas comerciais de CAD (Computer Aided Design), que melhoraram em muito as condições para a produção de desenhos e plantas para Engenharia, e serviram de base para os primeiros sistemas de cartografia automatizada. Os primeiros fundamentos matemáticos voltados para a cartografia, incluindo os problemas da Geometria Computacional, são dessa fase. Os computadores dessa época eram de grande porte e só grandes instituições tinham condição de acessar essa tecnologia. A década de 80, com o grande avanço na microinformática e o conseqüente barateamento das estações de trabalho gráficas, e ainda o surgimento e evolução dos computadores pessoais e dos sistemas gerenciadores de bancos de dados relacionais, foi marcada pela massificação da tecnologia de SIG que tomou um grande impulso e entrou num período de aceleração que dura até hoje. Nos anos 90, observou-se um crescimento do ritmo de penetração do GIS nas organizações, sempre alavancado pelos custos decrescentes do hardware e do software, e também pelo surgimento de alternativas de menor custo para a construção de bases de dados geográficos. 
Gilberto Câmara relata que no Brasil, os primeiros esforços para divulgar e criar massa crítica com o objetivo de desenvolver a tecnologia de SIG foram feitos com muito empenho pelo professor Jorge Xavier da Silva (UFRJ), no início dos anos 80. A vinda ao Brasil, em 1982, do Dr. Roger Tomlinson, responsável pela criação do primeiro SIG (o Canadian Geographical Information System), incentivou o aparecimento de vários grupos interessados em desenvolver essa tecnologia, entre os quais podem ser citados:

UFRJ: O grupo do Laboratório de Geoprocessamento do Departamento de Geografia da UFRJ, sob a orientação do professor Jorge Xavier, desenvolveu o SAGA (Sistema de Análise Geo-Ambiental). O SAGA tem seu forte na capacidade de análise geográfica e vem sendo utilizado com sucesso como veículo de estudos e pesquisas.

MaxiDATA: os então responsáveis pelo setor de informática da empresa de aerolevantamento AeroSul criaram, em meados dos anos 80, um sistema para automatização de processos cartográficos. Constituíram a empresa MaxiDATA e lançaram o MaxiCAD, software largamente utilizado no Brasil, principalmente em aplicações de Mapeamento por Computador. Posteriormente, o produto dbMapa permitiu a junção de bancos de dados relacionais a arquivos gráficos MaxiCAD, produzindo uma solução para "desktop mapping" (pág. 28) utilizada em aplicações cadastrais.

CPqD/TELEBRÁS: O Centro de Pesquisa e Desenvolvimento da TELEBRÁS iniciou, em 1990, o desenvolvimento do SAGRE (Sistema Automatizado de Gerência da Rede Externa), uma extensiva aplicação de Geoprocessamento no setor de telefonia. Construído com base no ambiente de um SIG (VISION) com um banco de dados cliente-servidor (ORACLE), o SAGRE envolve um significativo desenvolvimento e personalização de software.

INPE: Em 1984, o INPE (Instituto Nacional de Pesquisas Espacias) estabeleceu um grupo específico para o desenvolvimento de tecnologia de geoprocessamento e sensoriamento remoto (a Divisão de Processamento de Imagens - DPI). De 1984 a 1990, a DPI desenvolveu o SITIM (Sistema de Tratamento de Imagens) e o SGI 
(Sistema de Informações Geográficas), para ambiente PC/DOS, e, a partir de 1991, o SPRING (Sistema para Processamento de Informações Geográficas), para ambientes UNIX e MS/Windows.

\section{2 - Definições}

Vários autores propõem definições para essa tecnologia, segundo os seus pontos de vista. A seguir estão relacionadas algumas das definições encontradas na literatura especializada e citadas por Paredes (1994) .

“ ... conjunto automático de funções que provê aos profissionais especializados o armazenamento, a recuperação, manipulação e reprodução gráfica de dados localizados geograficamente " (Ozemoy, 81).

“... conjunto de ferramentas para a coleta, o armazenamento, a recuperação, transformação e reprodução gráfica dos dados espaciais do mundo real para um conjunto particular de finalidades. Este conjunto de ferramentas constitui um SIG ” (Clarke, 86).

"Conjunto poderoso de ferramentas para recolhimento, armazenamento, transformação e visualização de dados espaciais do mundo real ” ( Burrough, 1986).

"Sistema de bases de dados em que a maior parte dos dados estão indexados espacialmente e sobre os quais se pode operar um conjunto de procedimentos para responder a questões sobre as entidades espaciais” ( Smith et al, 1987).

"Sistema de apoio à decisão que integra dados referidos espacialmente num ambiente de resolução de problemas" ( Cowen, 1988).

"Sistema computacional para recolher, verificar, integrar e analisar informação relacionada com a superfície da Terra ” ( Rhind, 1988).

"Conjunto de procedimentos manuais ou computacionais usados para guardar e manipular dados referidos geograficamente ” ( Aronoff, 1989).

“ ... os SIGs são sistemas ou ferramentas assistidas por computador para captura, armazenamento, transformação, análise e reprodução gráfica de dados espaciais " (Star \&Estes, 90). 
"Em sentido restrito trata-se de um conjunto de programas residentes num computador que permite introduzir, acessar, manipular e visualizar informação georreferenciadas " (Henriques,1990).

“ Uma tecnologia de informação que armazena, analisa e mostra dados espaciais e/ou nãoespaciais. Entendendo-se por tecnologia, o conjunto de métodos e materiais usados para alcançar um objetivo comum ” (Goodchild, Maguire e Rhind, 1991).

"Os SIG são instrumentos ao serviço da gestão dos recursos naturais e do ordenamento que permitem dispor, em qualquer momento, de um conjunto integrado de dados multi-sectoriais de origens diferentes, facilmente atualizáveis e relacionáveis entre si, através de um referencial comum - um mesmo espaço geográfico " (DGOT).

Segundo Câmara (2001), o termo Sistema de Informações Geográficas (SIG) é aplicado para sistemas que realizam o tratamento computacional de dados geográficos e recuperam informações não apenas com base em suas características alfanuméricas, mas também através de sua localização espacial; oferecem ao administrador (urbanista, planejador, engenheiro) uma visão inédita de seu ambiente de trabalho, em que todas as informações disponíveis sobre um determinado assunto estão ao seu alcance, interrelacionadas com base no que lhes é fundamentalmente comum: a localização geográfica.

O mesmo autor argumenta ainda que as diversas definições existentes mostram a multiplicidade de usos e visões possíveis dessa tecnologia e apontam para uma perspectiva interdisciplinar de sua utilização. Ainda é possível indicar as principais características de SIGs a partir desses conceitos:

- Inserir e integrar, numa única base de dados, informações espaciais provenientes de dados cartográficos, dados censitários e cadastro urbano e rural, imagens de satélite, redes e modelos numéricos de terreno.

- Oferecer mecanismos para combinar as várias informações, através de algoritmos de manipulação e análise, bem como para consultar, recuperar, visualizar e imprimir o conteúdo da base de dados georreferenciados.

É comum encontrar indivíduos que imaginam que um SIG pode ser comprado em lojas especializadas, assim como se adquire um editor de textos ou uma planilha eletrônica. No entanto, o viés computacional é apenas uma faceta. Na verdade a concepção de um SIG 
é mais complexa e envolve não só o software gerenciador, mas também a base de dados, os métodos e procedimentos para manutenção e administração do próprio sistema e, principalmente, o corpo técnico especializado. Em outras palavras, de forma bastante simplificada, um SIG é composto por três elementos distintos e igualmente importantes: o conjunto software/hardware; a base de dados (gráfica e alfanumérica); e a equipe técnica que é responsável pela manutenção e administração do sistema (instituição).

A figura 3, adaptada de http://www.fatorgis.com.br, mostra de modo esquemático, as características principais de um SIG, mencionadas anteriormente.
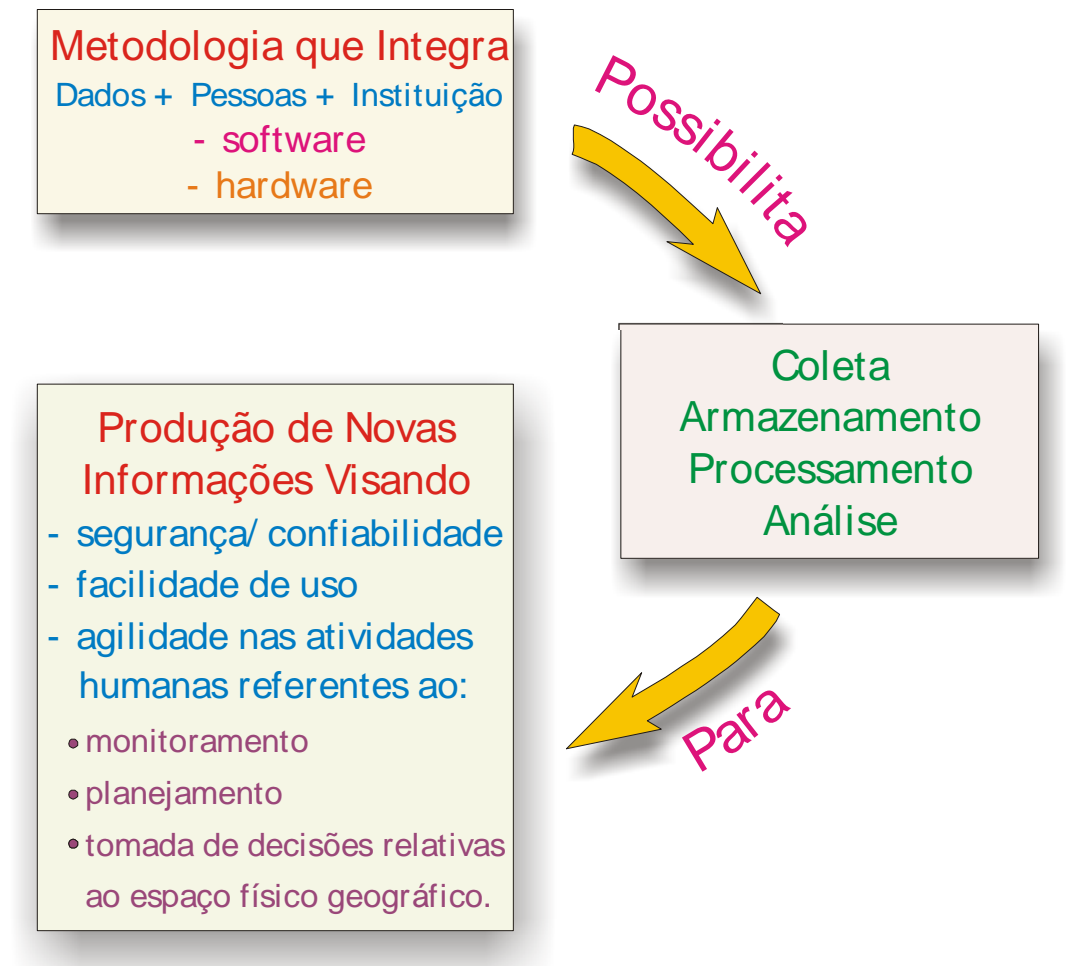

Figura 3 - Visão esquemática da tecnologia de SIG (adaptada de http://www.fatorgis.com.br)

Outro aspecto importante da tecnologia de SIG reside no fato de que cada problema exige uma solução específica. Não existe uma solução de SIG genérica o suficiente, que se ajuste às necessidades de qualquer usuário. É necessário o equacionamento das questões que se pretende abordar para, em seguida, parametrizar a 
base de dados. Em outras palavras, um SIG concebido para auxiliar no planejamento urbano não serve para apoiar um projeto arqueológico, e vice-versa.

\section{3 - Componentes de um SIG}

Segundo Câmara (2001), numa visão bastante abrangente, um SIG tem os seguintes componentes:

- interface com usuário;

- entrada e integração de dados;

- funções de consulta e análise espacial;

- visualização e impressão;

- armazenamento e recuperação de dados (organizados sob a forma de um banco de dados geográficos).

Estes componentes se relacionam de forma hierárquica. No nível mais próximo ao usuário, a interface homem-máquina define como o sistema é operado e controlado. No nível intermediário, um SIG deve ter mecanismos de processamento de dados espaciais (entrada, edição, análise, visualização e saída). No nível mais interno do sistema, a gerência de bancos de dados geográficos deve oferecer o armazenamento e a recuperação dos dados espaciais e seus atributos.

De uma forma geral, as funções de processamento de um SIG operam sobre dados em uma área de trabalho no computador, denominada de memória principal. A ligação entre os dados geográficos e as funções de processamento é feita por mecanismos de seleção e consulta que definem restrições sobre o conjunto de dados. Pode-se, por exemplo, solicitar que o sistema recupere dados relativos à cidade de São Paulo. Neste caso, a restrição se estabelece em função da região de interesse. Por outro lado, pode-se solicitar dados relativos às cidades do Estado de São Paulo com mais de 100.000 
habitantes. A restrição agora se estabelece por dados não espaciais. Finalmente, pode-se solicitar dados relativos aos postos de saúde que estão distantes em, no máximo, 5 km de um hospital. A restrição se dá então por critérios espaciais.

A figura 4 adaptada de Câmara (2001) mostra de forma esquemática a arquitetura genérica dos SIGs.

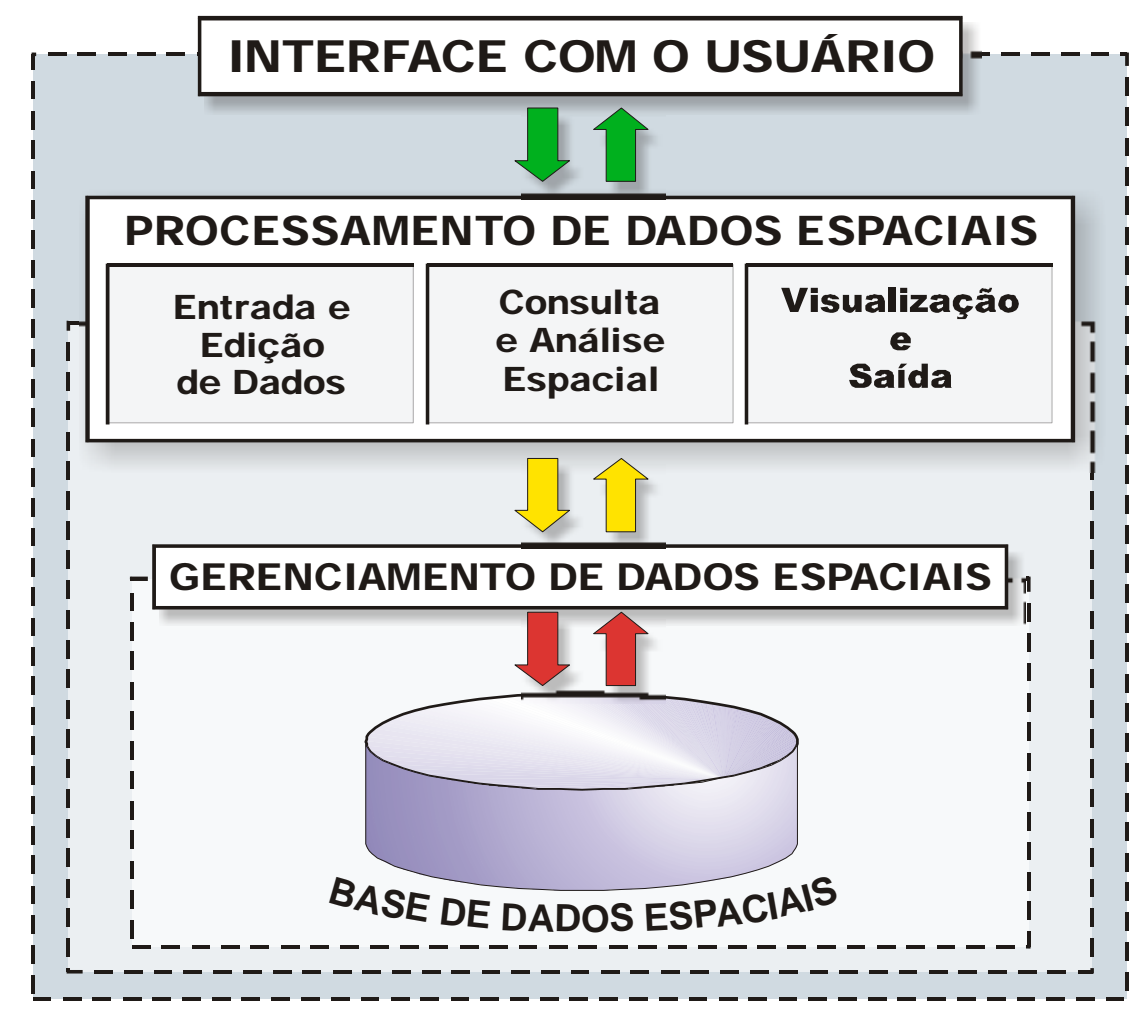

Figura 4 - Arquitetura genérica dos SIG (adaptada de Câmara, 2001).

\subsection{1 - As várias concepções de SIG (arquitetura)}

Os primeiros SIGs foram projetados para resolver um conjunto específico de problemas, tendo evoluído posteriormente para uma ferramenta mais abrangente. Essa vocação inicial, embora não limite sua amplitude de aplicações, acabou por gerar pontos fortes e fracos, dependendo da idealização inicial e das implementações agregadas ao longo do tempo. Essa variedade de arquiteturas, com certeza, tem influência sobre aspectos relativos ao desempenho que está diretamente ligado à capacidade de gerenciamento de 
grandes bases de dados, à utilização simultânea do sistema por mais de um usuário e à integração com outros sistemas.

A partir dessas diferenças conceituais é possível, segundo Câmara (2001), se estabelecer categorias nas quais, com algumas alterações ou maior detalhamento, praticamente qualquer software comercial se insere. Deste modo, pode-se dividi-los nas seguintes categorias:

- $\quad$ SIG tradicional;

- Arquitetura dual;

- $\quad$ SIG baseado em CAD;

- SIG relacional;

- SIG orientado a objetos;

- Desktop mapping;

- $\quad$ SIG baseado em imagens;

- SIG integrado (imagens-vetores).

Segundo o mesmo autor, as cinco primeiras categorias referem-se especificamente a SIGs baseados em vetores, e isto se deve ao fato de que existem muitas variações para a filosofia básica de armazenamento e utilização de vetores. Isto é evidente, principalmente, nas primeiras categorias, enquanto o gerenciamento e processamento de imagens são mais uniformes entre as demais aplicações comerciais. Essa categorização está perdendo a nitidez na medida em que os softwares comerciais evoluem e os sistemas ficam cada vez mais complexos. Atualmente, a evolução está centrada na utilização dessa tecnologia via internet e na busca de uma arquitetura básica para o que se chama de SIGs interoperáveis. 


\subsubsection{1 - SIG tradicional}

Nos primeiros SIGs, o que se buscava era a integração dos dados gráficos e os alfanuméricos num único ambiente computacional. Por essa razão os projetos baseados nessa filosofia são classificados como tradicionais. Nesse tipo de arquitetura o usuário interage através de uma interface gráfica - GUI (Graphical User Interface) ou de uma linguagem de programação. Normalmente, essa linguagem é composta apenas por macrocomandos e, por essa razão, bastante simples. Assim, a linguagem de programação pode funcionar também como uma interface do tipo linha de comando, em que o usuário pode digitar os comandos interativamente. Existe também a possibilidade da personalização da GUI, de modo a incluir macro-comandos ou seqüências de comandos desenvolvidos pelo usuário.

Neste tipo de arquitetura os gerenciamentos da base de dados alfanumérica e gráfica são feitos separadamente. A base gráfica é do tipo proprietária, não se tendo condições de acessá-la diretamente, pois os dados estão armazenados em formato binário (linguagem interna de computador). Neste caso, somente os técnicos de desenvolvimento tem acesso aos códigos fontes. Essa atitude é deliberada e tem o objetivo de garantir o segredo comercial. Os dados alfanuméricos também estão em bases de dados proprietárias, mas geralmente, em forma de tabelas, não sendo complicado interpretar o seu conteúdo. Neste tipo de concepção, as funções de SIG podem estar todas contidas no núcleo de processamento, numa solução dita monolítica. Por questões relativas a futuras implementações no produto, o normal é que estas funções estejam separadas em módulos. Cabe ao núcleo central implementar a funcionalidade básica e o gerenciamento dos dados.

Esta solução permite que os módulos sejam comercializados separadamente o que reduz significativamente o custo na aquisição, pois o próprio usuário monta o seu ambiente de trabalho, adquirindo os módulos necessários à solução de seu problema.

A figura 5 ilustra de forma esquemática um SIG concebido de forma tradicional. 


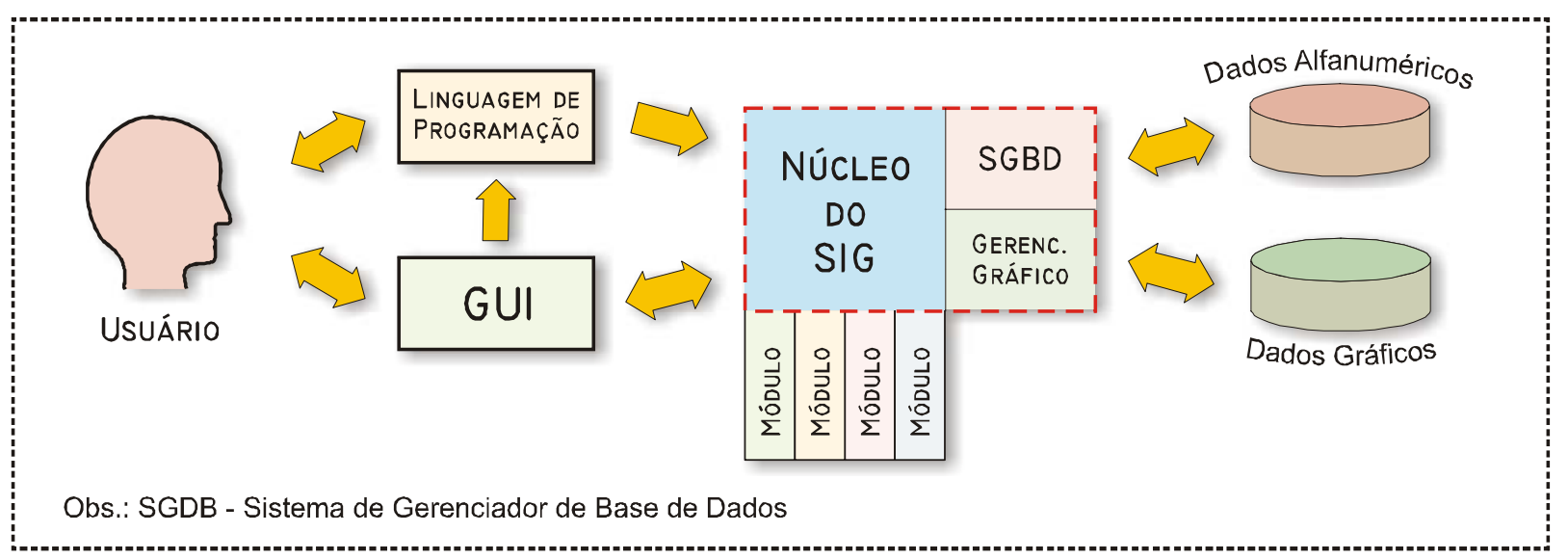

Figura 5 - Representação esquemática de um SIG tradicional (adaptada de Câmara, 2001).

As principais características desse tipo de solução são as seguintes:

- gerenciamento em separado de dados gráficos e alfanuméricos;

- armazenamento de dados gráficos em estruturas proprietárias;

- armazenamento de dados alfanuméricos em banco de dados geralmente proprietário, integrado ao produto (nem sempre relacional);

Um exemplo de um software desenvolvido com essa proposta é o ARC/INFO (básico).

\subsubsection{2 - Arquitetura dual}

$\mathrm{Na}$ arquitetura tipo dual, cuja representação gráfica se encontra na figura 4, o SGBD (Sistema Gerenciador de Base de Dados) é um sistema relacional completo que administra diretamente os dados alfanuméricos, realizando parte das tarefas do SIG. É um banco de dados relacional comum, como o Access da Microsoft, por exemplo, entre outros.

Em termos conceituais pouco muda em relação ao tipo anterior, apenas aumenta a facilidade em se desenvolver o núcleo. Contudo, como o SIG e o SGBD são produtos diferentes, a integração é feita pelo núcleo e está restrita apenas às ações normais de banco 
de dados (inserção, exclusão e consultas). Este tipo de arquitetura é vantajoso por apresentar a alternativa de se ter aplicações convencionais concebidas e desenvolvidas dentro do ambiente do SGBD relacional, compartilhando os atributos alfanuméricos dos objetos geográficos. Porém, a solução é frágil no aspecto da integridade dos dados. Como a base gráfica e a alfanumérica são separadas, é possível que se exclua um registro alfanumérico que compõe um conjunto de atributos para uma determinada entidade geográfica, sem que o SIG tenha controle sobre isso. Deste modo, a informação passa a ser inconsistente.

Assim, segundo Câmara (2001), o acesso a atributos alfanuméricos de dados geográficos só pode ser feito de maneira criteriosa, dentro de controles rígidos que precisam ser implementados pela aplicação, uma vez que o software básico (SIG e SGBD relacional) não oferece qualquer recurso para a garantia automática da integridade dos dados. Este tipo de problema não ocorre na solução anterior porque o acesso aos dados gráficos e alfanuméricos é feito pelo núcleo do SIG. O ambiente, neste caso, é mais controlado.

A principal característica desta arquitetura é o fato de utilizar uma estrutura de banco de dados alfanumérico externo, tipicamente relacional e padrão no mercado.

Um exemplo de sistema nesta arquitetura é o Genasys.

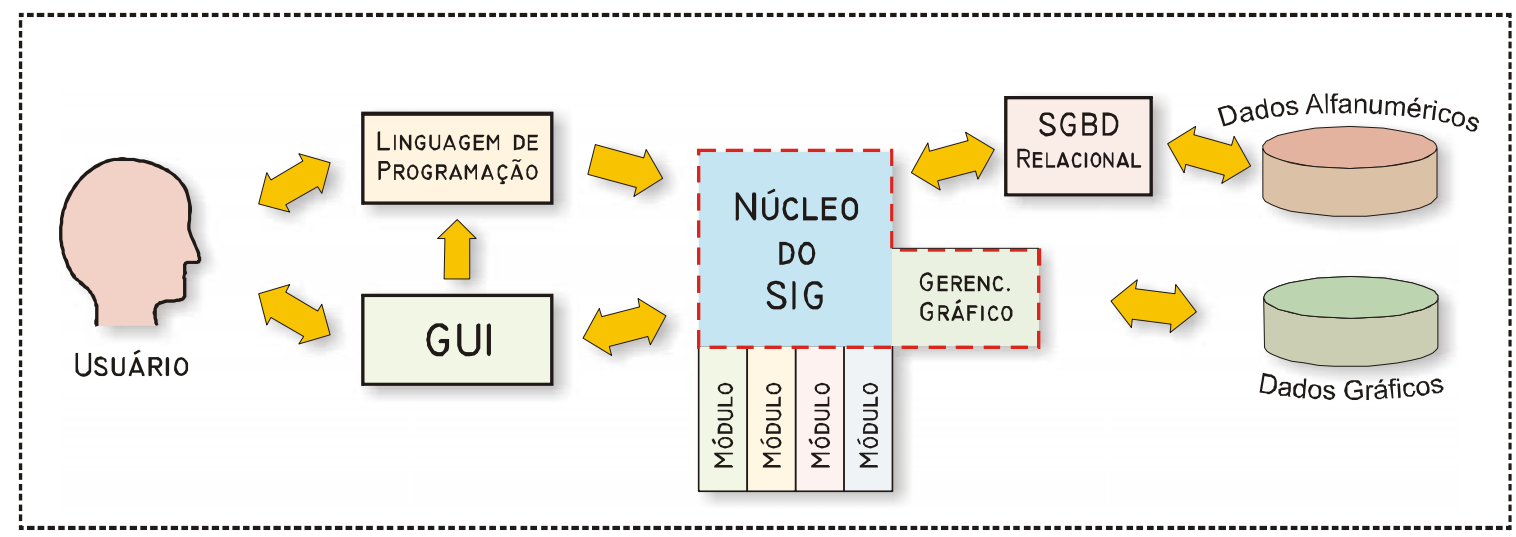

Figura 6 - Representação esquemática da arquitetura Dual (adaptada de Câmara, 2001). 


\subsubsection{3 - SIG baseado em CAD}

Este tipo de arquitetura integra os sistemas CAD (Computer Aided Design) com os SGBD relacionais padrão de mercado (Figura 7). Esta concepção procura aproveitar o que existe de melhor nos dois produtos disponíveis, cabendo ao núcleo do SIG a integração entre os dois, além da implementação de algumas funções geográficas. As funções geográficas mais específicas são oferecidas em módulos à parte. A comunicação é feita através de uma interface gráfica semelhante às do sistema CAD, tornando-a mais familiar para os usuários que tem alguma experiência com a ferramenta CAD. Não se tem uma linguagem de programação específica e sim, em alguns casos, uma macro-linguagem capaz de formular seqüências de comandos disponíveis no ambiente do SIG.

Esta arquitetura apresenta a mesma fragilidade da anterior, ou seja, torna os dados inconsistentes. A fragilidade dessa arquitetura reside no fato de ser possível acessar, tanto os dados gráficos como os alfanuméricos, diretamente pelo sistema CAD e pela SGBD respectivamente, e alterar as bases de dados de forma independente. A consistência só é garantida se os dados forem acessados pelo núcleo do SIG.

Um outro problema desta arquitetura está na utilização das estruturas do arquivo CAD para armazenar os dados gráficos, visto que ela é baseada em armazenamento seqüencial, não havendo meios de se fazer uma indexação espacial. Isto limita o tamanho dos arquivos gráficos, pois o tamanho está relacionado diretamente ao custo computacional para se acessar os dados. Para contornar esse problema é necessário fracionar a base gráfica em diversos arquivos e compor manualmente arquivos auxiliares para ajudar no processo de seleção dos arquivos que serão utilizados na tela. Este custo operacional é muito alto em grandes bases de dados.

A vantagem dessa solução está na facilidade de se editar a base gráfica, através dos recursos do $\mathrm{CAD}$, o que possibilita controlar o volume de dados que será manipulado de uma única vez pelo SIG. 
As principais características dos SIG baseado em CAD são as seguintes:

- gerenciamento de dados gráficos feito por um pacote de CAD, geralmente externo ao SIG;

- gerenciamento de dados alfanuméricos feito por um gerenciador de bancos de dados relacional, geralmente padrão de mercado, externo ao SIG;

- possibilidade de manipulação direta dos arquivos gráficos utilizando o sistema CAD "por fora” do SIG.

Podem ser citados: o MGE/MicroStation, o AutoCAD Map e o dBMapa, como exemplos dessa arquitetura.

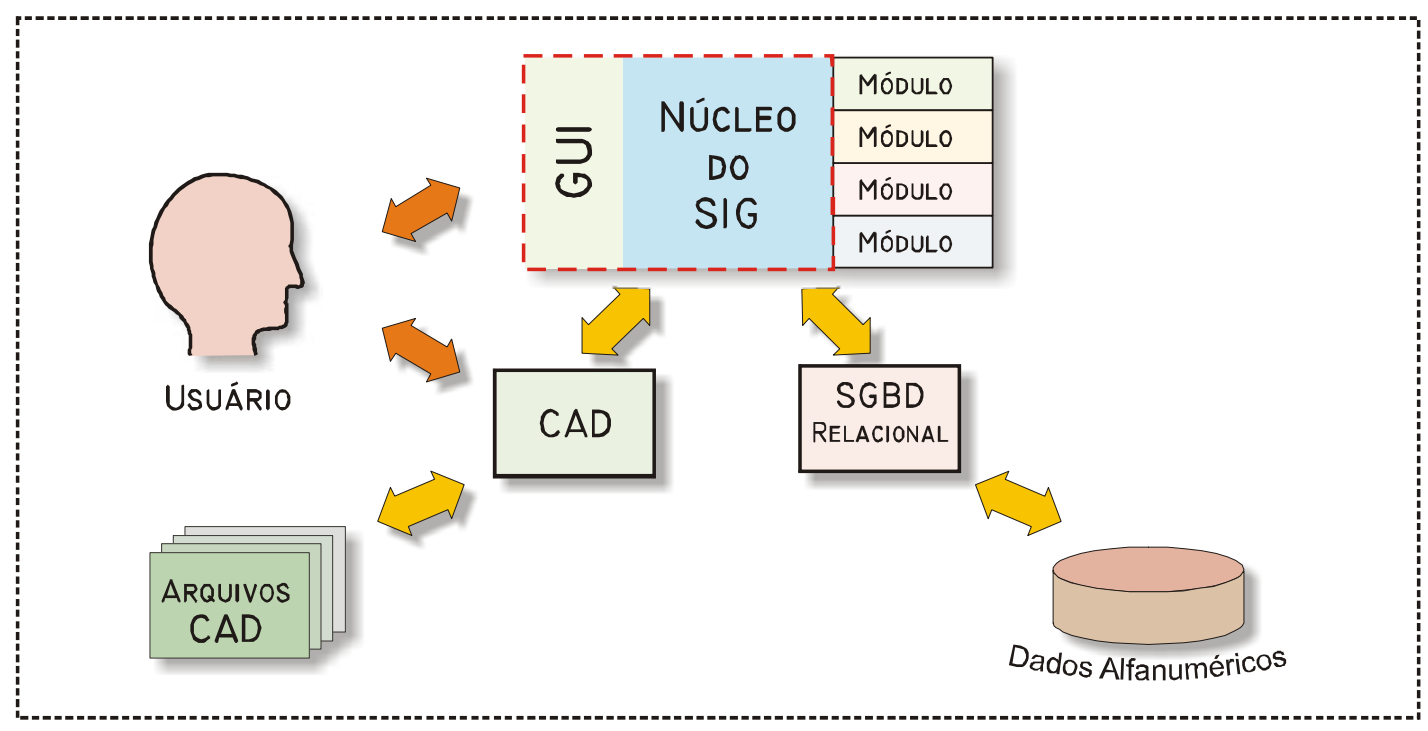

Figura 7 - Representação gráfica de SIG baseado em CAD (adaptada de Câmara, 2001).

\subsubsection{4 - SIG relacional}

Esta proposta surgiu como uma forma de contornar os problemas anteriores, principalmente no que tange à integridade dos dados. Pensou-se também no acesso simultâneo de vários usuários (controle de concorrência). Nesta estrutura, os dados 
gráficos são organizados em tabelas, de forma semelhante aos dados alfanuméricos. A integridade é garantida pelo SGBDR (Sistema Gerenciador de Base de Dados Relacional), que através de um sistema de chaves (campos de indexação específicos nas tabelas) relaciona as tabelas gráficas com as alfanuméricas, além de ser responsável por toda a manipulação das bases de dados. A figura 8 mostra de forma esquemática esse tipo de solução.

Para realizar as consultas e operações mais freqüentes é necessária a implementação de algumas rotinas no núcleo do SIG para que este possa fazer a tradução para operações previamente existentes na SGBD original. Uma das rotinas necessária é a que cria a indexação espacial, providência que otimiza o acesso aos dados gráficos. Outra rotina importante que deve ser implementada é a que introduz na linguagem de consulta SQL (Structured Quary Language), operadores geográficos como “contém”, “contido em”, ou “vizinho a”. Segundo Câmara (2001) essa tarefa está se tornando mais fácil, na medida em que alguns desenvolvedores de SGBDR, como a Oracle e a Informix, estão incorporando facilidades geográficas em seus produtos. Segundo ele, existem produtos mais avançados como o Postgres, que permitem a implementação de novas estruturas de indexação e novos métodos de acesso, o que favorece a implementação de SIGs relacionais.

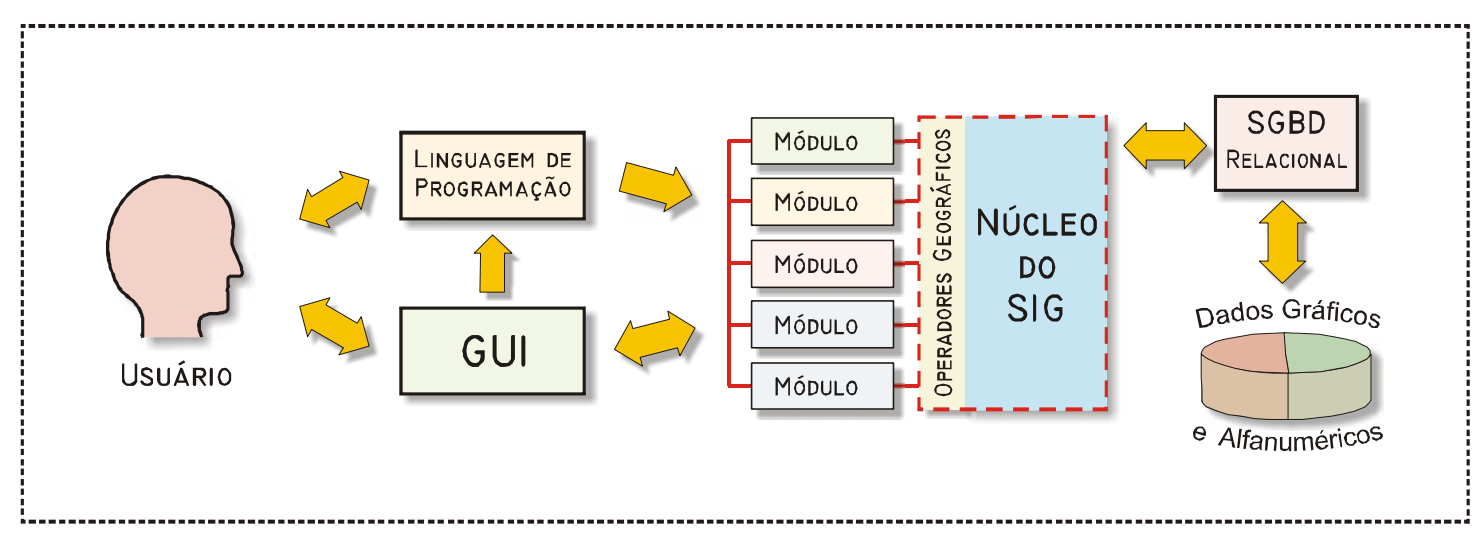

Figura 8 - SIG relacional (adaptado de Câmara, 2001). 
O Vision*GIS é um produto baseado nesta arquitetura, que tem como principais características os seguintes elementos:

- dados gráficos e alfanuméricos armazenados de forma integrada no banco de dados relacional, externo ao SIG;

- implementação de recursos de geoprocessamento (operadores espaciais, ferramentas de análise, etc.) apoiadas no gerenciador relacional, e apresentadas como extensões ou complementações ao modelo relacional;

- grande robustez de implementação, devido às garantias de integridade do esquema relacional;

- grande estabilidade, devido ao avançado grau de desenvolvimento dos SGBD relacionais.

\subsubsection{5 - SIG orientado a objeto}

Nesta concepção (figura 9), semelhante à anterior, é introduzido o conceito de objeto. Entende-se por objeto uma entidade que possui características gráficas, alfanuméricas e “comportamento” próprios. Nesta tecnologia o SIG é construído na concepção cliente servidor, onde os dados ficam baseados num computador e gerenciados pelo núcleo servidor. O usuário acessa a base de dados através do núcleo cliente. Esse acesso pode se dar de forma remota a partir de um outro computador, ligado ao primeiro, através de uma estrutura de rede.

É possível a conexão com um SGBDR externo, fazendo uma ligação entre os objetos da base do SIG e os dados mantidos na outra base. A integridade pode ficar comprometida se o acesso for feito de forma exclusiva ou no SIG ou no SGBDR, como ocorre no SIG relacional. 
A linguagem de programação nesta arquitetura geralmente é mais completa, dotada de todos os recursos necessários para fazer uso das vantagens de um modelo orientado a objeto, além de possibilitar a construção ou customização da interface gráfica. Para usuários experientes é possível também utilizá-la como uma interface de linha de comandos.

A utilização do conceito de objeto torna a arquitetura mais aberta, uma vez que as iniciativas no sentido de se estabelecer padrões de interoperabilidade são baseadas na padronização de objetos. Contudo Câmara (2001) argumenta que já foi demonstrado que é possível fazer o mesmo em relação a banco de dados relacionais.

As principais características nesta arquitetura, que tem o APIC e Smallworld como exemplos, são as seguintes:

- presença marcante de módulo de modelagem de dados, que dará personalidade às aplicações;

- possibilidade de conexão com gerenciador de bancos de dados relacional externo, mas a ênfase é no gerenciador de objetos, que geralmente é proprietário;

- tendência a um maior apoio em padrões, sistemas abertos e filosofia clienteservidor.

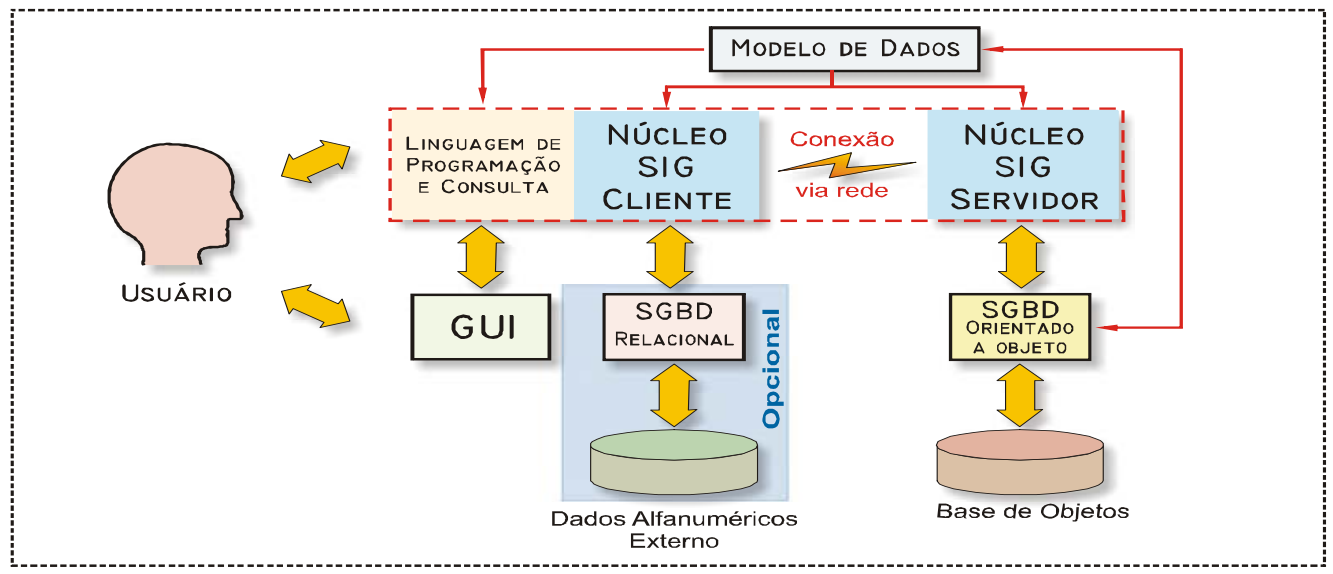

Figura 9 - SIG baseado em objetos (adaptado de Câmara, 2001). 


\subsubsection{6 - Desktop mapping}

Este tipo de solução procura facilitar as atividades de apresentação das informações sob formato de mapa, para o usuário final, que precisa elaborar um relatório ou fazer uma análise rápida. Normalmente de concepção simples, não tem a capacidade de gerenciar grande volume de dados, utilizando diretamente os arquivos gráficos e alfanuméricos de outros aplicativos, como: AutoCad, Excell, Acess, Dbase, entre outros. Desenvolvidos em ambiente windows, esses programas de custo relativamente baixo, têm incorporado tantas funções, inclusive indexação espacial, que segundo Câmara (2001), alguns estão se intitulando de desktop SIG.

A interface com o usuário é feita através de uma linguagem bastante simples, do tipo Visual Basic, que permite a criação de alguns tipos de funções e aplicações limitadas.

O relacionamento com outros aplicativos geralmente é conseguido com a utilização dos recursos mais comuns do Windows, como: OLE (Object Linking and Embedding), DDE (Dynamic Data Exchange) e ODBC (Open Database Conectivity) que são comandos do tipo copiar (Ctrl C) e colar (Ctrl V).

A arquitetura dessa classe de aplicativos pode ser vista na figura 10.

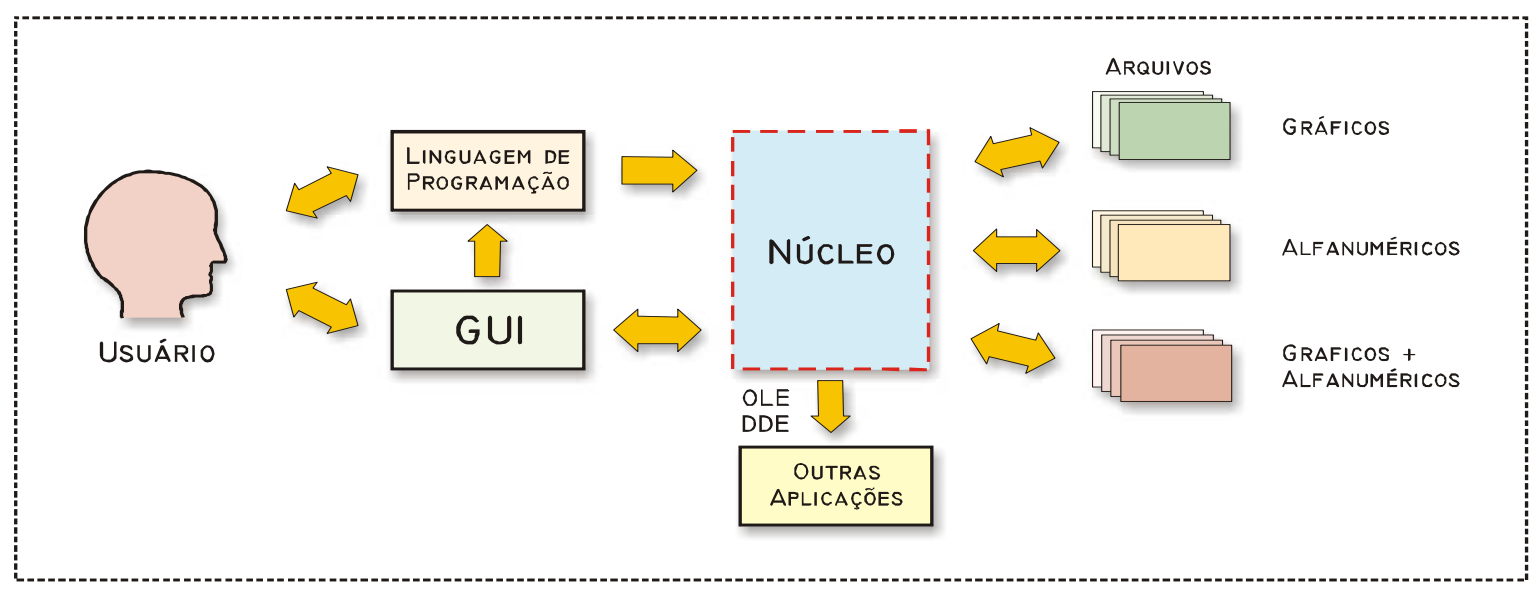

Figura 10 - Arquitetura das soluções desktop mapping (adaptada de Câmara, 2001). 
As principais características dessa solução, que tem o MapInfo e o Maptitude como seus representantes, são as seguintes:

- geralmente baseada em micro, em ambiente Windows, concentra esforços em uma boa interface de usuário e em recursos para produção de mapas para apresentação;

- funciona utilizando arquivos externos, desestruturados e independentes;

- não possui um forte gerenciador de informações gráficas ou alfanuméricas, mas pode, em geral, comunicar-se com gerenciadores existentes.

\subsubsection{7 - SIG baseado em imagens}

Câmara (2001) afirma que "esta é uma classe de aplicações em que o verdadeiro 'banco de dados' está na imagem e seus atributos. Assim, não existe um SGBD propriamente dito, apenas um conjunto de arquivos de imagem, codificados de maneira conveniente, tanto em termos de ocupação de espaço em disco, quanto em termos de facilidades de recuperação”.

Um arquivo do tipo imagem é formado por uma matriz de pontos (linhas e colunas), onde cada um deles pode assumir uma tonalidade diferente, variando do branco até o preto. A visualização desse conjunto de pontos é que dá a idéia de continuidade nas diversas feições da imagem. Deste modo, não é possível associar as informações alfanuméricas diretamente, já que as diversas feições, são formadas por um conjunto de pontos independentes. A solução usual é criar objetos vetoriais do tipo áreas, linhas e pontos, demarcando as feições, que podem ou não aparecer sobrepostos à imagem. A ligação do arquivo alfanumérico é feita através de centróides - referências gráficas que estabelecem a ligação entre os arquivos imagem e alfanumérico. Em outras palavras, centróides são pontos no arquivo vetorial que servem como endereços para que se possa associar os dados alfanuméricos à feição. 
Estes sistemas possuem interface gráfica para comunicação com o núcleo do SIG e, podem ou não, dispor de uma linguagem de programação. O ponto forte nesta concepção, está no processamento digital das imagens.

Suas principais características são:

- informações gráficas geralmente armazenadas como arquivos independentes, devido aos grandes volumes;

- comunicação com um banco de dados relacional externo por meio de "vetores" que são definidos sobre a imagem.

O SPANS, IDRISI e ERDAS são exemplos dessa arquitetura que pode ser observada na figura 11.

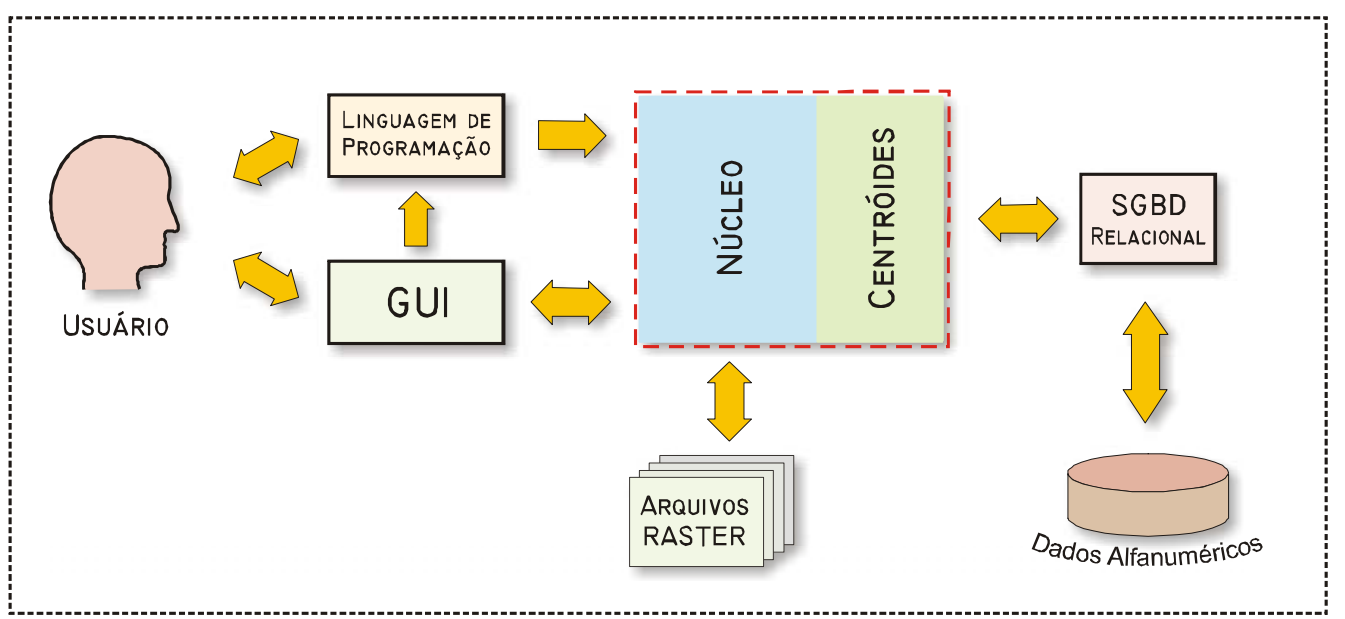

Figura 11 - Arquitetura de SIG baseado em imagem (adaptada de Câmara, 2001).

\subsubsection{8 - SIG integrado (matrizes-vetores)}

Com o aumento das preocupações relativas às questões ambientais, a integração entre dados matriciais (imagens), vetoriais e alfanuméricos tornou-se crucial, pela facilidade que essa ferramenta proporciona nas análises e nas tomadas de decisão. Ocorre 
que o tamanho dos arquivos matriciais exige muito espaço de armazenamento e os SGBDs do mercado ainda não possuem suporte para tratar eficientemente este tipo de arquivo. Assim, a solução adotada tem sido a da arquitetura dual adaptada para incluir o gerenciamento dos arquivos matriciais (figura 12). Os programas SPRING e ARC/VIEW (com extensões Spatial Analyst e Image Extension) são representantes dessa categoria de SIG.

Suas principais características são:

- gerenciamento em separado de dados gráficos e tabelas;

- armazenamento de gráficos em estruturas proprietárias;

- armazenamento de dados alfanuméricos em banco de dados relacional;

- capacidade de processar dados vetoriais, grades e imagens.

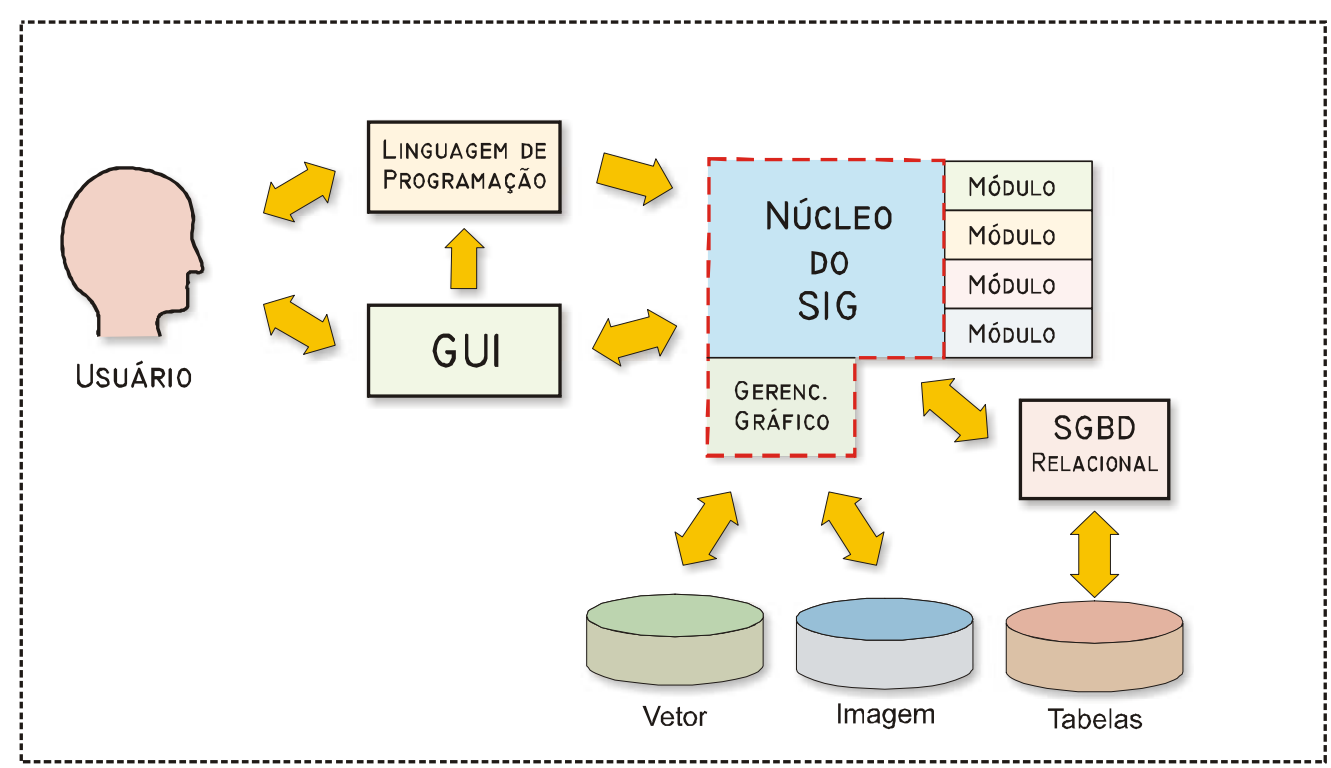

Figura 12 - Arquitetura de SIG integrado (adaptada de Câmara, 2001). 


\subsubsection{9 - Acesso a dados via Internet.}

A crescente expansão da rede Internet e a conseqüente demanda por informações, estão levando as linhas de pesquisa da área do geoprocessamento a procurar soluções de como disponibilizar dados geográficos na rede, embora ainda apresentem problemas em sua execução.

Uma das soluções bastante utilizada é aquela onde o usuário se comunica através de um browser (programa de navegação na Internet, tipo Windows Explorer, Netscape, p.ex.) com um servidor de Internet (computador onde os dados do SIG estão armazenados) para solicitar informações de uma região de interesse. Após o preenchimento de um formulário onde são especificados quais os tipo de dados que se deseja, é gerado o mapa em formato imagem, que é transmitido em uma página do tipo web, criada instantaneamente. Este tipo de solução apresenta alguns inconvenientes, como: a transmissão da imagem via rede, o que pode ser demorado além de sobrecarregar a rede; a falta de interatividade entre o usuário e o mapa apresentado, já que este é um produto estático; e, a sobrecarga do servidor que precisa construir o mapa através dos dados, geralmente vetoriais, e transmití-lo ao usuário. Toda operação simples, como a aproximação de um detalhe no mapa (zoom), obriga a geração de um novo mapa.

Outra solução é aquela onde o usuário, ao invés de preencher um formulário, tem acesso a um mapa índice. Nesta alternativa o usuário solicita a informação diretamente sobre o mapa com o auxílio do mouse, contudo os problemas de transmissão dos dados continuam os mesmos.

Câmara (2001) comenta que a transmissão de objetos geográficos em formato vetorial é mais interessante por possibilitar ao usuário uma interatividade maior, decidindo não só a região, mas também quais camadas de informações ativar. Esta alternativa apresenta um problema com relação aos browser atuais, que não estão preparados para a transmissão desse tipo de dado. Então os desenvolvedores estão utilizando duas soluções: 
- disponibilizar um plug-in- programa a ser instalado no computador do usuário, que trabalha associado ao browser, reconhece os dados vetoriais na medida em que eles chegam, e os exibe na tela do computador.

- criar um aplicativo em Java (linguagem de programação bastante utilizada na Internet) - transmitido e executado na máquina do usuário no momento da solicitação.

A primeira solução, embora bastante utilizada, apresenta o inconveniente de se ter de buscar o plug-in na página da Internet (site) do desenvolvedor e instalá-lo no computador. Como este programa trabalha associado ao browser e este sofre constantes atualizações, de tempos em tempos o usuário tem que fazer atualizações. A segunda solução é mais interessante, uma vez que não exige a instalação de programas e ao ser desativada desaparece do computador do usuário.

Apesar dos problemas, a transmissão de objetos geográficos é mais interessante que o de imagem porque possibilita a aplicação do conceito de hipermapa onde o usuário, ao selecionar um objeto no mapa, pode ter acesso às informações alfanuméricas associadas.

\section{4 - Funcionamento de um SIG.}

Originalmente os SIG foram projetados para resolver problemas específicos. No início, as instituições os desenvolviam baseados nas suas necessidades imediatas. Posteriormente, com a evolução dos processadores e a redução dos custos envolvidos, os SIGs tornaram-se uma ferramenta de uso mais amplo.

A necessidade em ampliar as aplicações fez com que vários desenvolvedores se debruçassem sobre o problema, gerando diferenças que redundam em pontos fracos ou fortes, dependendo da concepção adotada. Todavia existem funções que são características e são encontradas em qualquer programa, variando apenas o grau de confiabilidade e a 
qualidade da implementação. A existência destes recursos é, na maioria das vezes, suficiente para garantir o sucesso da maior parte das aplicações.

Segundo Câmara (2001), “em geral qualquer SIG é capaz de:

- representar graficamente informações de natureza espacial, associando a estes gráficos informações alfanuméricas tradicionais. Representar informações gráficas sob a forma de vetores (pontos, linhas e polígonos) e/ou imagens digitais (matrizes de pixels);

- recuperar informações com base em critérios alfanuméricos, à semelhança de um sistema de gerenciamento de banco de dados tradicional, e com base em relações espaciais topológicas, tais como continência, adjacência e interceptação;

- realizar operações de aritmética de polígonos, tais como: união, intersecção e diferença. Gerar polígonos paralelos (buffers) ao redor de elementos ponto, linha e polígono;

- limitar o acesso e controlar a entrada de dados através de um modelo de dados, previamente construído;

- oferecer recursos para a visualização dos dados geográficos na tela do computador, utilizando para isto uma variedade de cores;

- interagir com o usuário através de uma interface amigável, geralmente gráfica;

- recuperar de forma ágil as informações geográficas, com o uso de algoritmos de indexação espacial;

- possibilitar a importação e exportação de dados para outros sistemas semelhantes, ou para outros softwares gráficos;

- oferecer recursos para a entrada e manutenção de dados, utilizando equipamentos como mouse, mesa digitalizadora e scanner; 
- oferecer recursos para a composição de saídas e geração de resultados sob a forma de mapas, gráficos e tabelas, para uma variedade de dispositivos, como impressoras e plotters;

- oferecer recursos para o desenvolvimento de aplicativos específicos, de acordo com as necessidades do usuário, utilizando para isto alguma linguagem de programação, inclusive possibilitando a customização da interface do GIS com o usuário.

Todos estes recursos podem ser agrupados em categorias, para facilitar a comparação entre diferentes sistemas. Estas categorias básicas são: entrada de dados, gerenciamento de informações, recuperação de informações, manipulação e análise, e exibição e produção de saídas”.

\subsection{1 - Entrada de dados}

Os SIGs têm a capacidade de armazenar informações variadas, tanto de natureza alfanumérica como gráfica (vetores e imagens). Esta característica faz com que o sistema necessite de módulos ou interfaces que permitam ao usuário incorporar dados e visualizálos graficamente. É necessário ainda que o sistema detecte falhas ou incorreções nos dados no momento da entrada, avisando ao usuário antes de serem definitivamente incorporados ao banco de dados geográficos. Conforme Câmara (2001), um SIG precisa ser capaz de:

- permitir a digitalização de dados gráficos em formato vetorial, provendo os meios para associação (ou digitação) das informações alfanuméricas correspondentes. Isto é conseguido com a utilização de dispositivos de entrada de dados, como mesas digitalizadoras, mouse, teclado (digitação de coordenadas) entre outros;

- permitir a associação de imagens digitais ao banco de dados, através de recursos de georreferenciamento de imagens ou mesmo através da integração da imagem ao banco. Deste modo o sistema precisa ser capaz de converter ou traduzir arquivos de imagem codificados em diversos formatos distintos para o formato adotado por ele; 
- realizar análises de consistência sobre os dados vetoriais, visando detectar incorreções na topologia ou inconsistências com relação ao modelo de dados. Estas incorreções incluem: erros de fechamento topológico (elementos poligonais), superposições indesejáveis, undershoots, overshoots $^{2}$ por exemplo;

- realizar procedimentos de “limpeza” ou correção sobre os dados adquiridos, visando melhorar sua qualidade e prepará-los para a incorporação ao banco de dados geográfico. Estes procedimentos incluem edge matching ${ }^{3}$, eliminação de vértices desnecessários, suavização de curvas;

- receber, converter e tratar dados provenientes de outros sistemas de informação, geográficos ou não, gráficos ou não, a partir de arquivos de formato padronizado.

Segundo o mesmo autor, a entrada de dados é a atividade de implantação de SIGs que demanda maior tempo e recursos. Pode, em alguns casos, inviabilizar a sua adoção por organizações potencialmente usuárias. Dentro desta perspectiva, um fator importante que deve ser considerado é o grau de automação dessa entrada. Normalmente os processos manuais são mais sujeitos a erros, e as correções destes, de forma automática, é lenta e de custo elevado. A tendência atual é de se desenvolver procedimentos que automatizem ao máximo essa entrada de dados. Por exemplo, com a evolução dos processadores e dos programas de computador (hardware e software) a substituição da digitalização de mapas, através de mesas digitalizadoras, por rasterização e posterior digitalização semi-automática e automática tem se tornado bastante interessante.

2 Undershoots, overshoots - fechamento imperfeito de polígonos de modo que haja superposição ou falta de contigüidade entre polígonos adjacentes.

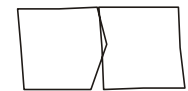

3 edge matching - falta de continuidade de uma feição, ou deslocamento dela em cartas (mapas) subseqüentes.

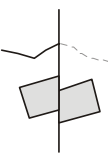




\subsection{2 - Gerenciamento e recuperação de informações}

Após a construção da base de dados geográficos o SIG precisa ser capaz de gerenciá-la de forma a poder (CÂMARA, 2001):

- manter a consistência da base de dados através das operações realizadas pelos usuários;

- controlar o acesso concorrente (simultâneo) aos dados por diversos usuários;

- garantir a integridade da relação gráfico-alfa;

- executar operações de backup e recuperação de informações;

- garantir a recuperação total ou parcial do banco em caso de falhas;

- garantir a segurança no acesso às informações contidas no banco, impedindo acessos não autorizados e limitando o acesso a dados sensíveis.

Normalmente as tarefas acima descritas são implementadas em sistemas gerenciadores de banco de dados profissionais. A diferença do SIG está na complexidade adicional da existência de dados gráficos e na garantia da sua integridade com os dados alfanuméricos. O acesso às informações deve ser eficiente e rápido, e isto pode ser alcançado com técnicas que incluem a indexação espacial, que as organiza por proximidade geográfica. Recursos que facilitem a formulação de consultas por parte do usuário são necessários. Linguagens de consulta como o SQL (Structured Query Language) são implementadas com comandos e operadores de natureza espacial e recursos de interface gráfica com o usuário, evitando a necessidade da memorização de seqüências de comandos e/ou o domínio da sintaxe de uma linguagem complexa. 


\subsection{3 - Manipulação e análise}

Pode-se agrupar as funções de manipulação e análise de dados geográficos de acordo com a natureza do dado tratado. Seguindo essa premissa, elas podem ser agrupadas em funções de análise geográfica, de processamento de imagens, de modelagem de terreno, de geodésia e fotogrametria, de redes e de produção cartográfica.

As funções restritas à análise geográfica permitem a combinação de informações temáticas, tanto de domínio vetorial como de domínio matricial. Um conjunto importante de procedimentos de análise geográfica foi definido por Tomlin (1990) apud Câmara (2001) e foi denominado “Álgebra de Mapas”. Estas definições são a base de implementações de operadores de análise em diferentes sistemas e incluem:

- reclassificação;

- intersecção (“overlay”);

- operações boleanas e matemáticas entre mapas; e

- consulta ao banco de dados.

As funções de processamento digital de imagens envolvem o tratamento das imagens provenientes de satélite e as obtidas por scanners. Entre as funções necessárias podem ser elencadas as de:

- realce por modificação de histograma;

- filtragem espacial;

- classificação estatística por máxima verossimilhança;

- rotação espectral (componentes principais);

- transformação IHS-RGB;

- registro. 
A Modelagem Numérica do Terreno (MNT) é uma técnica que, a partir de uma mostra discreta de pontos com as coordenadas planas e altimétricas conhecidas, gera uma superfície matemática que procura modelar as irregularidades topográficas da região da qual os pontos fazem parte. A partir dessa superfície é possível o cálculo da declividade, do volume, a elaboração de cortes transversais, e de linhas de visadas. Este processo, que é fundamental para aplicações de engenharia, precisa de funções que basicamente sejam capazes de:

- determinar o modelo ( grade regular ou triangular) a partir de pontos esparsos ou linhas;

- gerar mapas de contorno (isolinhas);

- gerar mapas de declividade e de aspecto;

- visualizar em 3D (com imagens e temas);

- cálcular volumes; e

- analisar perfis.

As funções de geodésia e fotogrametria permitem a realização de procedimentos de restituição e ortoretificação digital. Estes processos são fundamentais em aplicações de cartografia automatizada e atualização de mapeamentos.

As funções de modelagem de redes são aquelas que permitem ao usuário simular determinadas condições e estudar qual será o efeito sobre um determinado sistema. Num sistema telefônico, por exemplo, pode-se precisar saber quantas linhas telefônicas estão ligadas a uma determinada caixa terminal, ou, num sistema de águas, qual o efeito nas diversas casas se for alterada a quantidade de cloro na subestação fornecedora. Ambos os questionamentos têm modelagens diferentes no sistema de redes. Normalmente, os programas comerciais dispõem somente das funções de cálculo do melhor caminho e do caminho crítico, o que é insuficiente para a maioria das aplicações. Para atender às diferentes necessidades das aplicações de rede, os programas de SIG devem ser versáteis, maleáveis e adaptáveis, havendo a necessidade de uma ligação com o banco de dados, onde as informações descritivas estão armazenadas. Especificamente, é na área de redes que o uso de soluções mais modernas como SGBDs orientados a objetos está se impondo. 


\subsection{4 - Exibição e produção cartográfica}

Com relação à saída de dados, os SIGs tendem a priorizar ou os recursos de produção, com ênfase na produção automatizada de mapas, tabelas e relatórios, ou os recursos de consulta onde o interesse gira em torno da resposta interativa do sistema às demandas do usuário.

No caso de impressão, alguns SIGs dispõem de ferramentas para produção de cartas, com recursos muitas vezes altamente sofisticados de apresentação gráfica. Essas ferramentas permitem a definição interativa de uma área de impressão, a colocação de legendas, textos explicativos e notas de crédito. Uma biblioteca de símbolos é também atributo fundamental de um sistema de produção. Os pacotes mais sofisticados dispõem de controladores para dispositivos de gravação eletrônica a laser, o que assegura a produção de mapas de alta qualidade.

\section{5 - Critérios para a escolha de um SIG}

De um modo geral, os programas direcionados para SIG foram originalmente projetados para resolver um conjunto específico de problemas em geoprocessamento. Esta vocação original dos softwares gerou diferenças na concepção, de modo que não existem no mercado programas totalmente adequados para aplicações específicas. Todos têm pontos fortes e fracos e, nem sempre, correspondem perfeitamente aos objetivos para os quais foram projetados.

Um modo de se proceder é envidar esforços no sentido de identificar as necessidades e ir graduando sua importância para a aplicação. Obviamente não se deve esperar que um SIG comercial preencha completamente as necessidades, e esta visão sobre o fato, possibilita que se utilizem critérios mais flexíveis para a escolha. 
Segundo Câmara (2001), as características que devem ser investigadas em cada software candidato, de acordo com o interesse, e para testar sua adequação às necessidades do projeto, incluem:

- possibilidades de customização da interface com o usuário (redefinição da estrutura de menus e diálogos; inclusão de funções desenvolvidas pelo usuário);

- flexibilidade da modelagem de dados;

- existência ou não de linguagem de programação para desenvolvimento de aplicativos; complexidade e completeza da linguagem de programação;

- existência ou não de versão em português; disponibilidade de documentação e/ou material de treinamento em português;

- armazenamento dos dados em base de dados geográfica contínua ou necessidade de fracionamento em mapas;

- existência ou não de restrições e controles de integridade na conexão gráfico-alfa;

- existência ou não de sistemas de indexação espacial para recuperação rápida de informações gráficas;

- disponibilidade de aplicações prontas, desenvolvidas por terceiros, na área de interesse do projeto;

- capacidade de importação e exportação de dados;

- possibilidade de operação em redes heterogêneas de equipamentos (utilização simultânea de equipamentos de diversos fabricantes);

- capacidade de produção de saídas: mapas, cartas, mapas temáticos, gráficos, relatórios, etc;

- recursos para conversão de dados;

- capacidade de operação simultânea por diversos usuários; 
- aderência a padrões de fato ou de direito, principalmente nas áreas de bancos de dados e intercâmbio de informações;

- recursos de gerenciamento de backups e recuperação de dados;

- existência ou não de linguagem de consulta à base gráfica/alfanumérica;

- recursos de processamento de polígonos (operações de união, intersecção, etc.);

- recursos de detecção e correção de falhas nos dados gráficos (edge-matching, eliminação de undershoots e overshoots, etc.);

- variedade de tipos de dispositivos de saída (plotters e impressoras) e de entrada (scanners, mesas digitalizadoras, etc.);

- confiabilidade comercial e técnica do representante e sua equipe de suporte.

\section{6 - Desenvolvimento de SIG - tendências}

Desde as primeiras concepções sobre SIG, na medida em que aspectos relativos a hardware e software evoluíam, os desenvolvedores ao longo dos anos seguiam determinadas tendências. No entanto, segundo Câmara (2001) "nos últimos anos, algumas tendências parecem ser definitivas”. Dentre essas preferências pode-se citar as seguintes:

- aplicativos de baixo custo - tendo como premissa a popularização do uso da ferramenta dentro de organizações, tem-se direcionado esforços no sentido de se oferecer alternativas bastante simplificadas e baratas. O uso dessas alternativas associadas a microcomputadores ligados através de redes a servidores de dados espaciais mais poderosos, tem-se mostrado uma alternativa atraente;

- uso de imagens - com a redução dos custos de processamento e armazenamento de grandes volumes de dados, provocados pela evolução dos equipamentos, o uso de imagens raster (matriciais) como complementar à informação vetorial, tem-se intensificado. Há uma forte probabilidade do aumento do uso de ortofotos digitais e de imagens de satélite, principalmente as de alta resolução geométrica; 
- orientação a objetos - banco de dados orientados a objeto é uma tendência mundial em termos de programação e desenvolvimento de sistemas. Um objeto na linguagem de banco de dados pode ser entendido como uma entidade, real ou abstrata, que possui uma série de atributos que o caracterizam. Neste contexto, o objeto é tratado como tendo existência própria, e as operações se processam sobre ele e não sobre cada atributo individualmente. Segundo Câmara (2001), “os conceitos de orientação a objetos, aplicados à área de bancos de dados, levam à definição mais racional, mais próxima do mundo real, de modelos e estruturas de dados. Isto é especialmente benéfico no caso dos SIG, uma vez que as informações que manipulam, devido às suas características espaciais, são difíceis de modelar utilizando as técnicas tradicionais. Modelos de dados geográficos são mais intuitivos para o analista e para o usuário, e seu uso ajudará a reduzir o tempo de desenvolvimento de aplicativos geográficos”;

- intercâmbio de dados geográficos - padronização - a existência de diversas soluções em SIG tem possibilitado que cada organização adote aquela que melhor atenda suas necessidades. A falta de uma padronização tem causado alguns transtornos na hora se tentar compartilhar os dados geográficos de organizações distintas. Algumas soluções têm sido propostas, mas ainda exige algum tempo para que o problema seja resolvido;

- acesso aos dados geográficos na Internet - com a popularização da Internet, muitos organismos tem procurado disponibilizar seus dados através dessa tecnologia. Para atender essa tendência os desenvolvedores tem trabalhado no sentido de tornar o acesso mais eficiente. Várias soluções têm sido propostas, como as que foram mencionadas no item 1.3.1.9, deste trabalho. 


\section{7 - Sistemas Gerenciadores de Banco de Dados}

De maneira geral, entende-se por banco de dados um conjunto de informações relacionadas entre si, referentes a um mesmo assunto e organizadas de maneira útil, com o propósito de servir de base para que o usuário recupere informações, tire conclusões e tome decisões. Na linguagem dos especialistas a definição, na verdade, se restringe à estrutura de organização e relacionamento desses dados. Por este prisma, o Sistema Gerenciador de Bases de Dados (SGBD) trata de duas espécies de informações: as que descrevem as entidades e as que informam como essas entidades se relacionam.

Um relacionamento é uma associação entre entidades ou objetos com um significado. Se um sítio arqueológico for tratado como um objeto e for estabelecido o relacionamento entre apenas dois sítios, esta relação é classificada como 1:1 (um para um). No entanto, se a relação for entre o sítio e os diversos componentes que o caracterizam (artefatos, marcas de implantação, datação, entre outros), a classificação passa a ser de 1:n (um para vários). Finalmente, se o relacionamento estabelecido for entre os elementos característicos de diversos sítios, a relação agora é de n:m (vários para vários).

Os SGBDs estabelecem esses relacionamentos através dos conceitos de item, registro, arquivo e elo. O item é a unidade de informação que pode ser um número inteiro ou uma cadeia de caracteres de um determinado comprimento, por exemplo. A seqüência desses itens pode ser associada a um registro, e um conjunto de registro pode formar um arquivo. Segundo Furtado (1988) "é natural fazer corresponder um conjunto de entidades a um arquivo”. Então, por exemplo, num arquivo denominado sítio, cada sítio corresponde a um registro e o tipo de material arqueológico encontrado, associado aos elementos que caracterizam o contexto de ambientação, são os itens.

O elo é a ligação entre dois registros pertencentes a um mesmo arquivo ou a arquivos diferentes. Os elos podem ser explícitos, quando estabelecem a ligação efetiva entre os registro, e implícitos quando um item ou seqüência de itens possuem valores 
comparáveis aos de outro registro. Por exemplo, pode-se pensar em comparar as características da cerâmica de um sítio com as de outro.

A partir do tipo de elo que o banco de dados utiliza pode-se classificá-lo em:

- Hierárquico - nesta estrutura o elo entre registros é do tipo explícito. Trabalha-se com dois tipos de registros, um denominado de "pai” ou principal, e outro denominado “filho" ou detalhado. Ao registro "pai” estão associados vários registros “filhos” e a cada um dos “filhos”, podem ser associados outros e assim, sucessivamente. A característica principal deste modelo é que os registros têm sempre um de nível mais alto associado a eles. A vantagem desta organização está no fato de permitir um conjunto múltiplo de combinações dos atributos a serem associados com qualquer registro dado, sem armazenar dados repetitivos. É o tipo de estrutura de 1:n (um para vários) ou estrutura de árvore (figura 13).

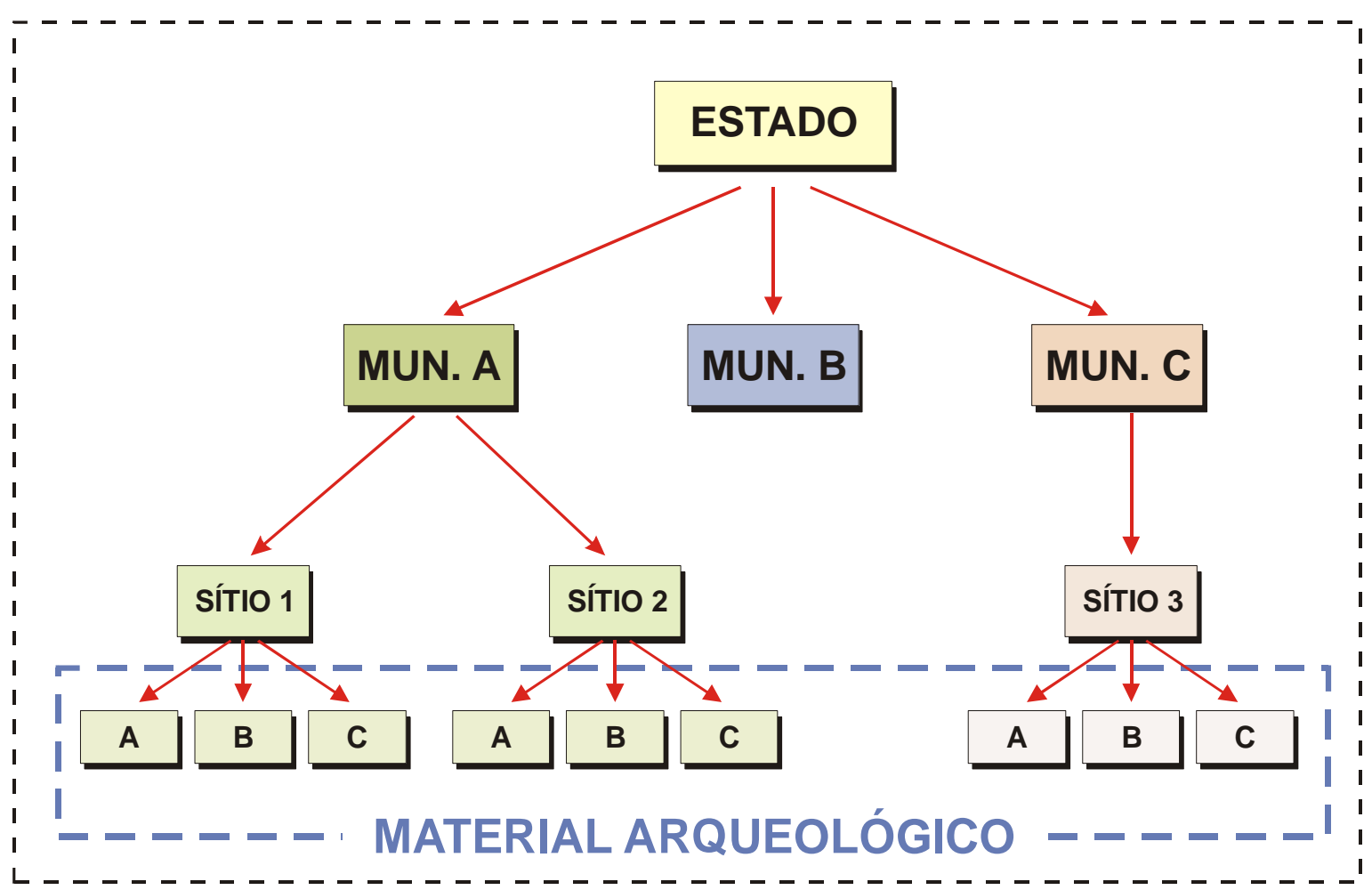

Figura 13 - Modelo hierárquico. 
- Redes - neste modelo todos os elos são do tipo explícito e o relacionamento pode ser feito entre quaisquer registros. A idéia de registros “filhos” ligados a um "pai” deixa de fazer sentido. É o tipo de relação de muitos para muitos (n:m). Esse modelo foi desenvolvido em meados da década de 60, como parte do trabalho da CODASYL ( Conference on Data Systems Language) com o objetivo de separar a estrutura de dados do armazenamento físico dos dados, eliminando a duplicação e a necessidade de dados que impliquem em erros e custos (figura 14).

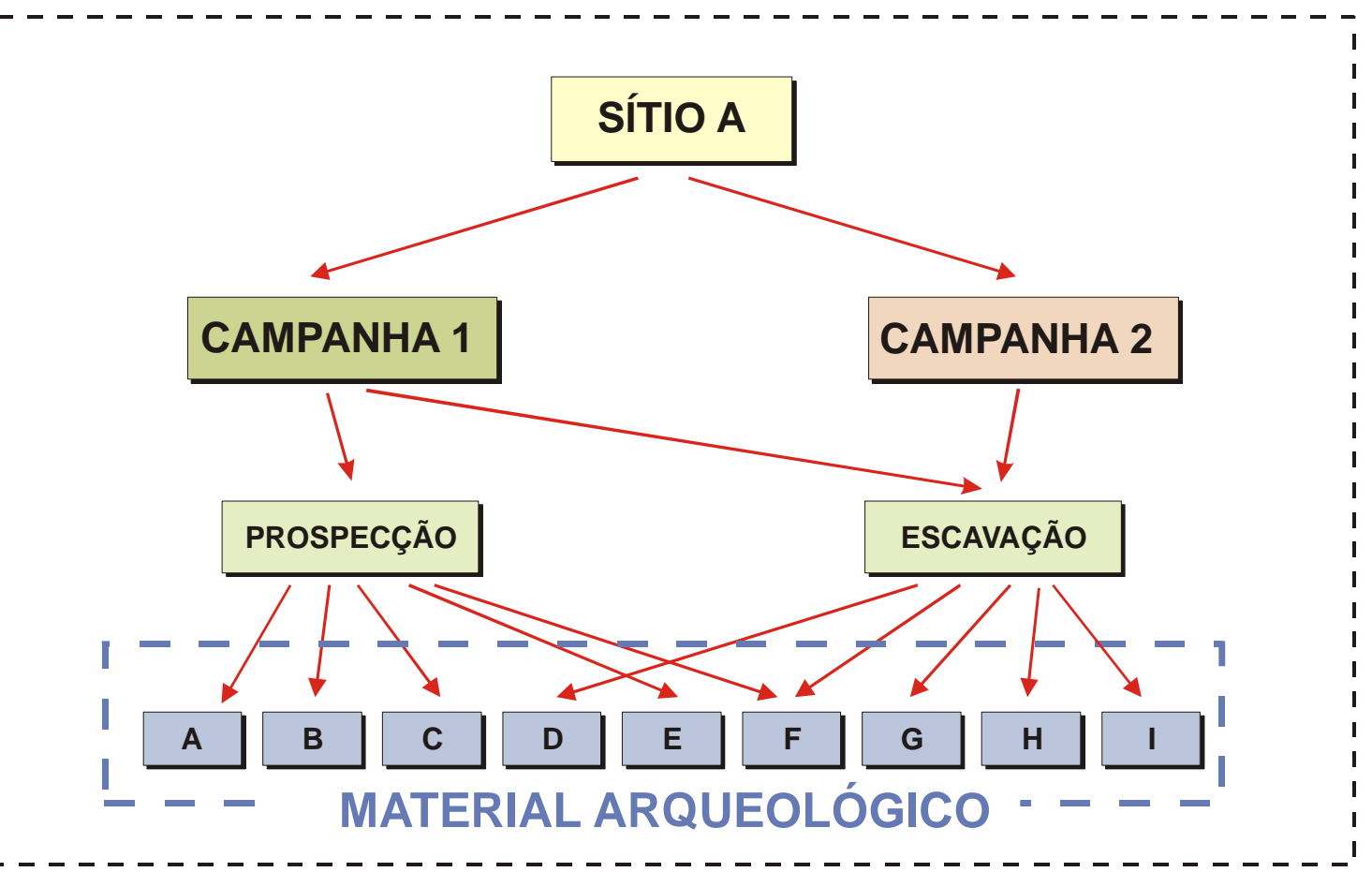

Figura 14 - Modelo de rede.

- Relacional - quando o elo é do tipo implícito e os dados são organizados em forma de tabelas. O relacionamento se dá através de código de ligação (elos) entre as diversas tabelas ou simplesmente através dos registros armazenados em campos comuns de tabelas distintas. Este tipo de solução permite que sejam geradas novas tabelas apenas pela associação de outras. Por exemplo, é possível associar a tabela de dados geográficos com a dos sítios arqueológicos e com a de tipo de material 
arqueológico encontrado, para gerar uma nova onde apareça o nome do sítio, sua sigla , município, região arqueológica e tipo de material (figura 14).

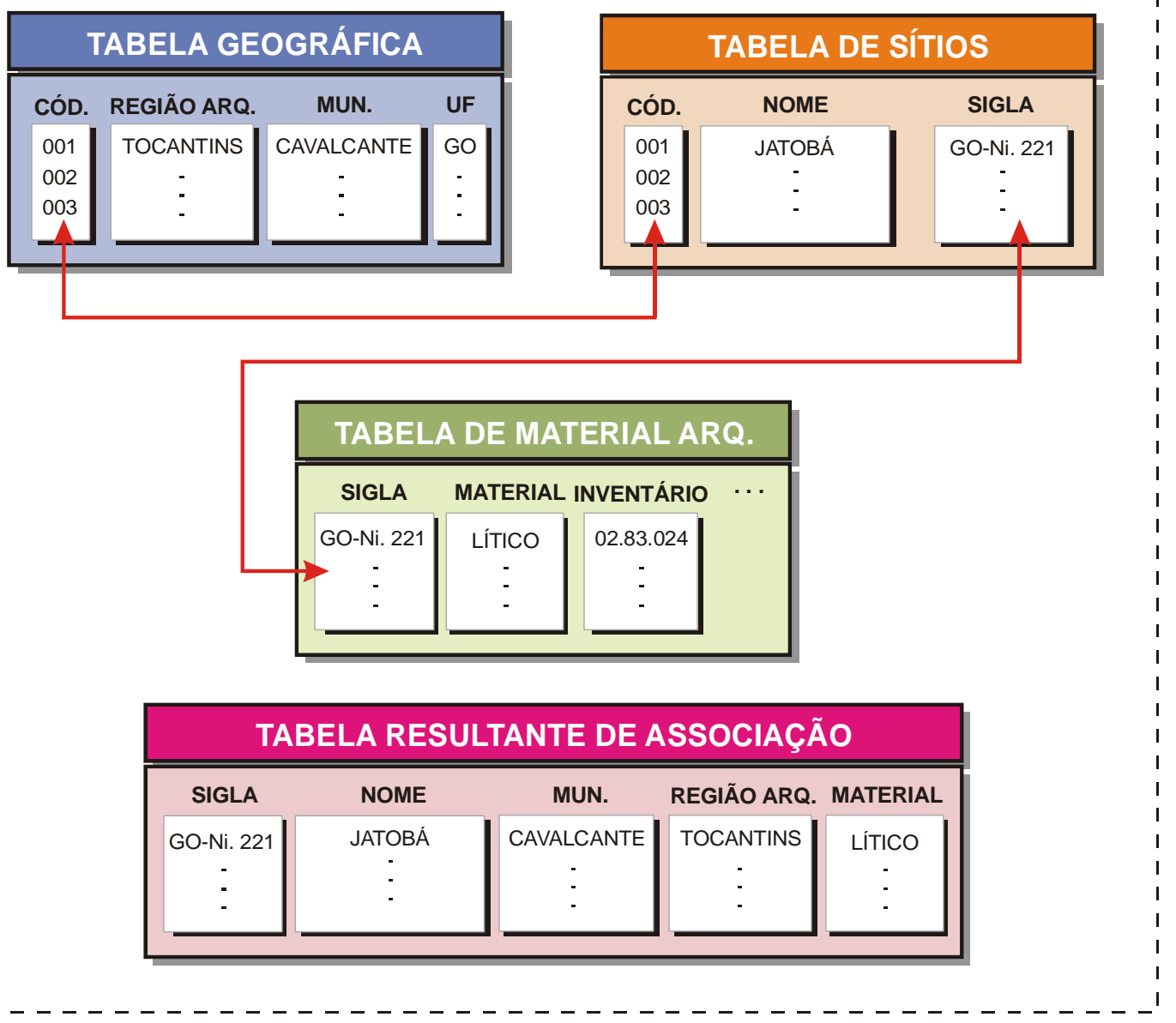

Figura 15 - Modelo relacional.

Dependendo do que se pretende fazer, a estrutura hierárquica é mais adequada, principalmente quando os dados apresentam uma certa concatenação (país, estado, município, sítio arqueológico), contudo, para outras situações, o ideal pode ser a relacional ou talvez, a estrutura de rede. Na verdade, quando se planeja a arquitetura de um SGBD é possível deparar com situações onde seja necessária a adoção de uma solução mista, onde as três estruturas estão presentes. 


\section{Capítulo II - SIG aplicado à arqueologia. Uma análise crítica}

A idéia de se poder, a partir de um conjunto de dados georreferenciados, tomar decisões acertadas num curto espaço de tempo, foi sempre o desejo do homem. $\mathrm{O}$ obstáculo principal residia no complexo número de variáveis que se tem de cruzar e confrontar. Atualmente, devido ao grande avanço na capacidade de processamento dos computadores, essa tarefa tem se tornado menos penosa.

Em arqueologia, principalmente quando se trabalha com a idéia de salvamento arqueológico, onde o fator tempo é importante, a questão fica mais premente. Neste caso, pode-se vislumbrar a aplicação de um SIG em dois momentos distintos. Num primeiro, quando se está na fase de reconhecimento geral, conforme Redman (1973), o SIG pode indicar os locais mais prováveis de se encontrar sítios arqueológicos na região estudada (Cartas de Potencial Arqueológico). Num segundo momento, quando todos os dados arqueológicos já foram coletados e estudados, o SIG entra como ferramenta de análise procurando através das diversas interações entre informações arqueológicas ou não, explicar aspectos relativos às populações humanas do passado e como elas ocuparam a região. Alguns trabalhos têm dirigido seus esforços em direção ao primeiro momento, e aparecem na literatura alguns trabalhos de cunho eminentemente teórico e até mesmo, como no caso de Thomaz (2002), de valor prático.

Do ponto de vista teórico, é perfeitamente possível se estruturar um sistema que modele com grande eficiência a área a ser percorrida, contudo as dificuldades se iniciam no momento de introduzir elementos fundamentais para formar a base cartográfica. Em grande parte do País, as cartas são antigas e em escala inadequada. Em contraposição, quando se tem cartografia em escala adequada, o volume de dados torna o processamento quase impossível em computadores comuns. Passa-se nesse instante, a depender de computadores com grande capacidade de processamento, as workstation. 
Um outro aspecto diz respeito à necessidade de se modelar o mundo real, que consiste em selecionar fenômenos e entidades de interesse (dados), abstraindo-os e generalizando-os. No entanto, diferentes conjuntos de fenômenos podem ser escolhidos para descrever distintas visões do mundo, para uma mesma região, em um dado instante, e nesse caso, qual das visões é a correta ?

Do ponto de vista da Arqueologia, a modelagem passa necessariamente pelo estudo das diversas interações que o homem do passado manteve com o ambiente. Para tanto é necessária a seleção de variáveis ambientais que representem essa interação, ou seja, quais dados são relevantes no estudo.

Costuma-se dividir as populações pré-históricas em dois grupos distintos: os caçadores-coletores, povos eminentemente nômades e os agricultores-ceramistas, povos mais sedentários. Cada um destes grupos tinha necessidades próprias e escolhia seus lugares de ocupação por óticas distintas, em consonância com os aspectos sócio-culturais. Esses aspectos fornecem indicadores dos locais onde existe a maior probabilidade de serem encontrados vestígios de ocupação. Em última instância, mostram os parâmetros locacionais de assentamento que reforçam um esquema preditivo de grande valia para o encaminhamento das etapas de reconhecimento geral e levantamento arqueológico.

Os parâmetros do modelo locacional, que permitem o mapeamento das áreas potencialmente favoráveis ao encontro de sítios arqueológicos, são fixados a partir de algumas situações de ordem universal, relativa aos padrões de assentamento, corroboradas por várias situações locais. Segundo Morais et al (1998), em uma primeira aproximação, os parâmetros podem ser subdivididos naqueles cuja função está ligada à moradia e naqueles onde ela está ligada a atividades extrativas (mineração e pesca). 
Dentro do primeiro grupo, encontram-se:

- Terraços fluviais - acumulações fluviais com superfície horizontal ou levemente inclinada, com diferentes graus de retrabalhameto, alçada por ruptura de declive em alguns metros acima do nível de base local, modelada pela erosão fluvial, ou as várzeas de sedimentação recente, suficientemente extensas para suportarem, no passado, assentamentos de grupos indígenas (mais freqüentemente caçadorescoletores e excepcionalmente agricultores.)

- Vertentes - planos de declive que enquadram os vales, com feições morfológicas e amplitude variada. As vertentes de declive suave (menos de $10 \%$ de declividade) eventualmente suportaram assentamentos de grupos indígenas, mais freqüentemente os agricultores.

- Patamares de vertentes - encostas com rupturas de declive horizontalizadas, normalmente situadas na meia encosta das vertentes. Eventualmente suportaram assentamentos de grupos indígenas caçadores-coletores ou agricultores.

- Cabeceiras de drenagem - planos de declive suave em anfiteatro, geralmente modelados por erosão regressiva, que enquadram nichos de nascentes (mananciais). No passado suportaram, com freqüência, assentamentos indígenas pré-coloniais.

- Topos de interflúvios - lineamentos ou espigões interpostos entre duas bacias hidrográficas, normalmente de topos semi-aplainados e vertentes de baixa declividade. Existem registros arqueológicos nos trechos mais rebaixados desses divisores de águas, confirmando que foram locais de passagem entre ambientes localmente distintos, envolvendo diferentes bacias hidrográficas.

- Escarpas - desníveis abruptos de subverticais a verticais, de origem tectônica ou erosiva, podendo conter abrigos ou grutas resultantes de desmoronamentos ou da dissolução de rochas carbonatadas, eventualmente suportando ambientes favoráveis à ocupação de grupos indígenas, mais freqüentemente caçadores coletores. 
No segundo grupo encontram-se :

- Cascalheiras - depósitos de seixos rolados, compondo litologias homogêneas ou diversificadas, acumuladas nos leitos ou nas margens, como elementos de porte utilizáveis no processo de lascamento para a obtenção de artefatos de pedra lascada. Inclui rochas de boa fratura conchoidal para o talhe, debitagem e retoque ou de dureza suficiente para a percussão.

- Pavimentos detríticos - depósitos de materiais grosseiros, de granulometria variada, resultante do intemperismo mecânico, pelo efeito de termoclastia, dispostos em vertentes nos topos semiplanos de morros, ou acumulados nas partes basais de declives, como elementos utilizáveis no processo de lascamento para a obtenção de artefatos de pedra. Inclui rochas de boa fratura conchoidal para o talhe, debitagem e retoque ou de dureza suficiente para a percussão ou textura adequada para o polimento.

- Barreiros - ocorrências inseridas em ambientes de acumulação flúvio-aluvial e nos terraços fluviais, de sedimentos argilo-silto-arenosos, formando pacotes de matéria-prima para o processamento e a produção de artefatos cerâmicos.

- Corredeiras, cachoeiras e saltos - desníveis gradativamente abruptos dos leitos fluviais, provocando quedas d'água que dificultam as migrações sazonais da ictiofauna, constituindo locais para fácil apanha de peixes migratórios.

Pela diversidade de ambientes existentes no País, alguns ajustes devem ser feitos nesses parâmetros, uma vez que aquilo que é um forte indicador em uma região do País, não o é em outra. 


\section{1 - SIG Arqueologia enquanto modelo teórico}

Um SIG é uma tecnologia interdisciplinar, que permite a convergência de diferentes conteúdos científicos para o estudo de fenômenos ambientais e urbanos. No entanto, segundo Câmara (2001), essa pretensa interdisciplinaridade esbarra num problema conceitual, o de transformar estes conteúdos em algoritmos e estruturas de dados utilizados para armazenamento e tratamento dos dados geográficos.

Para abordar o problema fundamental da geoinformação, Câmara (2001) adota o paradigma dos quatro universos proposto por Gomes e Velho (1995) que são:

- o universo do mundo real, que inclui as entidades da realidade a serem modeladas no sistema;

- o universo matemático (conceitual), que inclui uma definição matemática (formal) das entidades representadas;

- o universo de representação, onde as diversas entidades formais são mapeadas para representações geométricas e alfanuméricas no computador;

- o universo de implementação, onde as estruturas de dados e algoritmos são escolhidos baseados em considerações como desempenho, capacidade do equipamento e tamanho da massa de dados. É neste nível que acontece a codificação. 


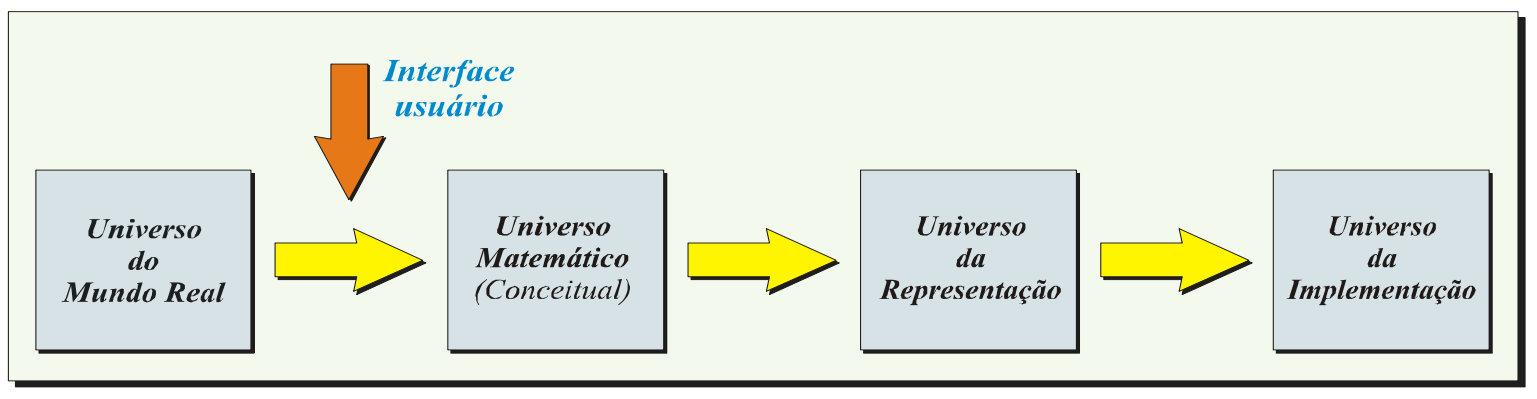

Figura 16 - O paradigma dos quatro universos proposto por Gomes e Velho(1995) apud Câmara (2001)

A concepção de um SIG aplicado às necessidades da arqueologia, deve abordar de forma apropriada esses quatro universos. De início, o pesquisador precisa selecionar quais as informações do mundo real são importantes. É neste momento que os dados referentes ao tipo de solo, à topografia local ou regional, à geofísica, ao clima e a vegetação entram em questão. Deve-se procurar entender como estes temas interferiram na ocupação da região estudada.

Em seguida, no modelo conceitual, deve-se abordar de que forma esses dados podem ser equacionados. Worboys (1995) apud Câmara (2001) afirma que o espaço geográfico pode ser modelado de duas formas complementares, os modelos de campos e os de objeto.

Segundo esse autor, o modelo de campos enxerga o espaço geográfico como uma superfície contínua, sobre a qual variam os fenômenos a serem observados segundo diferentes distribuições. Neste modo de representação, cada ponto do mapa está associado a um tipo específico de atributo. Num mapa geológico, por exemplo, cada ponto é caracterizado por um tipo de mineral. 
No modelo por objetos, o espaço geográfico é representado por uma coleção de entidades distintas e identificáveis. Deste modo, num mapa arqueológico, os sítios são tratados como objetos distintos com atributos próprios.

No universo da representação é definida qual a melhor forma de representação geométrica que pode ser associada ao modelo conceitual. A representação geométrica pode se dar de duas formas distintas, a vetorial e a matricial. Na representação vetorial, os elementos gráficos de um mapa são representados por pontos, linhas, polígonos ou áreas. Na representação matricial é gerada uma malha quadriculada regular formando células que recebem valores numéricos correspondentes ao tema estudado. É importante lembrar que a forma de representação está associada ao tipo de dado representado, ou seja:

- dados temáticos: admitem tanto representação matricial como vetorial;

- dados cadastrais: a parte gráfica é armazenada em forma de coordenadas vetoriais e seus atributos não gráficos são armazenados em bancos de dados;

- redes: a parte gráfica é armazenada em forma de coordenadas vetorias com topologia arco-nó e seus atributos não gráficos são guardados em banco de dados;

- imagens digitais : armazenadas em representação matricial;

- modelos numéricos de terreno (MNT): podem ser armazenados em grades regulares (representação matricial), grades triangulares (representação vetorial com topologia arco-nó) ou isolinhas ( representação vetorial sem topologia).

Um modelo numérico de terreno (MNT) também conhecido como modelo digital de terreno (MDT), segundo Câmara (2001), é uma representação matemática computacional da distribuição de uma fenômeno espacial que ocorre dentro de uma região da superfície terrestre. Esse fenômeno pode estar representando uma variação de altitude ou uma variável geofísica. Dependendo do caso, a representação matricial ou a vetorial pode ser adotada. Os MNTs também podem ser convertidos em mapas temáticos ou imagens. Em ambos os casos, a grandeza numérica é quantizada, seja por um número 
pequeno de valores (caso de dados temáticos), seja para a variação associada a imagens (valores discretos).

Tanto as representações vetoriais, como a matricial, apresentam vantagens e desvantagens dependendo do fenômeno geográfico que se pretende abordar. De Câmara (2001) foi extraída a tabela 1, a seguir, onde são apresentadas as vantagens e desvantagens em relação à representação de mapas temáticos.

Tabela 1 - Comparação entre representações para mapas temáticos (CÂMARA, 2001)

\begin{tabular}{|c|c|c|}
\hline \multirow{2}{*}{ ASPECTO } & \multicolumn{2}{|c|}{ Representação } \\
\hline & Vetorial & Matricial \\
\hline $\begin{array}{l}\text { Relações espaciais } \\
\text { entre objetos }\end{array}$ & $\begin{array}{l}\text { Relacionamentos topológicos entre } \\
\text { objetos disponíveis. }\end{array}$ & $\begin{array}{l}\text { Relacionamentos espaciais devem } \\
\text { ser inferidos. }\end{array}$ \\
\hline $\begin{array}{l}\text { Ligação com banco } \\
\text { de dados }\end{array}$ & $\begin{array}{l}\text { Facilita associar atributos e } \\
\text { elementos gráficos. }\end{array}$ & $\begin{array}{l}\text { Associa atributos apenas a classe } \\
\text { do mapa. }\end{array}$ \\
\hline $\begin{array}{c}\text { Análise, simulação e } \\
\text { modelagem }\end{array}$ & $\begin{array}{l}\text { Representação indireta de } \\
\text { fenômenos contínuos. } \\
\text { Álgebra de mapas é limitada. }\end{array}$ & $\begin{array}{l}\text { Representa melhor fenômenos } \\
\text { com variação contínua no espaço. } \\
\text { Simulação e modelagem mais } \\
\text { fáceis. }\end{array}$ \\
\hline Escalas de trabalho & $\begin{array}{l}\text { Adequado tanto a grandes quanto } \\
\text { pequenas escalas. }\end{array}$ & $\begin{array}{l}\text { Mais adequado para pequenas } \\
\text { escalas (1:25.000 e menores). }\end{array}$ \\
\hline Algoritmos & Problemas com erros geométricos. & $\begin{array}{l}\text { Processamento mais rápido e } \\
\text { eficiente. }\end{array}$ \\
\hline Armazenamento & Por coordenadas (mais eficiente). & Por matrizes. \\
\hline
\end{tabular}

Obs.: O formato mais vantajoso é apresentado em destaque. 
Com respeito ao modelo numérico de terreno (MNT), o mesmo autor apresenta a tabela 2, transcrita a seguir, onde são mostradas as vantagens e os problemas quando se adota a representação vetorial triangular ou a matricial.

Tabela 2 - Comparação entre grades regulares e triangulares para representar modelos numéricos de terreno (CÂMARA, 2001)

\begin{tabular}{|c|c|c|}
\hline & Malha triangular & Grade matricial \\
\hline \multirow{2}{*}{ Vantagens } & $\begin{array}{l}\text { Melhor representação de relevo } \\
\text { complexo. }\end{array}$ & Facilidade de manuseio e conversão \\
\hline & $\begin{array}{l}\text { Incorporação de restrições como } \\
\text { linhas de crista. }\end{array}$ & $\begin{array}{l}\text { Adequada para geofísica e } \\
\text { visualização 3D. }\end{array}$ \\
\hline \multirow{2}{*}{ Problemas } & Complexidade de manuseio & Representação de relevo complexo \\
\hline & Inadequada para visualizar 3D & Cálculo de declividade. \\
\hline
\end{tabular}

Finalmente, no universo de implementação, são escolhidas as estruturas de dados que serão utilizadas para construir o sistema. É neste momento que se define concretamente os caminhos da programação que podem admitir uma variação muito grande de soluções. Deve-se levar em conta as aplicações para as quais o sistema está voltado, a disponibilidade de algoritmos para tratamento de dados geográficos e o desempenho do hardware.

Câmara (2001) argumenta que o aspecto principal neste momento é usar estruturas de indexação espacial, compostas de dados e algoritmos de pesquisa e recuperação. Esta providência será fato determinante no desempenho total do sistema. 


\section{2 - O problema na geração da base cartográfica}

A cartografia sistemática brasileira adota a mesma articulação da Carta do Mundo ao Milionésimo, a qual divide a Terra em fusos de $6^{\circ}$ de amplitude em longitude e em faixas $4^{\circ}$ de amplitude em latitude (figura 17). A partir dessa articulação, é feita a subdivisão em escalas maiores, tendo-se desta forma, um conjunto de mapas que variam da escala de 1:1.000.000 até 1:25.000.

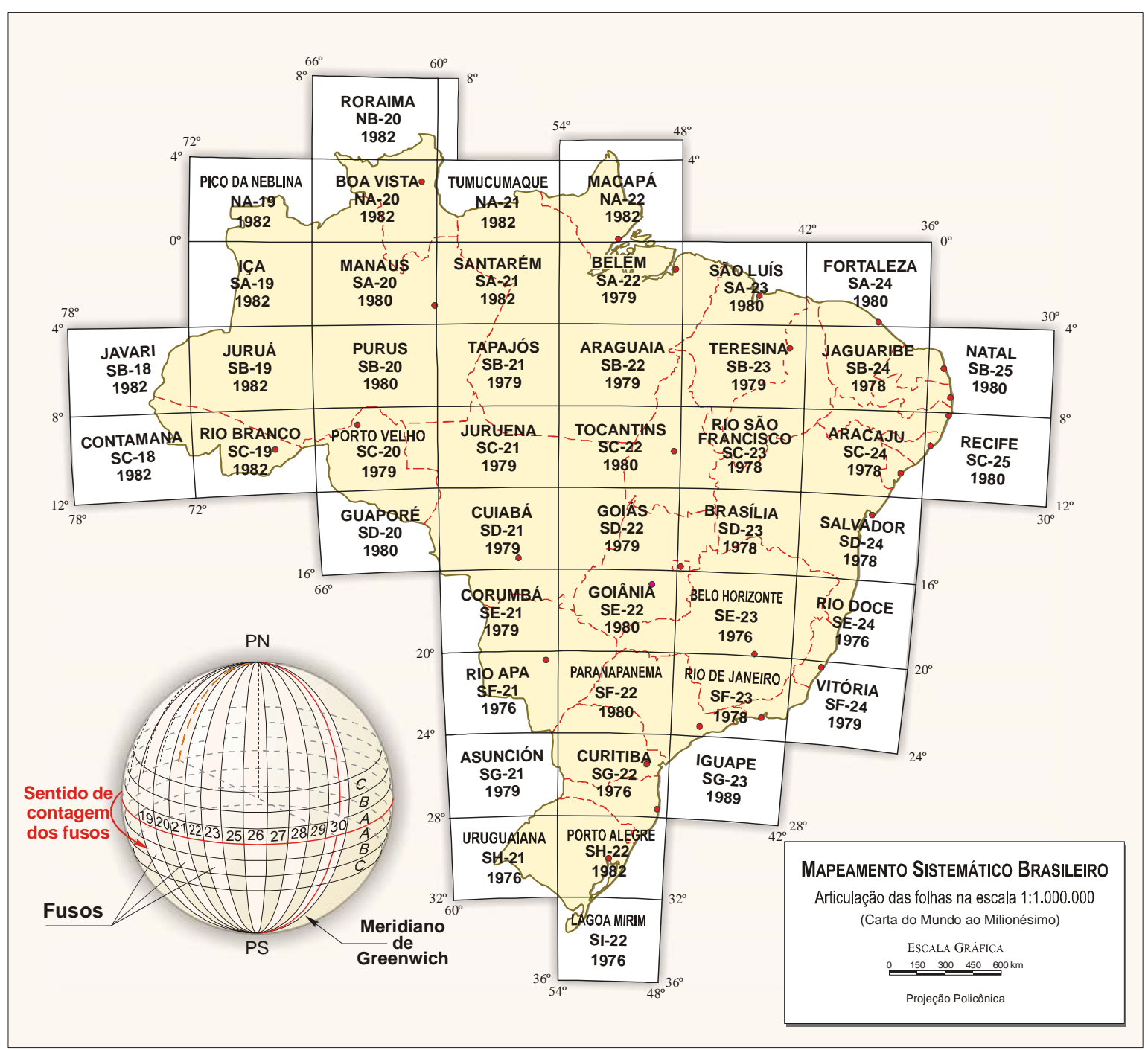

Figura 17 - Carta Internacional do Mundo ao Milionésimo. Articulação das folhas sobre o Brasil. 
A tabela 3 mostra o número de folhas do mapeamento sistemático existentes em função da escala. Esta tabela foi adaptada incluindo-se a área de abrangência das folhas em relação à amplitude em latitude e longitude. Observa-se que grande parte do território nacional é coberto por cartas na escala 1:100.000 e menores.

Tabela 3 - Situação do mapeamento do território brasileiro (2003)

\begin{tabular}{c|c|c|c}
\hline Escalas & $\begin{array}{c}\text { Área Coberta } \\
\text { (Latitude } \times \text { longitude) }\end{array}$ & Total de Folhas & \% Mapeamento \\
\hline $1: 1.000 .000$ & $4^{\mathrm{o}} \times 6^{\mathrm{o}}$ & 46 & 100,00 \\
\hline $1: 500.000$ & $2^{\mathrm{o}} \times 3^{\mathrm{o}}$ & 68 & 36,90 \\
\hline $1: 250.000$ & $1^{\mathrm{o}} \times 1^{\circ} 30^{\prime}$ & 444 & 80,72 \\
\hline $1: 100.000$ & $30^{\prime} \times 30^{\prime}$ & 2.289 & 75,39 \\
\hline $1: 50.000$ & $1^{\prime} \times 15^{\prime}$ & 1.647 & 13,90 \\
\hline $1: 25.000$ & $7^{\prime} 30^{\prime \prime} \times 7^{\prime} 30^{\prime}$ & 492 & 1,01 \\
\hline
\end{tabular}

fonte: http://www.moderna.com.br/geografia/projensinogeo/geobrasil/0028 (adaptado)

Por outro lado, sabe-se que $90 \%$ da cartografia nacional foi produzida entre as décadas de 60 e 80. A partir de então, o governo brasileiro não investiu recursos nessa área, provocando uma defasagem nas informações contidas nos mapas. Deve-se considerar ainda a diversidade de sistemas de referência. Além da coexistência do Datum de Córrego Alegre e o Datum SAD 69 ${ }^{4}$ e suas realizações ${ }^{5}$, adiciona-se a existência de uma

\footnotetext{
${ }^{4}$ Datum é o conjunto de parâmetros que define o sistema cartográfico de um País. Entre esses parâmetros encontra-se o modelo geométrico adotado para representar a Terra, e a posição que ele ocupa em relação à superfície física (topográfica) do País. Até meados da década de 70 o Brasil adotava o Datum de Córrego Alegre, cujo modelo é o elipsóide de Hayford. A partir de então, passou oficialmente a utilizar o SAD 69 (South American Data) cujo modelo geométrico é materializado pelo elipsóide Referência 1967. Como essa figuras tem dimensões e achatamentos diferentes, isto significa que um mesmo ponto, tem coordenadas diferentes, uma para cada Datum. Passadas três décadas, algumas pessoas continuam a utilizar em seus trabalhos o Datum antigo.

${ }^{5}$ Quando, por qualquer motivo, novos marcos são introduzidos no Sistema Geodésico do País, é necessário se proceder a um reajustamento da rede. Com esse procedimento as coordenadas de todos os marcos sofrem
} 
série de sistemas locais. Na questão do mapeamento cadastral, o problema maior reside na falta de uma padronização.

Todos este fatores mostram que o mapeamento brasileiro está parado no tempo há pelo menos 20 anos, tornando-o insatisfatório frente à demanda de cartografia para as atividades de planejamento e desenvolvimento social, econômico e ambiental.

Num projeto de arqueologia, seja ele na vertente preditiva ou de análise contextual, é primordial que se tenha uma cartografia atualizada e em escala adequada. No tocante à escala, deve-se imaginar que a base cartográfica do SIG tem que possibilitar a definição automática dos locais favoráveis a partir das variáveis locacionais de assentamento. Por exemplo, os terraços fluviais, que são um dos indicadores, para serem identificados pelo sistema, necessitam de um MNT com um nível de detalhamento só alcançado se as informações altimétricas do local também o forem. Excetuando os casos onde as empresas detentoras da concessão da obra fazem às suas expensas o levantamento da área impactada em escala apropriada, na maioria dos casos só se consegue mapeamento na escala 1:100.000. Nesta escala as curvas de nível estão com eqüidistância variando entre 40 e 50m com precisão de meia eqüidistância, ou seja, $\pm 20 \mathrm{~m}$ e $\pm 25 \mathrm{~m}$ respectivamente. Este fato, embora não inviabilize a automatização do sistema, fornece solução pouco eficiente e confiável.

Campos (2001), propõe um metodologia de identificação de terraços fluviais através da análise espectral de uma imagem LANDSAT7 -TM. Nesse trabalho foi identificado, com auxílio de fotografias aéreas (USAF 1966 - 1:60.000), terraços fluviais no curso médio do Rio Araguaia e posteriormente procurou-se estabelecer um comportamento espectral padrão. Embora esse experimento seja muito interessante, não se deve esquecer a escala cartográfica deste trabalho. Uma imagem da série LANDSAT vai

uma ligeira modificação o que seria equivalente a uma "mudança de Datum” e que recebe o nome de realização. 
permitir uma escala de trabalho não maior que 1:50.000, o que é inadequado para as necessidades da Arqueologia.

Para resolver o impasse poder-se-ia pensar no uso das imagens de satélite de alta resolução, como por exemplo, as do Eros, Ikonos ou Quickbird, cujas resoluções geométricas estão na casa de 1,8m, 1,00m e 0,61m, respectivamente. No entanto, além do custo inviável para a maioria dos setores, a sua manipulação e tratamento para esta finalidade ainda exigem mais pesquisas.

Terraços fluviais, vertentes, patamares de vertentes, cabeceiras de drenagem, topos de interflúvios e escarpas, podem ser identificadas automaticamente se for possível a geração de um MNT confiável. Tradicionalmente, a forma mais comum de geração de MNT é através de mapas de curvas de nível. A superabundância de dados nas isolinhas ${ }^{6}$ em contra posição à ausência fora delas pode provocar uma amostragem não homogênea, o que com certeza provocará erros, de modo que o MNT gerado não corresponda à realidade. Isso demonstra que a conversão não é uma coisa simples e totalmente resolvida. Em Seixas (2000), é feita uma discussão sobre essa problemática.

Outros fatores que podem indicar locais favoráveis, como corredeiras, cascalheiras pavimentos detríticos, dificilmente são localizados sem a intervenção direta do pesquisador, interpretando pares fotogramétricos ou mesmo imagens de alta definição.

No caso de locais propícios à agricultura, a obtenção de mapas de solos com escala e detalhamento adequado, é quase uma utopia. O que não dizer dos locais favoráveis a jazidas de argila (barreiros). Um geólogo experiente observando em uma fotografia a rede de drenagem e associando à formação geológica e à vegetação, rapidamente marca os locais mais propícios. Um processo automático dentro de um SIG

\footnotetext{
${ }^{6}$ Isolinha é uma representação gráfica onde uma linha representa pontos de mesmo valor. Numa carta topográfica é usual utilizar isolinhas para representar pontos de mesma altitude. Neste caso a isolinha recebe o nome de curvas de nível.
} 
envolveria um modelo probabilístico não trivial e que não teria a mesma eficácia do modo tradicional.

Toda essa problemática na geração da base cartográfica de um SIG interfere mais ou menos na eficiência do sistema, dependendo qual a escala de trabalho que se pretende atingir. Em casos de estudos arqueológicos regionais, onde a escala é pequena (1:100.000 ou menor) o fator precisão não é tão importante quanto a atualidade da informação e, neste caso, o uso de imagens de satélite vem suprindo essa necessidade.

\section{3 - A aplicabilidade do modelo preditivo}

A crescente demanda pela Arqueologia de salvamento tem ampliado o interesse pelo SIG no modo preditivo. Alguns trabalhos têm sido escritos e até algumas experiências neste sentido aconteceram. É o caso, por exemplo, dos projetos de salvamento arqueológico realizados pela Universidade Federal de Goiás que desde 1995, tem procurado avançar nessa direção. O problema da não implantação definitiva dessa tecnologia tem esbarrado na falta de uma base cartográfica confiável.

Em 2002 foi defendida uma tese de doutorado onde efetivamente concebese e implanta-se um SIG preditivo numa área piloto do Rio Paraná. Nesse trabalho realizado por Thomaz (2002), inicialmente é feita a análise dos parâmetros locacionais relevantes à cultura dos povos que habitavam a bacia do Paraná superior. A autora aborda aspectos relativos às variações climáticas, à geologia e geomorfologia regionais, à hidrografia e à vegetação, com o intuito de estabelecer uma linha de correlação entre a paisagem do passado e a atual. Em seguida, é feito um levantamento dos sítios e ocorrências já identificados na região, procurando estabelecer características geoambientais comuns.

A partir desse estudo, a autora partiu para a construção do modelo de regressão logística que, segundo Warren (1990) apud Thomaz (2002), são procedimentos estatísticos baseados em modelos probabilísticos. Esse modelo de regressão permitiu 
classificar a área de estudo, uma faixa de $40 \mathrm{~km}$ ao longo do Rio Paraná, segundo sua sensibilidade arqueológica, em alto, médio e baixo potencial (figura 18).

Uma leitura atenta desse trabalho demonstra que para se chegar ao mapa final muita teoria teve que ser posta em prática. A geração do mapa de potencial não foi algo simples e envolveu um conhecimento diversificado e relativamente profundo das ditas geociências (geologia, geomorfologia, climatologia), da arqueologia, da estatística, dos modelos probabilísticos, além é claro, de SIG. O mapa final, ao contrário do que alguns poderiam esperar, não mostrou os locais de potencial elevado, como pontos, mas sim como regiões bastante abrangentes. Uma outra característica importante foi o nível de detalhamento cartográfico trabalhado pela pesquisadora. Embora os mapas pedológicos, geológicos e geomorfologicos estivessem na escala 1:200.000, a cartografia básica que efetivamente serviu para aplicar o modelo de regressão logística estava na escala 1:10.000, o que é raro na maior parte do País.

Estes fatores em nenhum momento desmerecem este trabalho de cunho inédito no país. Servem apenas para alertar que a tecnologia de SIG envolve uma gama de conhecimentos e de detalhes na sua concepção que num primeiro momento podem vir a frustar iniciativas isoladas. Não se deve esquecer que a pesquisa arqueológica é uma atividade multidisciplinar que envolve profissionais com diferentes formações e que a tecnologia de SIG não funciona como um oráculo. É uma ferramenta extremamente poderosa e a sua eficiência é determinada pelo modo como os diversos módulos integradores se coadunam. A extrapolação desse experimento para outras áreas envolverá um novo estudo, pois o modelo só se aplica a locais de contextualização arqueológica similar ao estudado. 


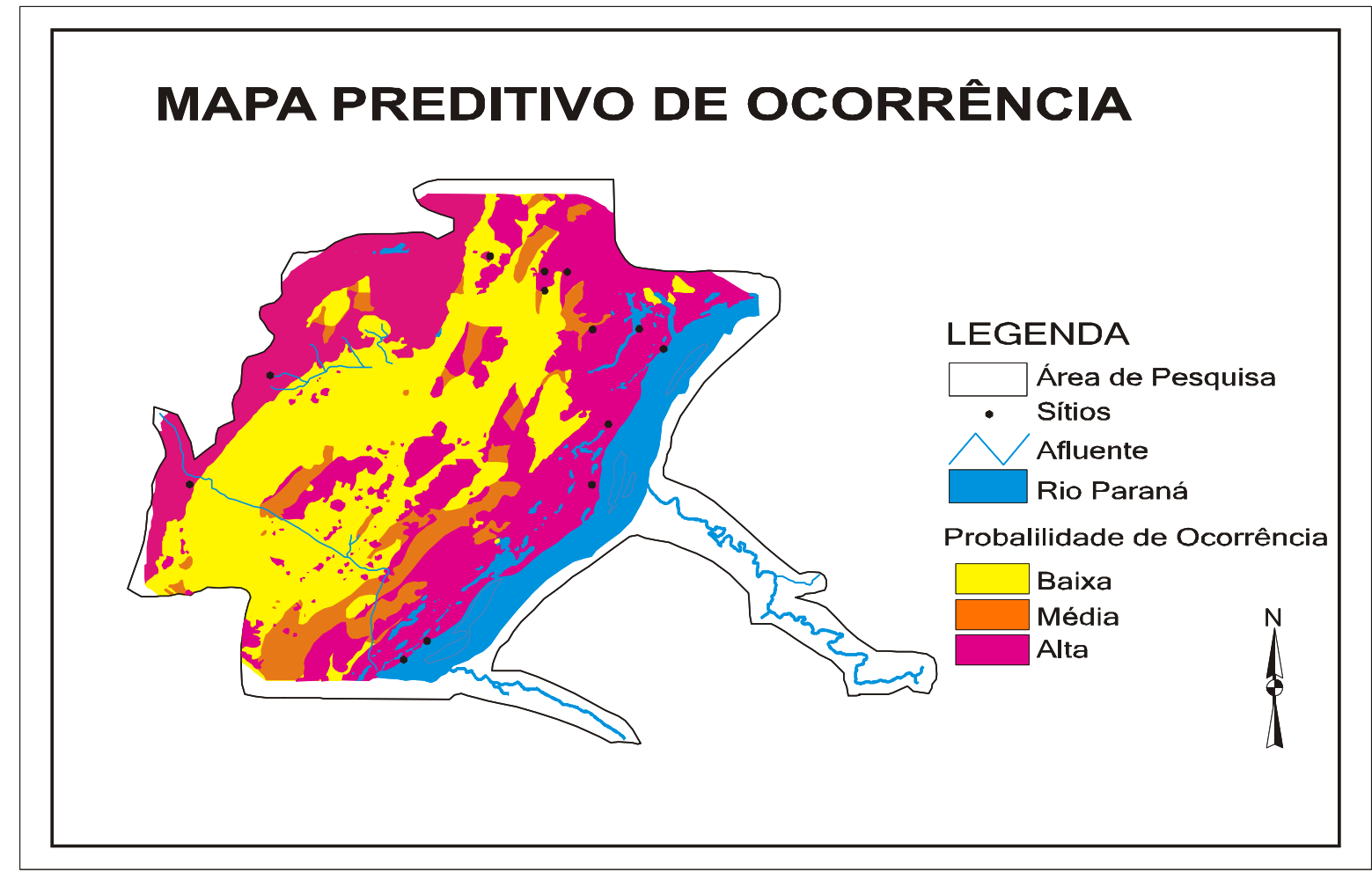

Figura 18 - Mapa de classes de probabilidade de ocorrências arqueológicas. (THOMAZ, 2002). 


\section{Capítulo III - O uso da tecnologia de SIG no contexto da inclusão social.}

\section{1 - A questão da preservação do patrimônio arqueológico}

Um dos problemas que se tem observado com respeito à área da Arqueologia, é o fato da visão estereotipada que a maior parte da população tem sobre o profissional que atua nessa área. Normalmente imagina-se um profissional estilo "Indiana Jones”, que na verdade age como um saqueador, ou um indivíduo estranho que passa a vida gastando dinheiro público e abarrotando as reservas técnicas dos museus com uma gama de traquitanas sem valor. A população em geral, não tem noção do grau de importância que o patrimônio arqueológico tem para a história do País.

A Universidade Federal de Goiás, já no Projeto de Salvamento Arqueológico Pré-Histórico da UHE Serra da Mesa (1995-98), manifestou preocupação nesse sentido. Propôs na época, como um dos seus subprojetos, o programa de Devolução Social onde, através de exposições itinerantes, vídeos e palestras, procurou sensibilizar as populações dos municípios atingidos pelo lago da usina, do tipo de trabalho que se estava fazendo e qual a sua importância. Essa experiência foi bem sucedida e essa linha de trabalho passou a ser adotada em outros projetos, inclusive realizados por outras Instituições.

Outro fato que merece ser destacado é o volume de material arqueológico ocupando espaço nas reservas sem ser devidamente estudado. Essa prática pode sim ser encarada como desperdício de dinheiro, porque todo o investimento na pesquisa arqueológica de campo e a conseqüente coleta de material dentro de rigorosos critérios técnicos, perde o sentido. Tirando as questões referentes aos egos pessoais dos diversos pesquisadores com suas linhas metodológicas, o maior problema está no desconhecimento desse patrimônio e de como acessá-lo. Esta situação atinge, inclusive, os arqueólogos. 
Deve-se ter em mente que o acesso não se restringe apenas aos artefatos, mas sim a todas as informações, inclusive as de cunho geoambiental.

O Instituto Nacional do Patrimônio Histórico e Artístico Nacional (IPHAN) tem direcionado seus esforços no sentido de promover a difusão da informação. Como exemplo tem-se o banco de dados desenvolvido em Access denominado "Sistema de Gerenciamento do Patrimônio Arqueológico Brasileiro (SGPAB)", cuja última versão disponível na Internet é datada de 20 de abril de 1999. Este sistema tem a pretensão de, a partir do armazenamento das informações arqueológicas produzidas no País, servir como fonte de referência aos pesquisadores sobre onde e o que se está fazendo. Contudo, por problemas de ordem administrativa (operacional) e de aceitação por parte dos arqueólogos, a implantação deste cadastro não está avançando na velocidade desejável. A comunidade reclama que as informações requeridas pelo formulário do sistema são inadequadas, não atendendo necessidades localizadas. O fato é que não se têm informações atualizadas no sistema e a reversão desse quadro passa necessariamente por uma política de divulgação da pesquisa arqueológica no País. Esta é uma forma extremamente interessante e eficaz de proteção do patrimônio, uma vez que só se preserva aquilo que se conhece.

Um bom modo de disponibilizar essas informações é a utilização, por parte das próprias instituições produtoras do conhecimento arqueológico, da Internet. Contudo, pode-se atingir melhor o objetivo se estes dados estiverem estruturados com base na tecnologia de SIG. Essa ferramenta de análise permite ao pesquisador usuário interagir com os dados originais e produzir novos dados de acordo com as suas necessidades.

\section{2 - SIG enquanto instrumento de socialização do conhecimento.}

Os trabalhos de SIG têm se concentrado dentro da área de arqueologia em três vertentes. A primeira é referente ao SIG preditivo, onde se procura gerar cartas de potencial arqueológico. Esta linha é ainda incipiente no País, provavelmente pela complexidade e custo dos programas de SIG e, principalmente pela falta de uma cartografia atualizada e numa escala mais apropriada. 
A segunda tem utilizado a ferramenta no sentido de capturar, visualizar e analisar as informações arqueológicas no contexto local e/ou regional. A de contexto local é o que se poderia chamar estudo intra-sítio, e trabalhos como os de Breman (2003), Craig (2003) e Friedman (2003) são exemplos desse tipo de análise. Na mesma linha, porém tratando o problema no contexto regional, o que poderia ser entendido como arqueologia da paisagem (MoRAIS, 1999), aparecem os trabalhos de Barry III (2003), Brewster (2003), Dyson-Bruce (2003), Jennings (2003) e Kneip (2004).

Finalmente, na terceira direção aparecem trabalhos onde a tônica é a gestão do pratimônio arqueológico, ou seja, o SIG é utilizado para controlar e compartilhar as informações arqueológicas. Dureka (2003), Comer (2003), Box (2003) e Johnson (2003) são alguns exemplos dessa vertente.

Um SIG além de ser um instrumento de análise é, também, uma plataforma integradora de informações, onde dados geográficos e não geográficos estão interligados. Essa característica permite que informações que não participam diretamente da análise possam ser acessadas. É o caso, por exemplo, de fotografias de locais (sítios) ou de artefatos (cultura material), que embora não sejam utilizadas no cruzamento, permitem que o pesquisador as tenha ao seu dispor como fontes que lhe darão subsídios para a tomada de decisões. Esta potencialidade permite que se pense em conceber um sistema onde multimídia e SIG estejam integrados de forma que qualquer usuário, segundo o seu interesse pessoal, possa acessá-las da maneira que melhor lhe convier.

\section{3 - SIG aplicado à inclusão social.}

No capítulo I deste trabalho é mostrada toda a evolução do SIG através das diversas arquiteturas propostas e as tendências atuais, principalmente, no que diz respeito ao uso da Internet. Percebe-se, através do texto, que antes de se definir software/hardware deve-se discutir qual o propósito e qual o público que se pretende atingir. Deste modo, um SIG voltado à inclusão social deve primar pela simplicidade, pois é condição sine qua non atingir pessoas não afeitas às ferramentas de geoprocessamento. 
Para se mostrar a aplicabilidade do SIG como difusor de conhecimento escolheu-se o Projeto de Salvamento Arqueológico da UHE Corumbá IV (PA-SALVC/IV) como fonte de dados ao experimento. Esta escolha teve como principal motivação, o fato de que, desde o seu início, houve a preocupação em estruturar os dados visando a geração de um SIG voltado às necessidades da Arqueologia.

O PA-SALV-C/IV foi executado pela equipe do Laboratório de Arqueologia (LabArq) do Museu Antropológico (MA) da Universidade Federal de Goiás (UFG) na região leste do estado de Goiás, abrangendo os municípios goianos de Luziânia, Santo Antônio do Descoberto, Alexânia, Abadiânia e Silvânia.

Habitada desde a pré-história, a área assume uma importância ímpar por estar situada no que se costuma chamar de Entorno de Brasília, Capital da República Federativa do Brasil. Esse fato permite afirmar que existe atualmente uma diversidade populacional muito grande, oriunda dos ciclos migratórios na região.

A extensão do empreendimento é marcada por especificidades culturais singulares, que expressam os processos de ocupação, circulação, transformação e reaproveitamento humano ocorridos na região, da pré-história aos dias atuais.

Durante a realização da pesquisa verificou-se que a diversidade étnica mencionada pode ser comprovada nos municípios de Abadiânia, Alexânia, Santo Antônio do Descoberto e Silvânia, próximos ao de Luziânia. Observou-se ainda que, desde a implantação das primeiras fazendas, a vocação principal da região está centrada em atividades agrícola, marcada pela exploração da terra e complementada por atividades de pecuária. Esta situação é confirmada pelos diversos testemunhos históricos encontrados.

As pesquisas bibliográficas efetuadas sobre a área do empreendimento mostram que as populações pré-coloniais, constituídas por grupos de caçadores-coletores, não transitaram nem levantaram seus acampamentos sazonais na área investigada. Essa 
constatação permite inferir que a Bacia Hidrográfica do Rio Corumbá não forneceu às populações pretéritas de caçadores-coletores as condições adequadas para a sobrevivência.

Em primeira aproximação pode-se especular que a Bacia do Rio Corumbá é caracterizada pela presença de aldeias ou acampamentos de agricultores ceramistas que procuravam locais que estivessem associados à captação de matérias-prima (oficinas de redução primária), captura de peixes e demais recursos ambientais.

Em Martins (2004) é feita a seguinte descrição:

A área de Influência da UHE Corumbá IV foi ocupada, preferencialmente, por populações pretéritas que dominavam a técnica de confecção de objetos cerâmicos. Constituíam núcleos residenciais que devem ter sido interrompidos pela conquista européia e pela formação da sociedade brasileira, incluindo as situações de contato.

Os assentamentos típicos de agricultores ceramistas caracterizam-se como a mais concreta representação material da complexidade social desses grupos humanos. Essas populações escolheram compartimentos topomorfológicos caracterizados por terraço, planície de sedimentação, interflúvio, superfície de aplainamento e encosta de média declividade. Nas suas adjacências ocorrem afloramentos rochosos, pavimentos detríticos, lençóis de cascalheiras e barreiros, possíveis áreas fontes de matérias-primas apropriadas para a fabricação de artefatos - lítico e vasilhame cerâmico.

Os sítios pré-coloniais, de natureza lito-cerâmica, caracterizam-se pela presença de testemunhos líticos e cerâmicos. São populações mais recentes que as de caçadorescoletores, mas que antecedem os grupos responsáveis pelas frentes de expansão na região.

As populações humanas que se instalaram nessa região selecionaram diferentes locais, a céu-aberto, para se fixarem. As pesquisas arqueológicas comprovam que os grupos humanos pré-coloniais ceramistas escolheram ambientes topomorfológicos distintos para construir vastas aldeias. As aldeias, formadas por cabanas de diferentes tamanhos e dispostas de formas variadas, vêm sendo identificadas em locais situados nas proximidades de rios, córregos e/ou ribeirões. Esses locais se caracterizam pela presença de testemunhos cerâmicos - lisos e/ou decorados; de vasilhas grandes e pequenas, utilizadas das mais 
variadas formas pelos seus produtores; de peças fabricadas em pedra lascada e em pedra polida, e de tantos outros objetos necessários à sobrevivência dessas populações.

Foi constatado que a maioria dos sítios, registrados na área, estavam destruídos ou mal conservados, o que sem dúvida limita a compreensão do contexto de inserção dos registros arqueológicos e, conseqüentemente, os processos culturais ocorridos ao longo do tempo.

Com respeito à Arqueologia histórica, a leitura do relatório final do PASALV-C/IV, mostra que houve a implantação de vários arraiais correspondentes ao período histórico ocorrido na região nos séculos XVIII e XIX , conhecido como a febre do ouro. A pesquisa bibliográfica esclareceu que foram expedições paulistas que ocuparam a região vislumbrando a escravização indígena e a descoberta de minas de ouro.

A presença de sedes-fazendeiras é documentada desde o século XIX, embora pouco registrada pelos historiadores . A utilização de mão-de-obra negra (escrava) levada para a região associada à indígena (capturada nas cercanias), nas atividades rotineiras nas sedes de fazenda, foi relatada.

A barragem está localizada no rio Corumbá a $4 \mathrm{~km}$ a jusante da foz do córrego Descoberto, nas coordenadas 16 $19^{\circ}$ '22” de latitude sul e 48¹1'15” de longitude oeste e o seu reservatório ocupará uma área correspondente a $187,7 \mathrm{~km}^{2}$. O nível da água apresentará uma oscilação entre as altitudes 842m a 856m (figura 19). 


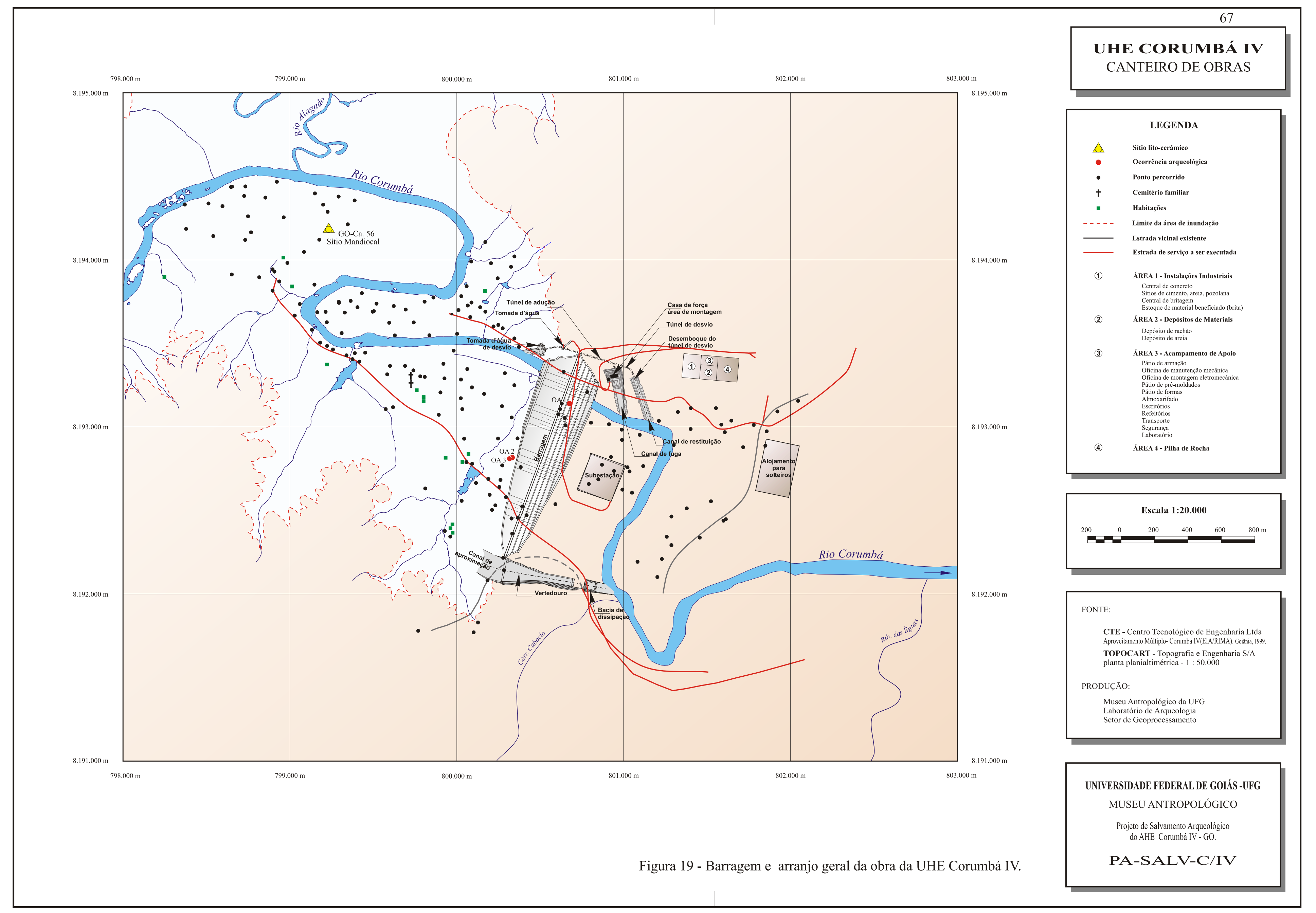


Esse projeto, iniciado em abril de 2002, teve duração de 24 meses. Foram encontrados na área 40 sítios arqueológicos, sendo 11 do tipo histórico, 29 de natureza litocerâmica, e ainda 30 ocorrências arqueológicas. Durante a fase de levantamento foram vistoriados, além dos já mencionados, 70 pontos de interesse arqueológico, 2.416 locais devidamente georreferenciados com auxílio de um GPS de navegação (pontos percorridos). (figuras 20, 21 e 22)

Nas Tabela 4 e 5 estão listados os sítios e as ocorrências arqueológicas com suas respectivas coordenadas UTM (Universal Transversa de Mercator) e os municípios.

Tabela 4 - Sítios arqueológicos registrados na área de influência da UHE Corumbá IV

\begin{tabular}{|c|c|c|c|c|c|}
\hline \multirow{2}{*}{$\mathbf{N}^{\mathbf{o}}$} & \multirow{2}{*}{ SIGLA } & \multirow{2}{*}{ NOME } & \multicolumn{2}{|c|}{ COORDENADAS UTM } & \multirow{2}{*}{ MUNICÍPIO } \\
\hline & & & $E(\mathbf{m})$ & $\mathbf{N}(\mathbf{m})$ & \\
\hline 1 & GO-Ca.56 & Mandiocal & 799.232 & 8.194 .158 & Luziânia \\
\hline 2 & GO-Ca.57 & Caracará & 799.445 & 8.195.156 & Luziânia \\
\hline 3 & GO-Ca.58 & Coruja & 795.280 & 8.190 .858 & Luziânia \\
\hline 4 & GO-Ca.59 & Faz. Paulista 1 & 803.805 & 8.206.291 & Luziânia \\
\hline 5 & GO-Ca.60 & Faz. Paulista 2 & 805.505 & 8.209.272 & Luziânia \\
\hline 6 & GO-Ca.61 & Faz. Lagoinha & 790.401 & 8.206 .732 & Sto. Antônio do Descoberto \\
\hline 7 & GO-Ca.62 & Andorinha & 787.717 & 8.205.789 & Sto. Antônio do Descoberto \\
\hline 8 & GO-Ca.63 & Canário & 788.827 & 8.206.809 & Sto. Antônio do Descoberto \\
\hline 9 & GO-Ca.64 & Três Potes & 788.749 & 8.206 .962 & Sto. Antônio do Descoberto \\
\hline 10 & GO-Ca.65 & Curió & 788.938 & 8.207.176 & Sto. Antônio do Descoberto \\
\hline 11 & GO-Ca.66 & Pássaro Preto & 789.882 & 8.217.015 & Sto. Antônio do Descoberto \\
\hline 12 & GO-Ca.67 & Sabiá & 792.309 & 8.194.348 & Sto. Antônio do Descoberto \\
\hline 13 & GO-Ca.68 & Faz. São Bernardo & 784.909 & 8.195.914 & Alexânia \\
\hline 14 & GO-Ca.69 & Rolinha & 782.209 & 8.195.946 & Alexânia \\
\hline 15 & GO-Ca.70 & Ema & 788.311 & 8.191 .554 & Luziânia \\
\hline
\end{tabular}


Tabela 4 - Sítios arqueológicos registrados na área de influência da UHE Corumbá IV (continuação)

\begin{tabular}{|c|c|c|c|c|c|}
\hline \multirow{2}{*}{$\mathbf{N}^{\mathbf{0}}$} & \multirow{2}{*}{ SIGLA } & \multirow{2}{*}{ NOME } & \multicolumn{2}{|c|}{ COORDENADAS UIM } & \multirow{2}{*}{ Município } \\
\hline & & & $E(m)$ & $\mathbf{N}(\mathbf{m})$ & \\
\hline 16 & GO-Ca.71 & Juriti & 788.570 & 8.189.078 & Luziânia \\
\hline 17 & GO-Ca.72 & Perdiz & 787.856 & 8.188 .426 & Luziânia \\
\hline 18 & GO-Ca.73 & Jaó & 788.306 & 8.193.764 & Luziânia \\
\hline 19 & GO-Ca.74 & Pica-pau & 785.840 & 8.190 .372 & Luziânia \\
\hline 20 & GO-Ca.75 & Tucano & 787.742 & 8.198.380 & Luziânia \\
\hline 21 & GO-Ca.76 & Faz. Corumbá & 783.586 & 8.192 .160 & Luziânia \\
\hline 22 & GO-Ca.77 & Colibri & 781.680 & 8.192 .424 & Luziânia \\
\hline 23 & GO-Ca.78 & Faz. Buriti Madeira & 775.701 & 8.193.348 & Silvânia \\
\hline 24 & GO-Ca.79 & Garça Branca & 776.653 & 8.197.084 & Silvânia \\
\hline 25 & GO-Ca.80 & Codorna & 775.772 & 8.197.171 & Silvânia \\
\hline 26 & GO-Ca.81 & Fazenda Cervo & 778.390 & 8.193 .870 & Silvânia \\
\hline 27 & GO-Ca.82 & Chodó & 772.608 & 8.193.926 & Silvânia \\
\hline 28 & GO-Ca.83 & Gavião & 771.721 & 8.192.956 & Silvânia \\
\hline 29 & GO-Ca.84 & Faz. Engenho Velho & 772.292 & 8.194.244 & Silvânia \\
\hline 30 & GO-Ca.85 & Papagaio & 772.052 & 8.193 .947 & Silvânia \\
\hline 31 & GO-Ca.86 & Siriri & 770.744 & 8.199.541 & Abadiânia \\
\hline 32 & GO-Ca.87 & Coleirinho & 770.231 & 8.200 .180 & Abadiânia \\
\hline 33 & GO-Ca.88 & João de Barro & 770.670 & 8.196.979 & Abadiânia \\
\hline 34 & GO-Ca.89 & Quero-Quero & 774.389 & 8.202.978 & Abadiânia \\
\hline 35 & GO-Ca.90 & Seriema & 766.178 & 8.206 .127 & Abadiânia \\
\hline 36 & GO-Ca.91 & Acauã & 766.573 & 8.196.301 & Alexânia \\
\hline 37 & GO-Ca.92 & Tiziu & 777.483 & 8.198 .402 & Alexânia \\
\hline 38 & GO-Ca.93 & Curicaca & 777.258 & 8.198.989 & Alexânia \\
\hline 39 & GO-Ca.94 & Gralha & 768.247 & 8.207 .806 & Alexânia \\
\hline 40 & GO-Ca.95 & Pipira & 759.991 & 8.211 .450 & Alexânia \\
\hline
\end{tabular}

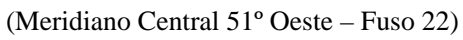


Tabela 5 - Ocorrências arqueológicas registradas na área de influência da UHE Corumbá IV.

\begin{tabular}{|c|c|c|c|c|}
\hline \multirow{2}{*}{$\mathbf{N}^{\mathbf{0}}$} & \multirow{2}{*}{ SIGLA } & \multicolumn{2}{|c|}{ COORDENADAS UTM } & \multirow{2}{*}{ Município } \\
\hline & & $\mathbf{E}(\mathbf{m})$ & $\mathbf{N}(\mathbf{m})$ & \\
\hline 1 & OA 1 & 800.675 & 8.193 .140 & Luziânia \\
\hline 2 & OA 2 & 800.316 & 8.192 .810 & Luziânia \\
\hline 3 & OA 3 & 800.332 & 8.192.817 & Luziânia \\
\hline 4 & OA 4 & 803.022 & 8.206 .085 & Luziânia \\
\hline 5 & OA 5 & 801.927 & 8.203 .018 & Luziânia \\
\hline 6 & OA 6 & 796.598 & 8.193 .128 & Luziânia \\
\hline 7 & OA 7 & 794.558 & 8.188 .671 & Luziânia \\
\hline 8 & OA 8 & 794.594 & 8.188 .409 & Luziânia \\
\hline 9 & OA 9 & 787.470 & 8.206 .093 & Sto. Antônio do Descoberto \\
\hline 10 & OA 10 & 787.613 & 8.205 .809 & Sto. Antônio do Descoberto \\
\hline 11 & OA 11 & 789.778 & 8.214 .696 & Sto. Antônio do Descoberto \\
\hline 12 & OA 12 & 783.495 & 8.214.348 & Sto. Antônio do Descoberto \\
\hline 13 & OA 13 & 786.011 & 8.194.188 & Alexânia \\
\hline 14 & OA 14 & 785.819 & 8.194 .761 & Alexânia \\
\hline 15 & OA 15 & 785.276 & 8.196 .172 & Alexânia \\
\hline 16 & OA 16 & 786.454 & 8.191.918 & Luziânia \\
\hline 17 & OA 17 & 784.648 & 8.190 .712 & Luziânia \\
\hline 18 & OA 18 & 784.862 & 8.190 .511 & Luziânia \\
\hline 19 & OA 19 & 778.141 & 8.193 .693 & Silvânia \\
\hline 20 & OA 20 & 777.649 & 8.194 .305 & Silvânia \\
\hline 21 & OA 21 & 786.453 & 8.190 .597 & Luziânia \\
\hline 22 & OA 22 & 772.240 & 8.195 .146 & Silvânia \\
\hline 23 & OA 23 & 772.548 & 8.195 .658 & Silvânia \\
\hline 24 & OA 24 & 772.757 & 8.196 .837 & Silvânia \\
\hline 25 & OA 25 & 771.373 & 8.199.385 & Abadiânia \\
\hline 26 & OA 26 & 768.715 & 8.196.933 & Abadiânia \\
\hline 27 & OA 27 & 773.660 & 8.198.137 & Abadiânia \\
\hline 28 & OA 28 & 774.253 & 8.201 .169 & Abadiânia \\
\hline 29 & OA 29 & 773.376 & 8.205 .960 & Abadiânia \\
\hline 30 & OA 30 & 767.259 & 8.209.731 & Alexânia \\
\hline
\end{tabular}

(Meridiano Central $51^{\circ}$ Oeste - Fuso 22) 


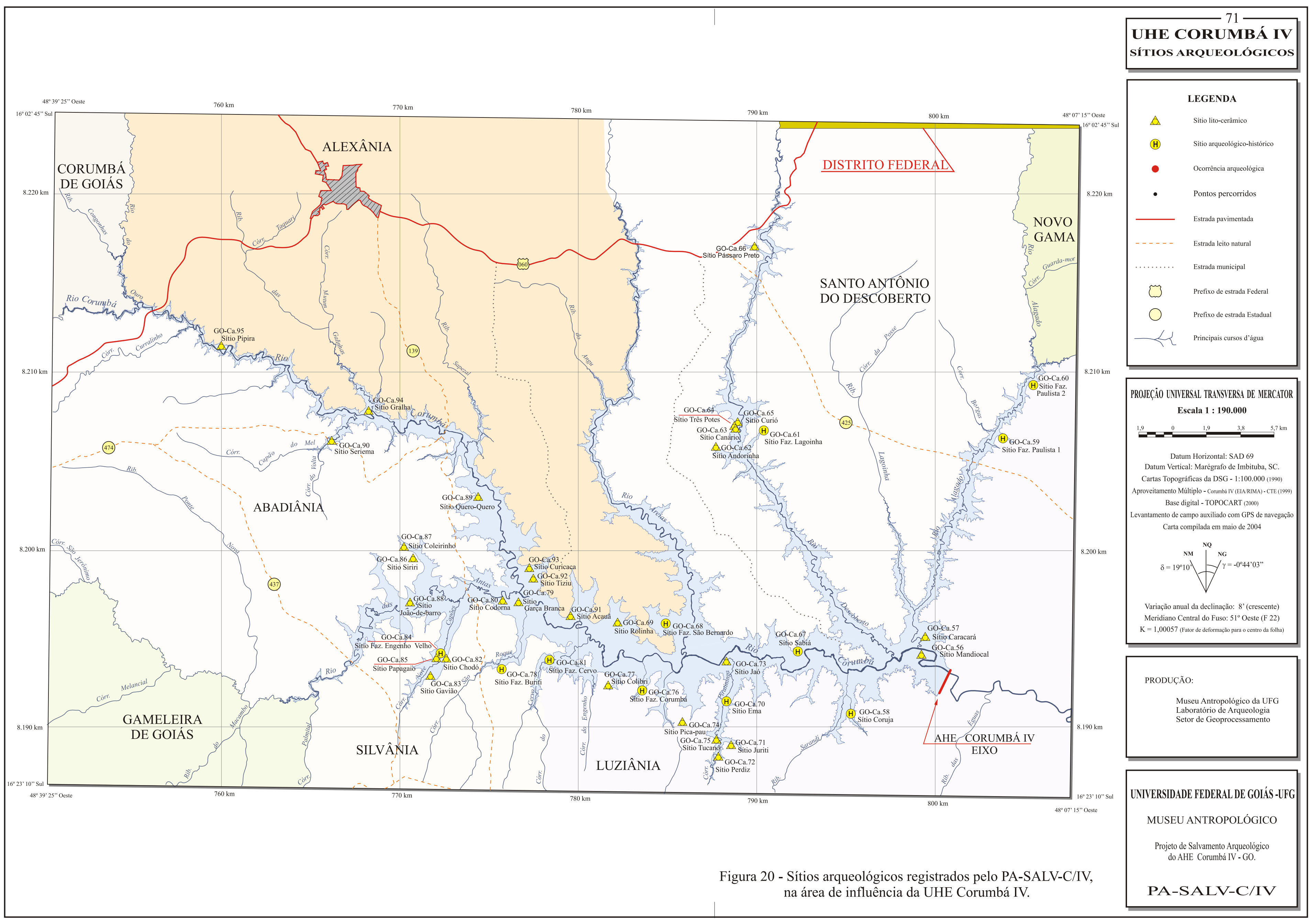




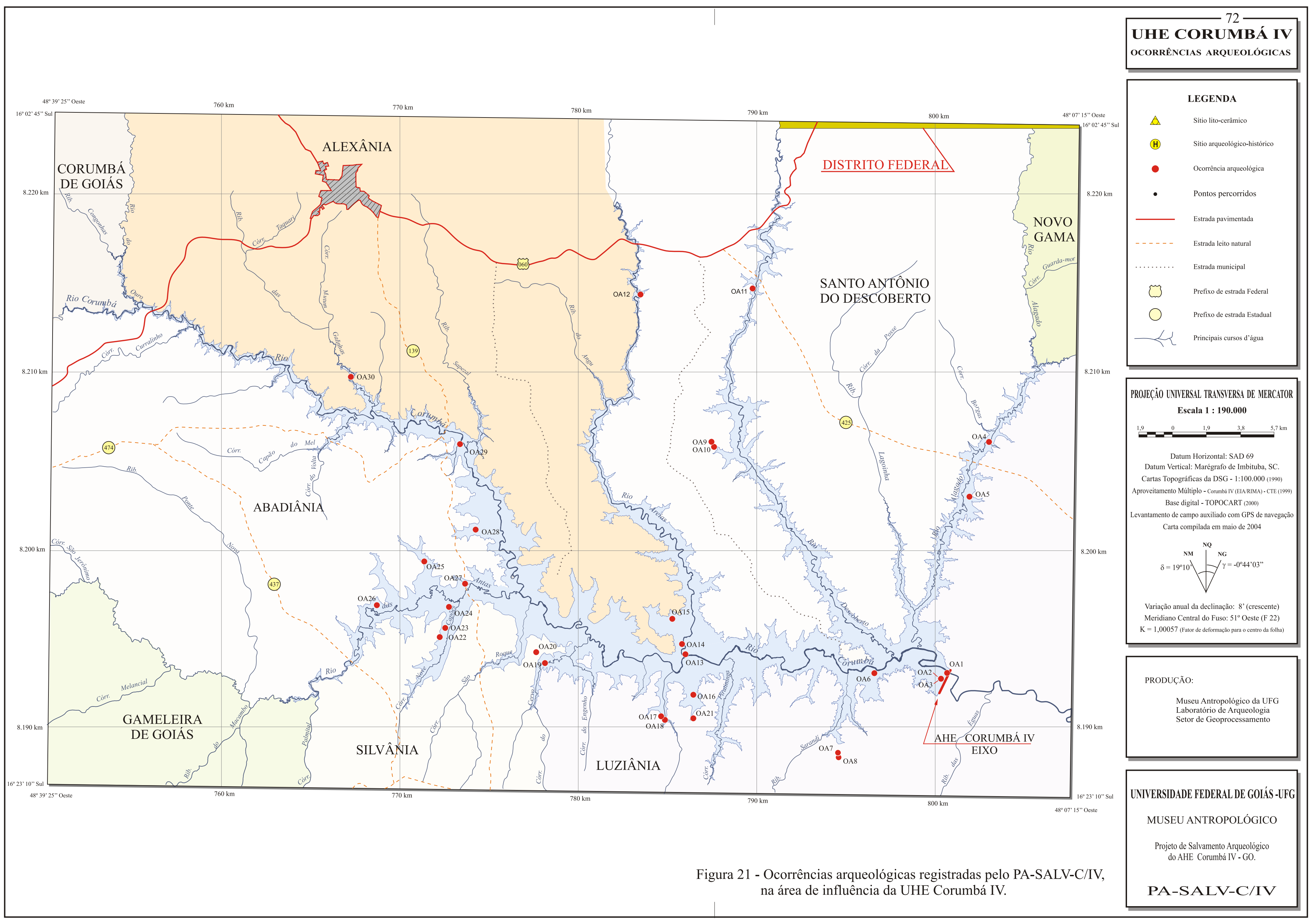




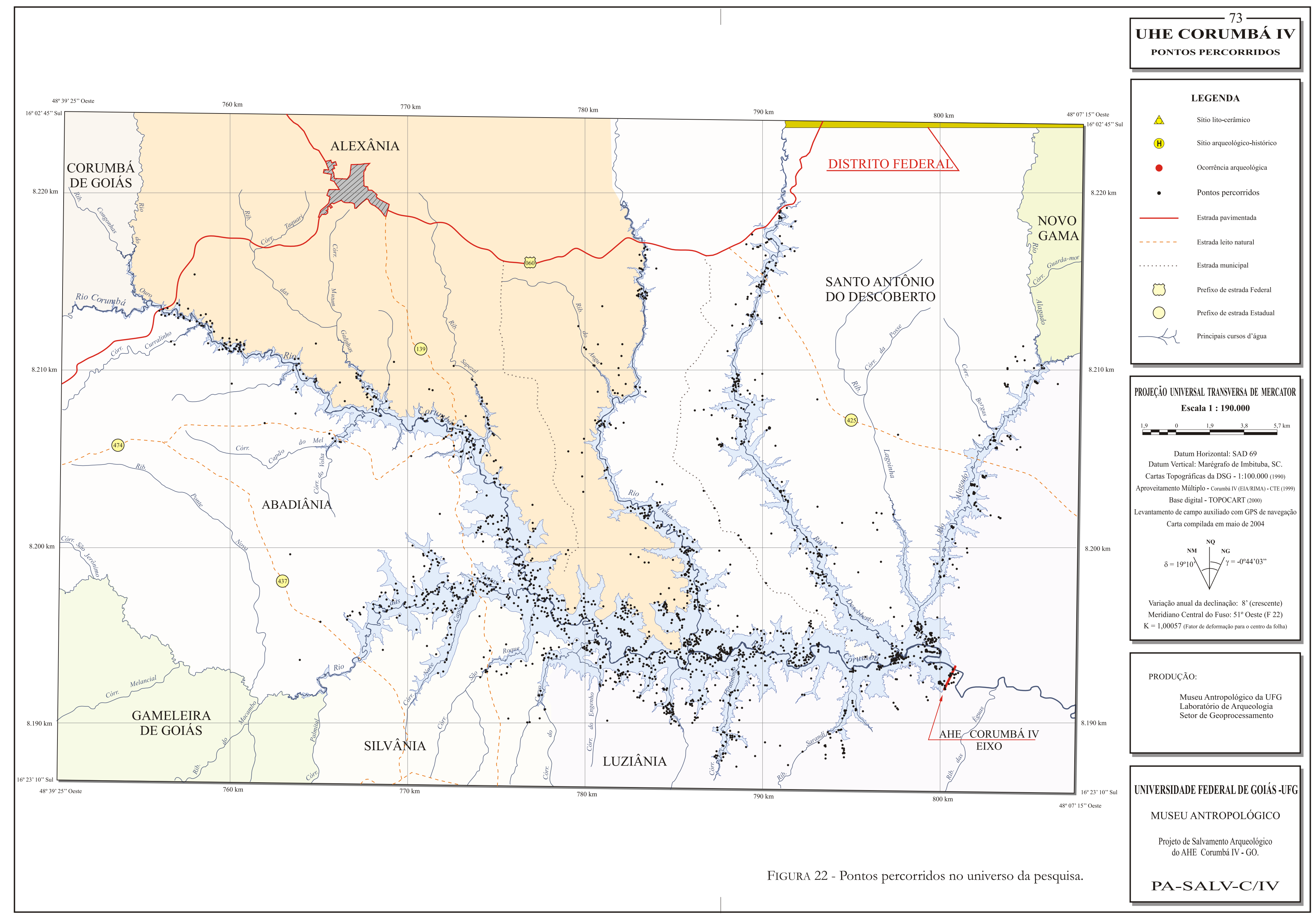


O relatório final deste projeto intitulado "UHE Corumbá IV: da arqueologia pré-colonial aos dias atuais” é composto por 4 volumes principais, a saber:

Volume I - PA-SALV-C/IV: das narrativas sobre as parcerias envolvidas no programa arqueológico;

Volume II - PA-SALV-C/IV: do registro ao cadastramento dos sítios arqueológicos.

Volume III - PA-SALV-C/IV: a arqueologia da UHE Corumbá IV por meio de uma síntese arqueológica

Volume IV - PA-SALV-C/IV: dos resultados à elaboração de produtos de inclusão social visando a arqueologia pública.

No volume I, considerado pela autora como de caráter genérico, é feita uma releitura do projeto inicial introduzindo-se dados quantitativos e sistematizados. Avaliamse as responsabilidades dos parceiros envolvidos (Funape; MA/LabArq; Corumbá Concessões S.A.) durante o desenvolvimento do projeto e apontam-se as perspectivas de continuidade dos estudos acadêmicos nas metas traçadas para serem alcançadas dentro do médio e longo prazo. Reforça-se a necessidade de se estabelecer um processo contínuo de monitoramento das paisagens arqueológicas submersas como parte de uma política de preservação do patrimônio cultural.

O volume II é composto pelas fichas de registro de sítios arqueológicos padronizadas pelo Ministério da Cultura/Sistema Nacional de Informações Culturais (SNIC) por intermédio do Instituto do Patrimônio Histórico e Artístico Nacional (IPHAN)/Departamento de Identificação e Documentação (DID). Esse volume atende às exigências legais destinadas ao cadastramento do patrimônio arqueológico brasileiro e proporciona, nacionalmente, a divulgação oficial das informações gerais que caracterizam os sítios arqueológicos pesquisados no universo do projeto.

No volume III é feita a síntese arqueológica a partir dos dados coletados pela pesquisa e pelos estudos anteriormente executados na área. Segundo Martins et al 
(2004), “... esse volume se estrutura e se consolida a partir de uma gama diversificada de informações qualitativas, referentes às populações que deixaram testemunhos da sua presença na área, da pré-história aos dias atuais.”

No volume IV são apresentados alguns produtos destinados ao público em geral e tem o propósito de sensibilizar a sociedade sobre a importância do patrimônio arqueológico e de sua preservação. São produtos direcionados aos professores e alunos do ensino fundamental e médio das redes pública e privada. Esse público, no entender dos autores, são excelentes agentes multiplicadores e modificadores da visão distorcida e equivocada que grande parte do povo brasileiro tem sobre o patrimônio cultural, a arqueologia e o exercício dessa profissão.

Os produtos propostos no volume IV procuram demonstrar o potencial da fotografia, do desenho, das amostras de plantas desidratadas, das imagens captadas em filme e da cartografia no esclarecimento de aspectos nem sempre perceptíveis, mas importantes no contexto arqueológico e cultural da região. Das pesquisas realizadas, gerouse também uma publicação impressa contendo fragmentos conceituais da Arqueologia de Corumbá IV. Em resumo são sugeridos os seguintes materiais para servirem como divulgadores do Projeto:

- Luz e memória: atrás de uma câmera a preservação patrimonial de um espaço goiano.

- A tradução de expressões sensíveis da vida social em uma versão afigurada.

- Plantas medicinais utilizadas popularmente no Vale do Rio Corumbá.

- PA-SALV-C/IV: da Arqueologia pré-colonial aos dias atuais.

- UHE Corumbá IV: cartografia de sítios arqueológicos.

- Usina Hidrelétrica Corumbá IV: da pré-história aos dias atuais. 
Além desse material em mídia digital e impresso, o setor de geoprocessamento do LabArq/MA/UFG sistematizou os dados cartográficos e não cartográficos no sentido de produzir um SIG voltado às necessidades do projeto.

A construção do SIG Corumbá IV passou por algumas etapas iniciais. Definiu-se primeiramente qual a base cartográfica que seria adotada. Como esperado, as cartas oficiais para a região estão na escala 1:100.000. A empresa construtora (Corumbá Concessões S.A.) possuía material em escala melhor, porém restrita a área inundável. Normalmente, nos projetos de salvamento, a pesquisa é efetuada na área de influência direta e indireta. A primeira área estava coberta pelo mapa em escala melhor, no entanto a outra não. Resolveu-se, apesar do problema, adotar as cartas oficiais produzidas pela Diretoria do Serviço Geográfico do Exército (DSG), cujos dados estão na tabela 6.

Tabela 6 - Cartas topográficas utilizadas no PA-SALV-C/IV.

\begin{tabular}{l|l|c|c|c}
\hline \multicolumn{1}{c|}{ Nome } & Nomenclatura & Escala & $\begin{array}{c}\text { Eqüidistância } \\
\text { das Curvas } \\
\text { de Nível }\end{array}$ & Publicação \\
\hline \hline Anápolis & SE22-X-B-II & \multirow{2}{*}{$1: 100.000$} & $40 \mathrm{~m}$ & 1981 (2. ed) \\
\cline { 1 - 2 } Gama & SE22-X-B-III & & & 1980 (2. ed) \\
\hline
\end{tabular}

Definida a base cartográfica, criou-se um retângulo envolvente, limitado pelas latitudes $16^{\circ} 02^{\prime} 45^{\prime}$ 'sul e $16^{\circ} 23^{\prime} 10^{\prime}$ ”sul e longitudes $48^{\circ} 07^{\prime} 15^{\prime}$ ”oeste e $48^{\circ} 39^{\prime} 25^{\prime}$ ”oeste.

Com a utilização de uma mesa digitalizadora Digigraf, modelo Van Gogh padrão A1, foi processada a digitalização das cartas topográficas convertendo os dados do modo analógico (papel) para o modo digital. Foram extraídas a rede hidrográfica e viária, as curvas de nível e os limites dos municípios. 
Todas essas informações foram editadas no ambiente do AutoCad Map (Autodesk) $^{7}$ com o intuito de criar a topologia para o SIG Corumbá IV.

Com respeito aos Sítios, ocorrências e pontos percorridos, a cada retorno da equipe do Labarq/MA da área do empreendimento, a caderneta de campo era consultada e os dados transcritos para a planilha Excell. Essa providência foi importante porque a transposição da planilha para o programa ArcGIS (ESRI) ${ }^{8}$ é mais tranqüila. A cada análise laboratorial que pudesse gerar uma informação importante, essa era anexada na planilha.

Por fim a base de dados ficou com os seguintes campos de informação: sigla, nome, coordenadas UTM (E,N, Fuso), coordenadas geográficas (latitude e longitude), altitude, local, proprietário, município, tipologia, proximidade cultural, dimensões (comprimento, largura, área), integridade e tipo de solo.

\section{4 - Estruturação dos dados visando o SIG aplicado à inclusão social.}

A estruturação do SIG, na visão da inclusão social, seguiu a filosofia de fornecer ao usuário a possibilidade de interagir com as informações num ambiente computacional independentemente do seu conhecimento prévio da tecnologia de SIG. Deste modo, a concepção foi baseada no uso de um sistema multimídia onde o SIG é parte integrante, mas não principal.

\footnotetext{
${ }^{7}$ A Autodesk, Inc., empresa mundial de soluções de desenho, auxilia mais de 5.000 .000 de profissionais da indústria, em mais de 160 países, na modelagem, criação, administração e comercialização de seus projetos - de hotéis, viadutos, edifícios, elevadores, gerência de redes para empresas de serviço público, e até efeitos especiais premiados com o Oscar. Oferece uma grande variedade de soluções totalmente integradas, que incluem tecnologias Web, mobile e wireless, em softwares para projetos de arquitetura e construção, engenharia, sistemas de informação geográfica e manufatura. Fundada em 1982, a Autodesk é uma das maiores companhias de software global.

${ }^{8}$ A ESRI, Environmental Systems Research Institute, fundada em 1969, é uma empresa dedicada exclusivamente à implementação e ao uso de mapas digitais e sistemas computadorizados de informações geográficas. Contando atualmente com mais de 1.400 funcionários em sua sede em Redlands, Califórnia, e em escritórios regionais e internacionais, a ESRI tem conduzido uma grande variedade de projetos vinculados à tecnologia SIG/GIS, nos EUA e no restante do mundo, para clientes de diferentes segmentos do mercado privado e também para o setor público.
} 
De início fez-se um levantamento de que tipos de dados foram produzidos no PA-SALV-C/IV e de como eles estavam organizados.

Os relatórios, por exemplo, estão publicados no formato público PDF, da Adobe. Esta escolha foi sedimentada na facilidade de difusão da informação neste formato sem que se corra o risco de descaracterização e até mesmo de adulteração do arquivo fonte. Os arquivos são compactos e mantêm a formatação original, o que os tornam perfeitos para serem descarregados (dowload) e impressos pelo usuário, além de poderem ser consultados na tela, onde oferecem também várias opções de interatividade. A leitura e impressão dos relatórios neste formato podem ser feitas com o Acrobat, programa distribuído gratuitamente e facilmente encontrado na Internet.

As informações de cunho cartográfico foram organizadas de duas formas. A primeira, ao longo dos relatórios ilustrando aspectos técnicos. Nesta vertente foi produzido um volume à parte (UHE Corumbá IV: cartografia de sítios arqueológicos), mostrando a cartografia dos sítios trabalhados. Esses produtos foram gerados no Corel Draw e posteriormente convertidos no formato PDF. A segunda, em um ambiente de SIG, onde os dados foram primeiramente estruturados no AutoCadMap e posteriormente integrados pelo ArcGIS, gerando o SIG Corumbá IV. No AutoCadMap foi construída a topologia necessária para integrar as informações geográficas com as não geográficas e no ArcGIS foi estruturado o SIG propriamente dito. A escolha destes programas está vinculada à disponibilidade e ao conhecimento técnico do funcionamento e da potencialidade de ambos.

No SIG Corumbá IV existem planos de informação relativos aos dados arqueológicos (sítios, ocorrências e pontos percorridos), à hidrografia, aos municípios, às zonas geoarqueoambientais, às estradas e a altimetria (mapa hipsométrico e de declividade). A estes planos de informação estão vinculados dados textuais. No caso dos sítios e ocorrências, informações como nome do proprietário e do local, coordenadas (geográficas e UTM), estado de conservação, classificação tipológica (lítico, lito-cerâmica e histórico), proximidade cultural, entre outras, estão disponíveis. Estas informações permitem que se façam alguns cruzamentos simples gerando, por exemplo, mapas 
temáticos onde os sítios segundo suas tipologias estão associados à hidrografia, às estradas e aos municípios (figura 23), ou onde os sítios segundo sua proximidade cultural estão associados à hidrografia e às zonas geoarqueoambientais (figura 24), ou ainda, sítios classificados pelo seu nível de degradação associada à declividade (figura 25) ou a hipsometria (figura 26). A geração de mapas temáticos pelo ArcGIS é algo que depende apenas de quais as informações estão disponíveis e de como queremos que as associações se processem.

A associação com bancos de dados externos é possível e em princípio se pensou em utilizar o banco de dados do SGPAB. Entretanto as fichas de cadastro dos sítios do PA-SALV-C/IV foram produzidas no editor de texto Word e não no formulário do Access. Este detalhe inviabilizou a ligação com os dados da ficha e decidiu-se selecionar algumas informações consideradas importantes para alimentar o banco de dados interno do ArcGIS. 


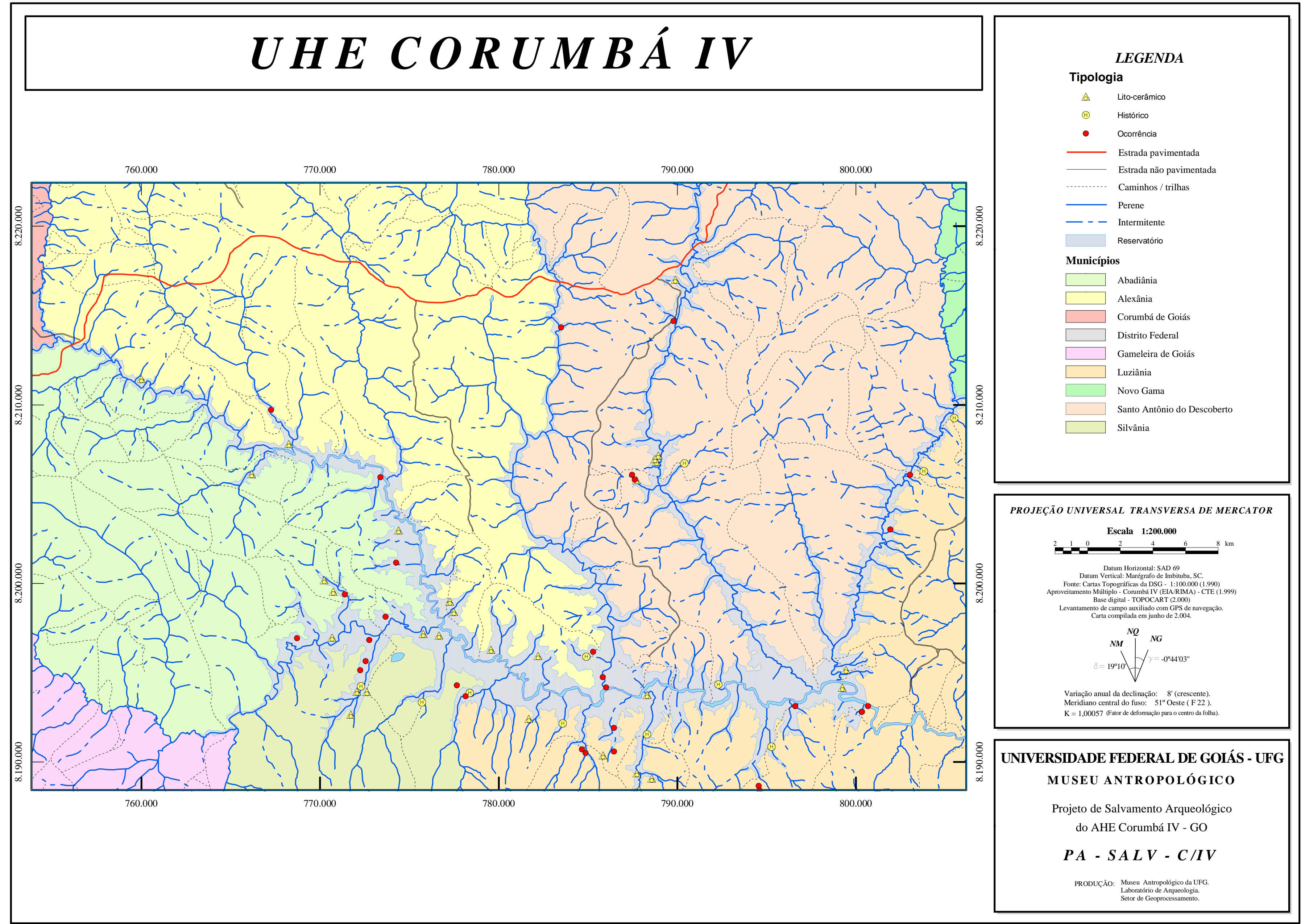

Figura 23 - Classificação dos sítios arqueológicos segundo sua tipologia. PA-SALV-C/IV. 


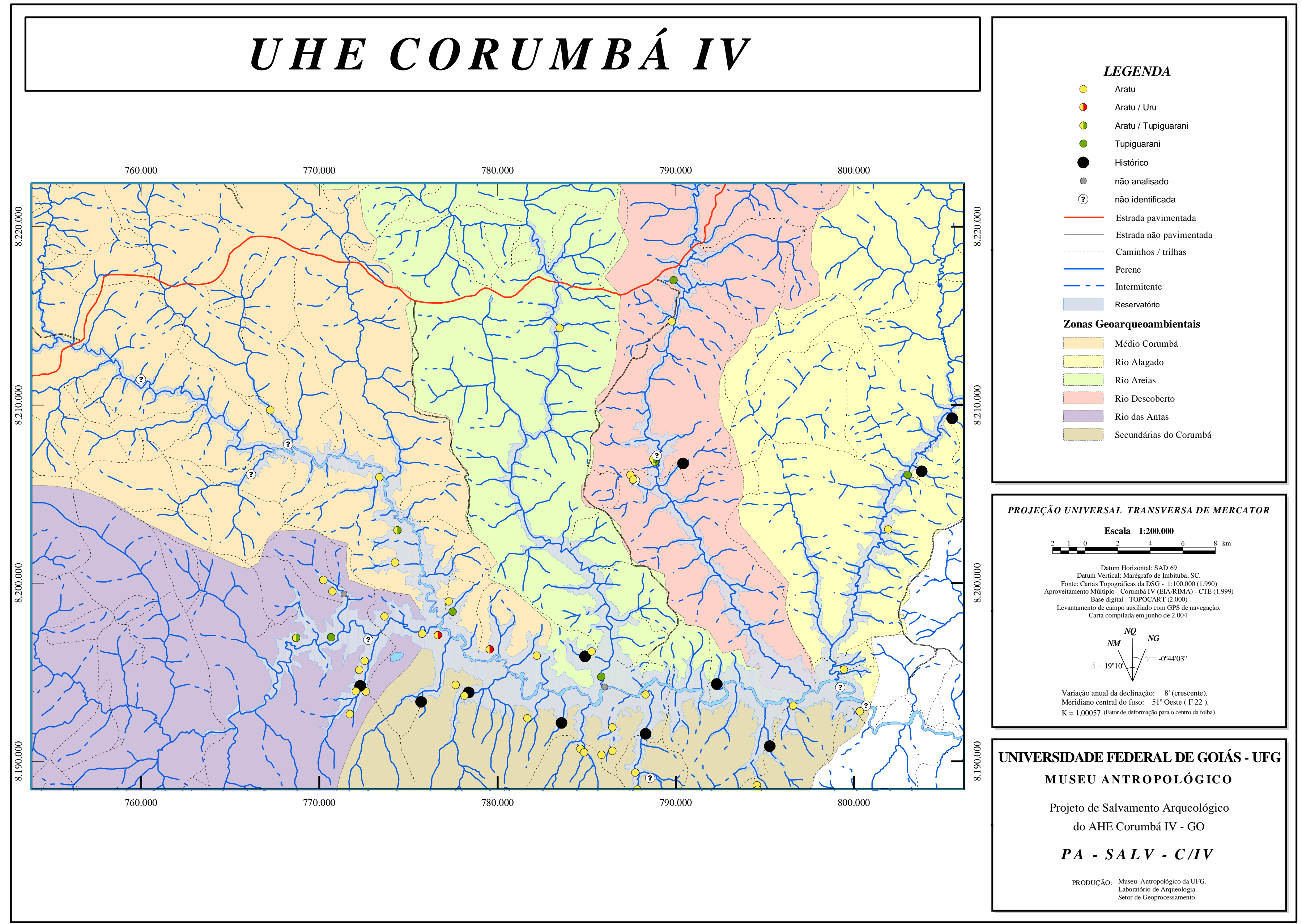

Figura 24 - Classificcação dos sítios arqueológicos segundo sua proximidade cultural. PA-SALV-C/IV. 


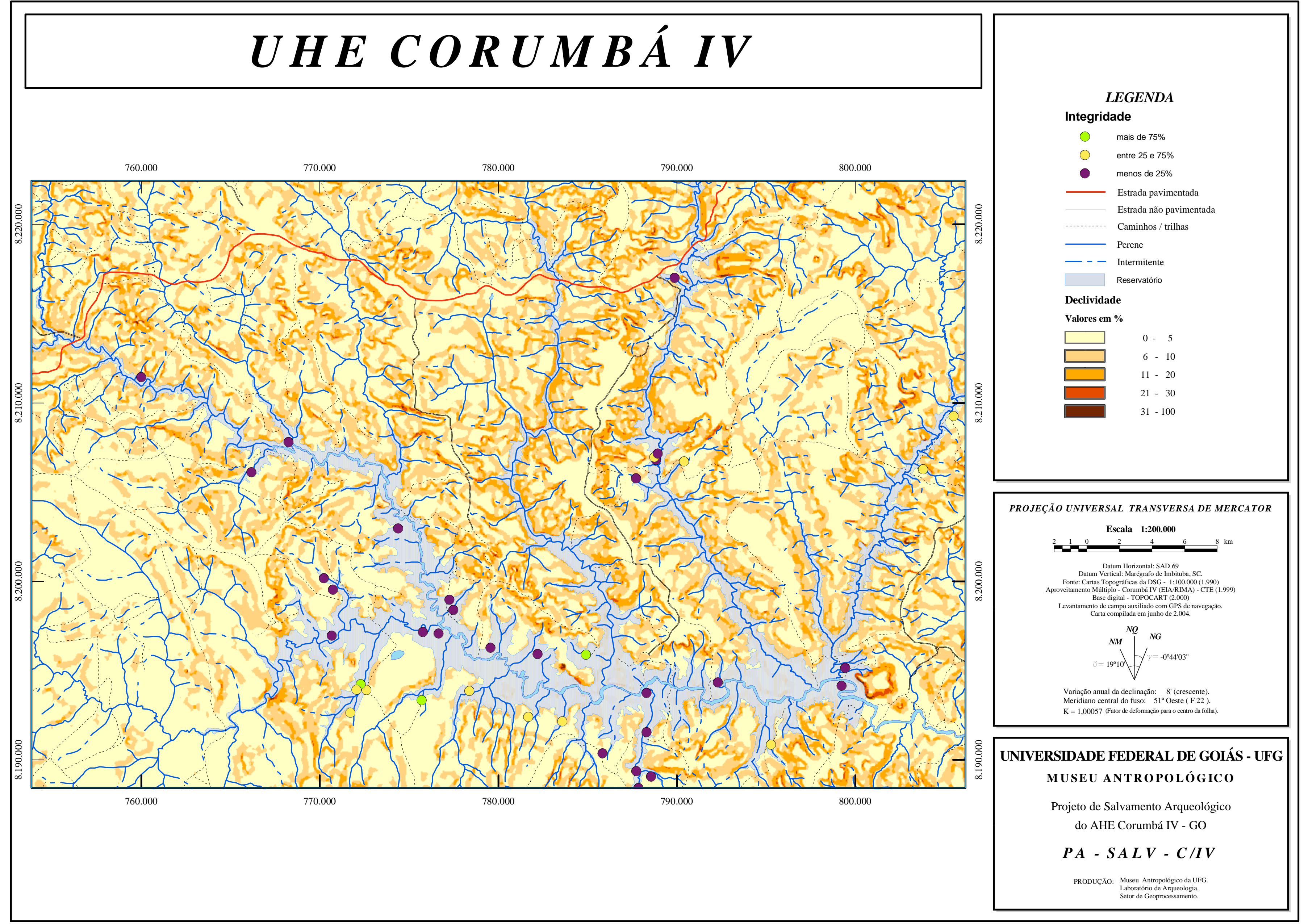

Figura 25 - Classificação dos sítios arqueológicos segundo seu grau de degradação versus declividade. PA-SALV-C/IV 


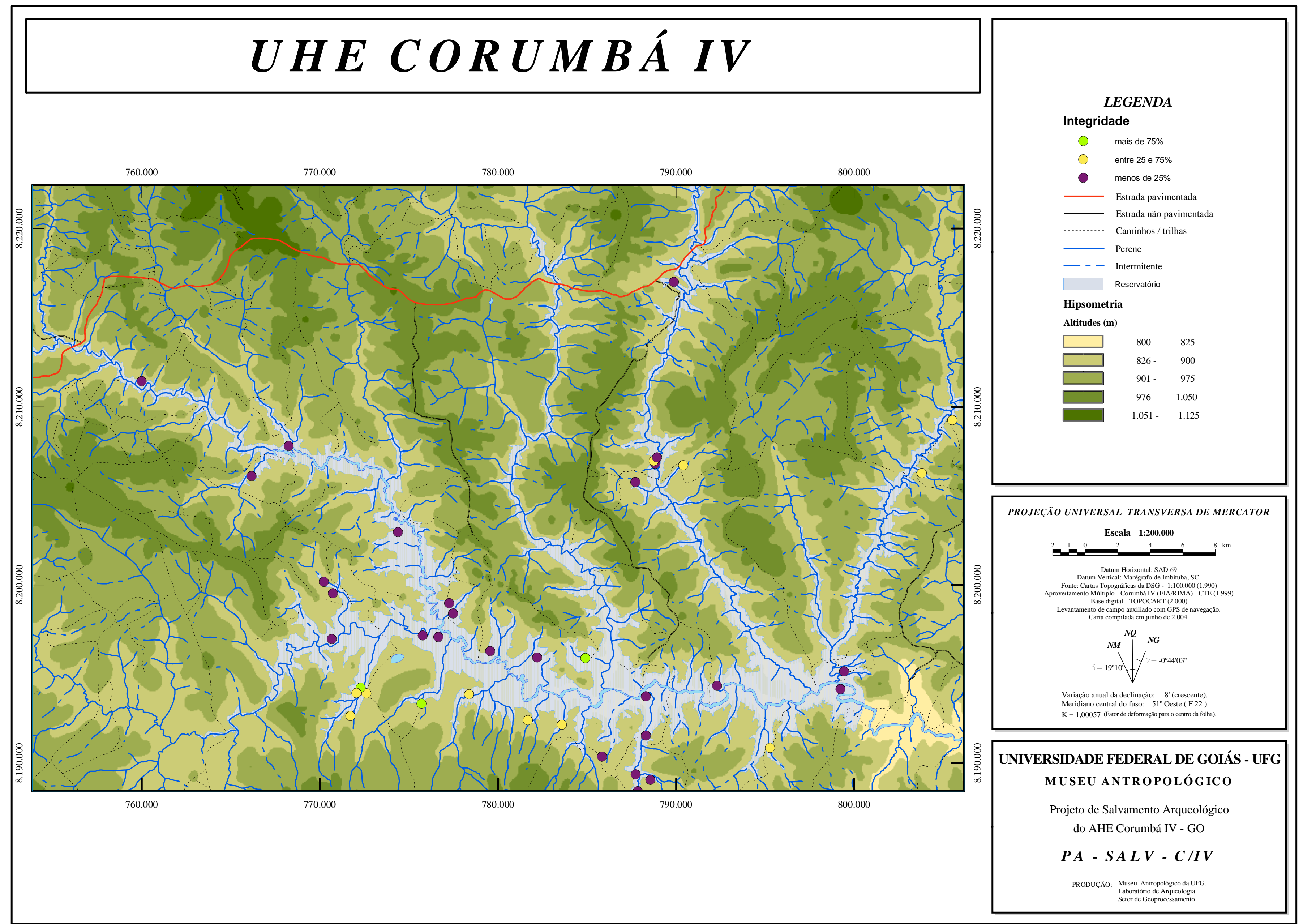

Figura 26 - Classificação dos sítios arqueológicos segundo seu nível de degradação versus hipsometria. PA-SALV-C/IV. 


\section{5 - SIG Arqueologia: aplicação em pesquisa arqueológica.}

A partir da análise do que já estava pronto, partiu-se para o estudo de como estas informações e outras mais poderiam ser integradas. Desta premissa, concebeu-se um sistema multimídia/SIG designado por SIG Arqueologia onde o usuário tem acesso às informações por caminhos diferentes, segundo o seu interesse.

Inicialmente, o SIG Arqueologia permite que o usuário acesse as informações contidas no relatório do PA-SALV-C/IV abrindo os arquivos originais no formato PDF. Este recurso é acionado por estrutura de menus interativos (figura 27) e foi desenvolvido utilizando-se o Dreamweaver (Macromidia), que é um software de construção de páginas para Internet. Dentro desta linha estão disponíveis os 4 relatórios técnicos do projeto, e um quinto volume da produção cartográfica (UHE Corumbá IV: cartografia de sítios arqueológicos).

A escolha de um único produto concebido no quarto volume se deveu, principalmente, à disponibilidade de espaço. O relatório completo do PA-SALV-C/IV ocupa 624 Mbytes e o SIG Corumbá IV outros 167 Mbytes. Este volume de informações não cabe num CD Rom e a possibilidade de se utilizar DVD, como mídia básica, tornaria o produto final restritivo à maioria dos usuários potenciais, o que confronta com a idéia original.

No segundo volume, que é referente às fichas de cadastro de sítios, foram incluídos links (figura 28) de modo que a partir delas é possível abrir os arquivos das fotografias (figura 29), dos mapas de localização (figura 30) ou do modelo digital de terreno (figura 31). Este recurso permite que o usuário tenha a qualquer tempo um visão espacial das descrições textuais da ficha. 


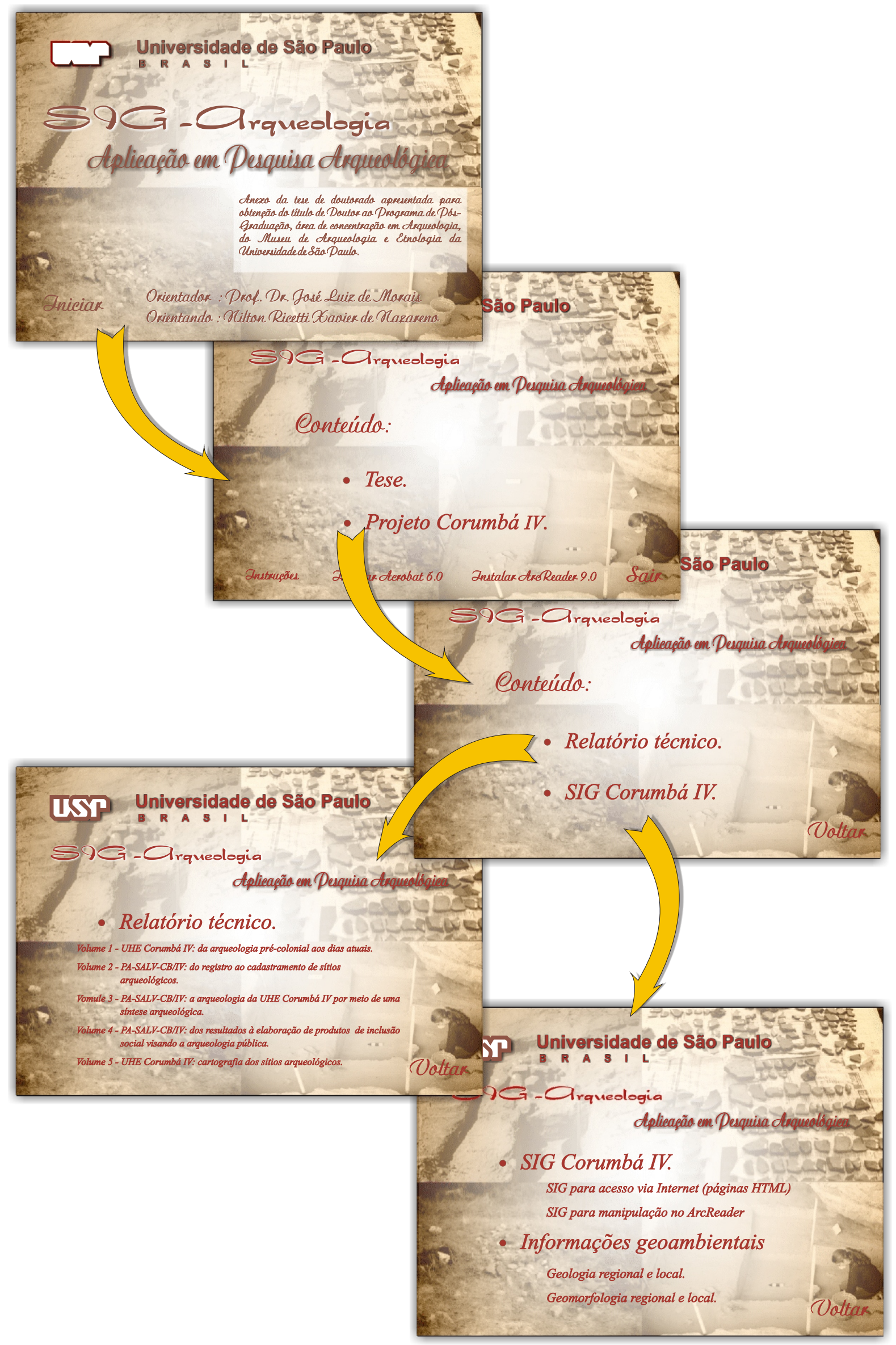

Figura 27 - Menus interativos do SIG Arqueologia. 


\begin{tabular}{|c|c|c|c|}
\hline $\begin{array}{l}\text { MINISTÉRIO } \\
\text { DA CULTURA }\end{array}$ & $\begin{array}{l}\text { FICHA DE REGISTRO DE } \\
\text { SITIO AROUEOLÓGICO }\end{array}$ & IPHAN & $\begin{array}{lrr}\text { Instituto } & \text { do } & \text { Patrimônio } \\
\text { Histórico } & \text { e } & \text { Artístico } \\
\text { Nacional } & & \end{array}$ \\
\hline $\begin{array}{l}\text { Sistema Nacional de Informações } \\
\text { Culturais - SINIC }\end{array}$ & & Depar & $\begin{array}{l}\text { to de Identificação e } \\
\text { nentação - DID }\end{array}$ \\
\hline
\end{tabular}

\begin{tabular}{l}
\hline Nome do sítio: \\
Sítio Fazenda Paulista II
\end{tabular}

Outras designações e siglas:

GO-Ca.60

Município: Luziânia

Localidade:

Fazenda Paulista. Margem esquerda do Rio Alagado.

CNSA: (campo reservado)

Outras designações da localidade:

Mesorregião: Leste Goiano

Microrregião: Entorno de Brasília

\section{Descrição sumária:}

Sítio arqueológico-histórico, do tipo fazenda, implantado a céu-aberto que, de conformidade com a classe de conservação, foi classificado como razoavelmente conservado. No sítio foram identificadas estruturas fazendárias correspondentes ao período de colonização do estado de Goiás, século XIX. Essas estruturas estavam representadas por área habitacional que teve a fachada do partido arquitetônico completamente alterada, muro-de-pedra e erguido em adobe com cobertura de telha; área de engenho, mal conservada, rego d'água contendo parcela da bica, curral; segmento arquitetônico; canal e fornalhas. As intervenções no sítio, de médio porte, caracterizaram as etapas de levantamento, de prospecção e de escavação de sítio arqueológico. O tipo de intervenção realizada compreendeu: o levantamento topográfico da área de implantação do sítio; o georreferenciamento das estruturas arqueológicas e das construções edificadas mais recentemente; o registro fotovideográfico do sítio e do seu contexto de ambientação; a elaboração de desenhos-técnico das estruturas edificadas e dos testemunhos relevantes para a compreensão da área de estudo; a abertura de corte de verificação e de trincheira e delimitação de área destinada à escavação e escavação; o levantamento da história oral da fazenda e o registro de objetos, remanescentes da produção da fazenda. Foram coletados na escavação artefatos de metal, telha, artefato de madeira e vidro. Amostras de sedimento, também, foram coletadas. A área próxima ao sítio, constituída pelo quintal da casa-sede, na época da pesquisa, era utilizada para o cultivo de milho. As demais áreas que integram a fazenda eram aproveitadas com pastagem. Destaca-se a existência de draga usada para a retirada de areia no Córrego do Açude que deságua no Rio Alagado.

\section{Sítios relacionados:}

Física: GO-Ca.59 - Sítio Fazenda Paulista I - 3,43Km de distância.

Cultural: GO-Ca.58 - Sítio Coruja; GO-Ca.59 - Sítio Fazenda Paulista I; GO-Ca.61 - Sítio Fazenda Lagoinha; GO-Ca.67 - Sítio Sabiá; GOCa.68- Sítio Fazenda São Bernardo; GO-Ca.70 - Sítio Ema; GO-Ca.76 - Sítio Fazenda Corumbá; GO-Ca.78 - Sítio Fazenda Buriti Madeira; GO-Ca.81 - Sítio Fazenda Cervo; GO-Ca.84 - Sítio Fazenda Engenho Velho.

\section{Nome do proprietário do terreno:}

Nelson Meirelles

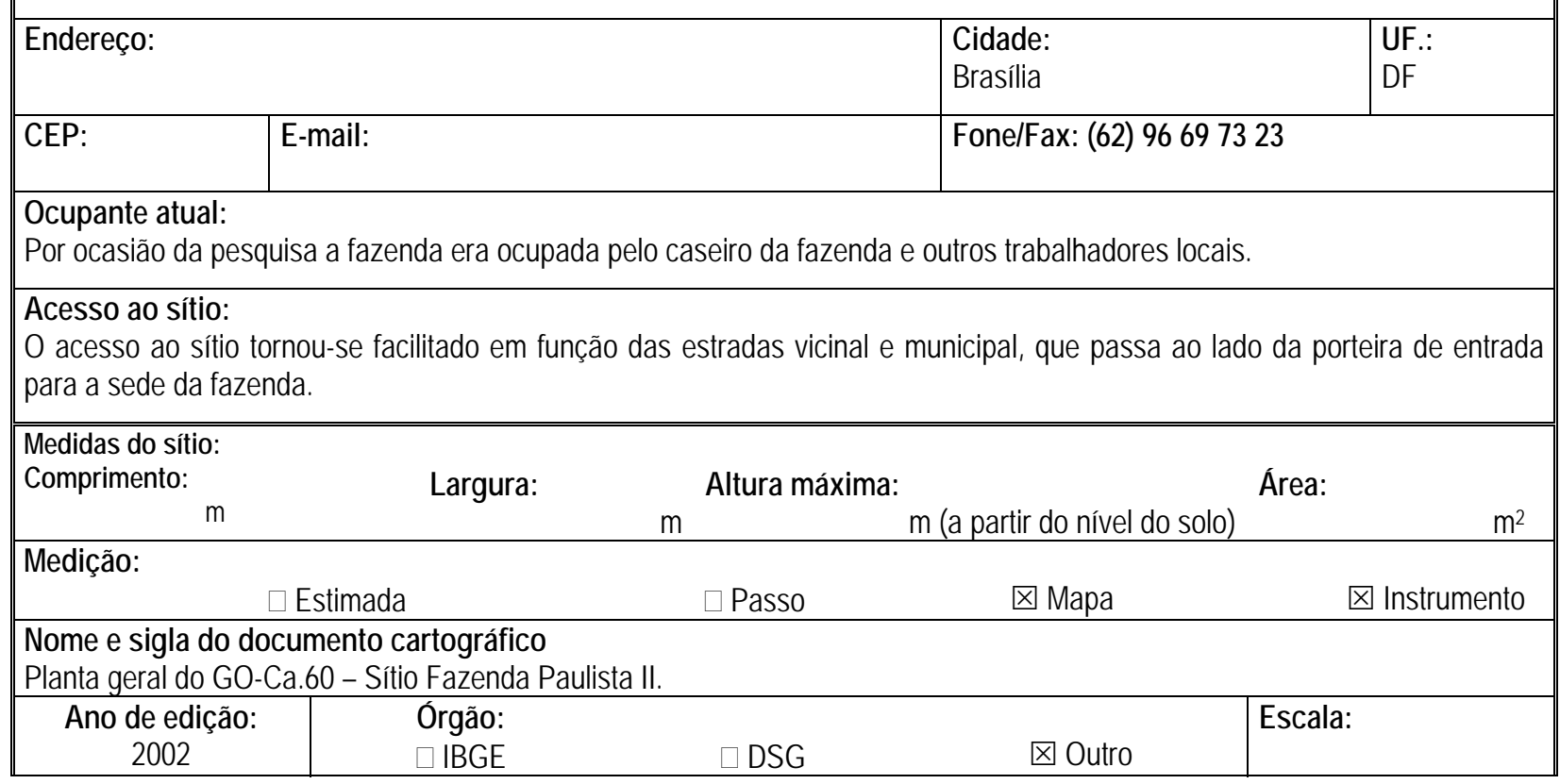

Figura 28 - Links adicionados às fichas de cadastro de sítios. 


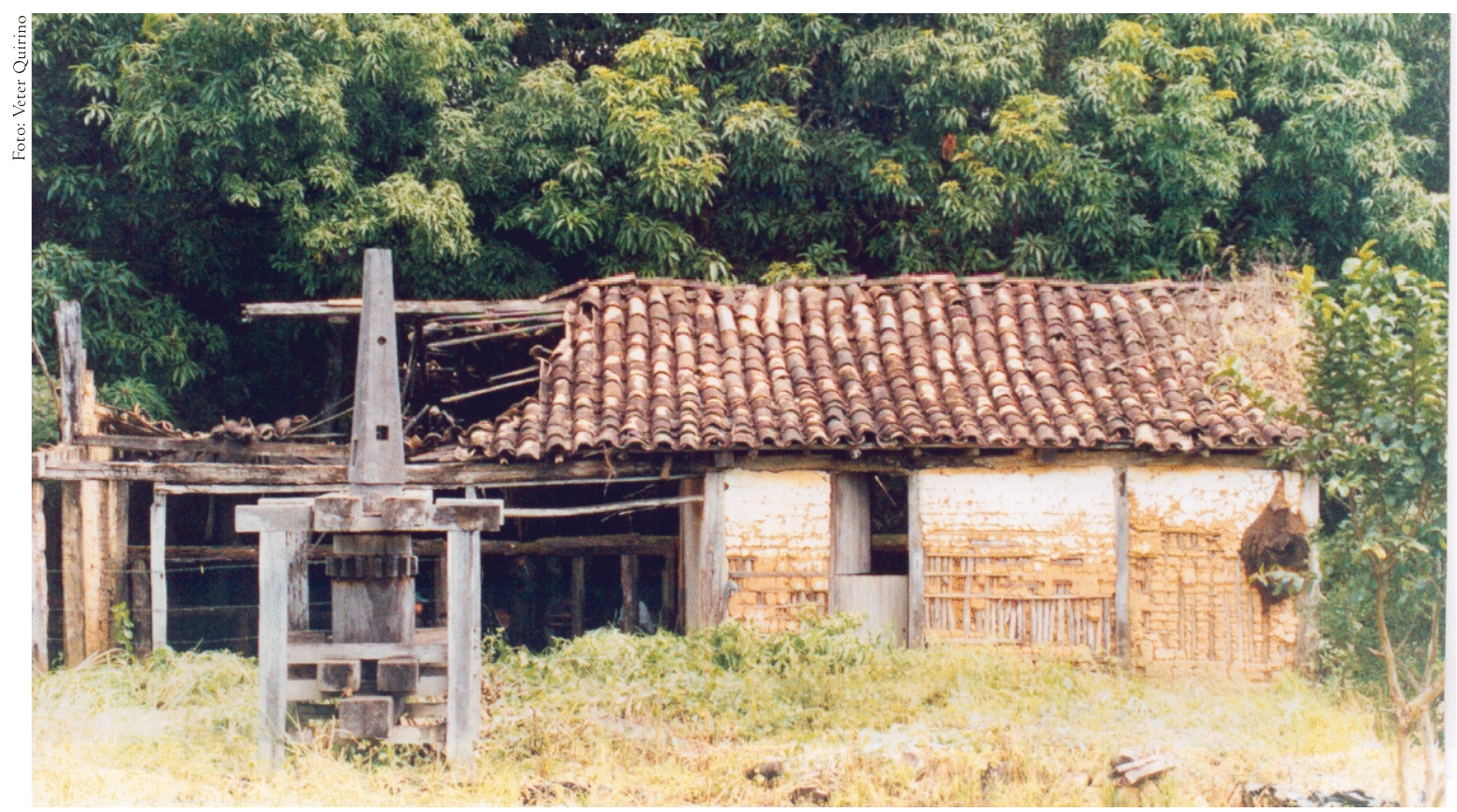

Vista geral externa da casa do engenho de cana-de-açúcar, remanescente de registro arqueológicohistórico, do tipo fazenda goiana do século XIX, localizado no GO-Ca.60 Sítio Fazenda Paulista II, margem esquerda do Rio Alagado, município de Luziânia, estado de Goiás, Brasil.

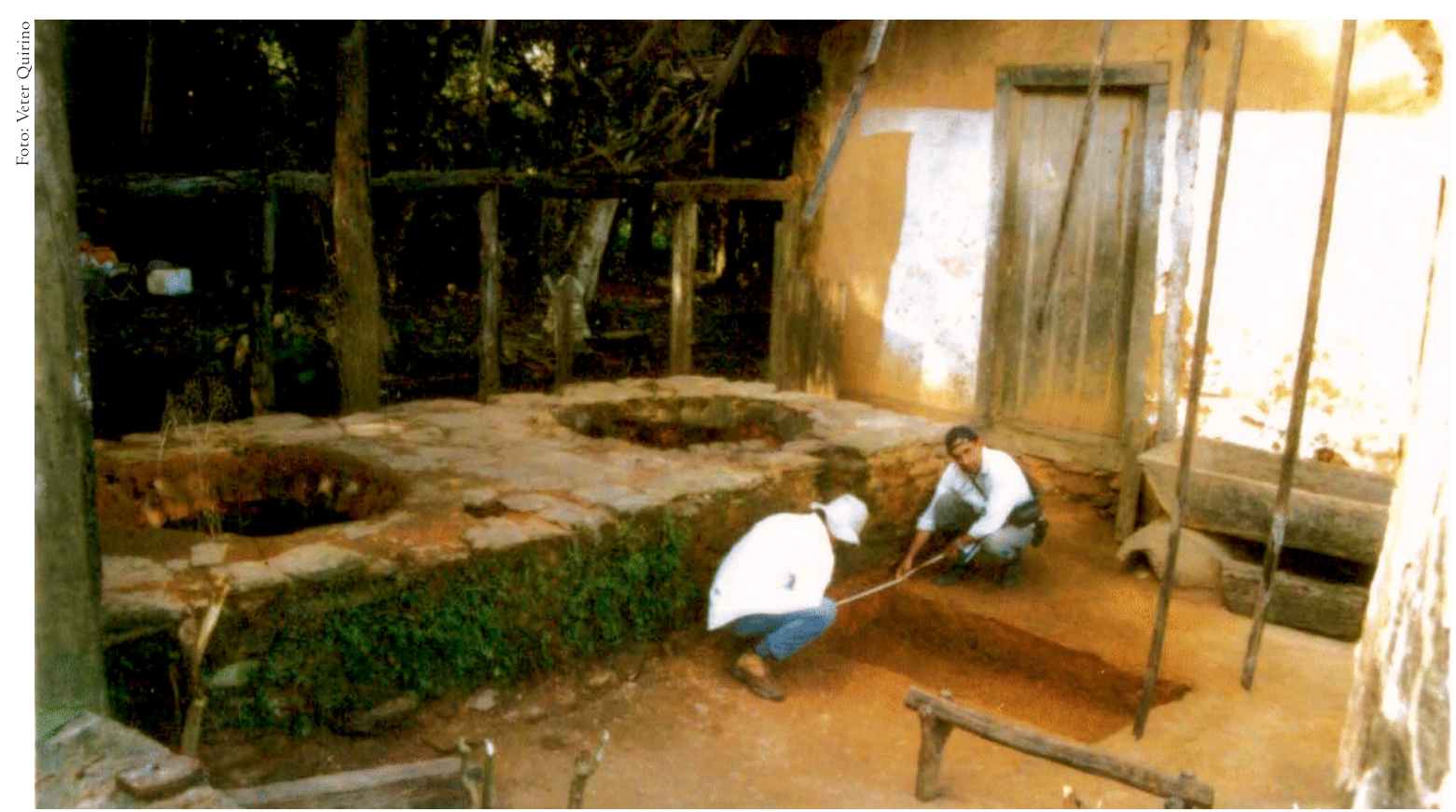

Aspecto geral da área de escavação aberta no interior da casa do engenho de cana-de-açúcar do registro arqueológico-histórico, GO-Ca.60 Sítio Fazenda Paulista II, situado na margem esquerda do Rio Alagado, município de Luziânia, estado de Goiás, Brasil.

Figura 29 - Imagens fotográficas ativadas pelo link da ficha de cadastro de sítios. 

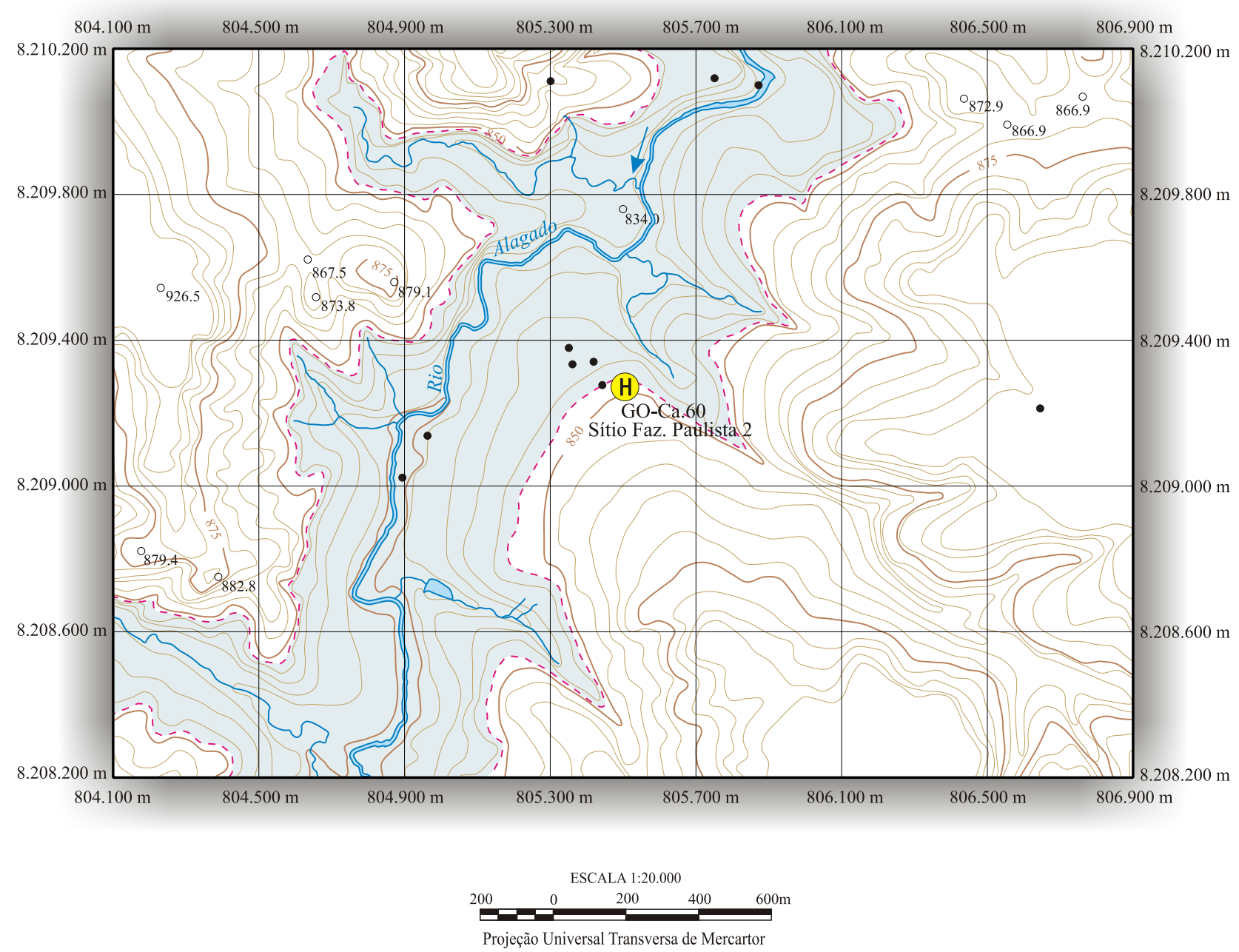

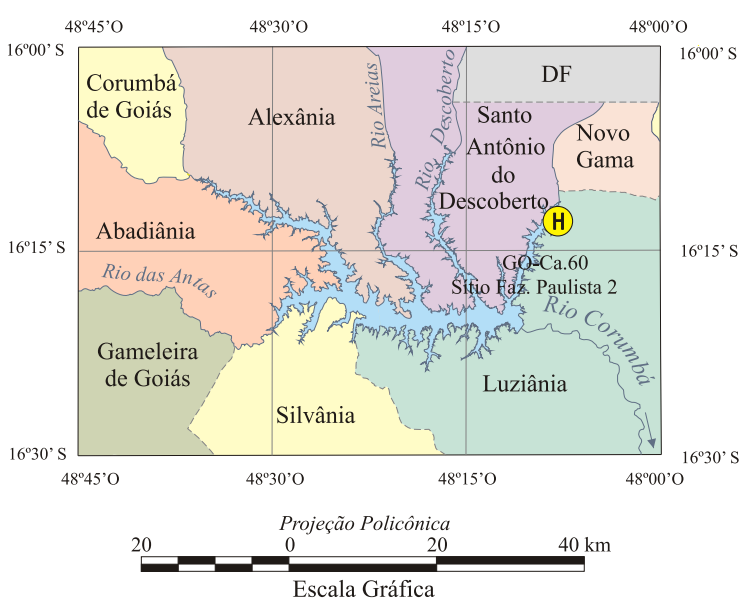

Localização do Sítio Faz. Paulista 2 (GO-Ca.60)

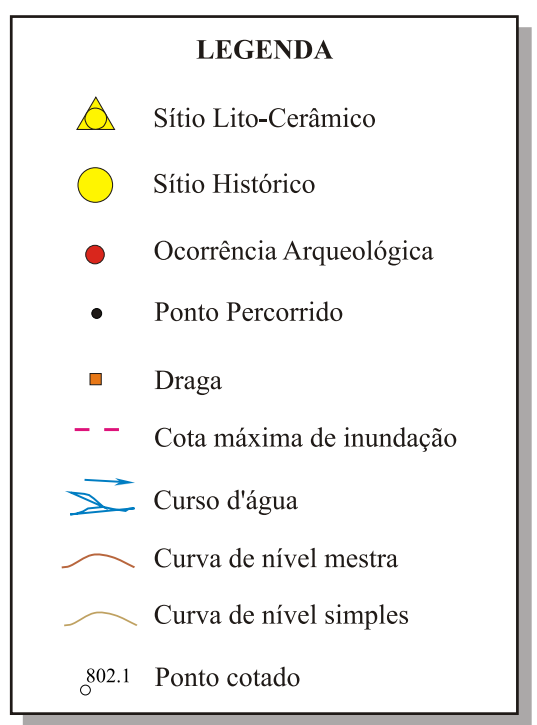

Produção: Museu Antropológico da UFG/Laboratório de Arqueologia/Setor de Geoprocessamento

Figura 30 -Planta de localização ativada pelo link da ficha de cadastro de sítios. 


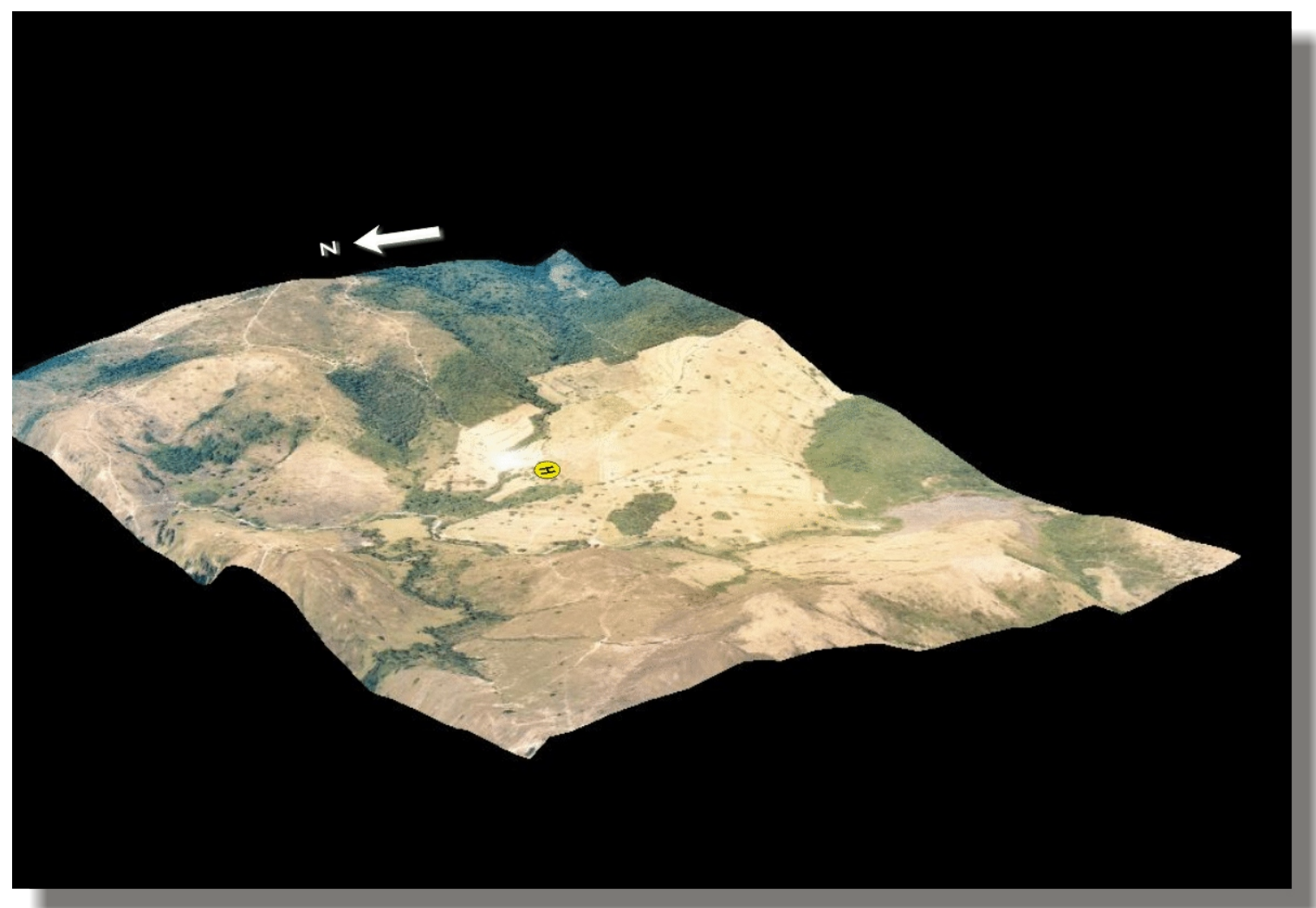

ÁREA RECOBERTA 6 km²
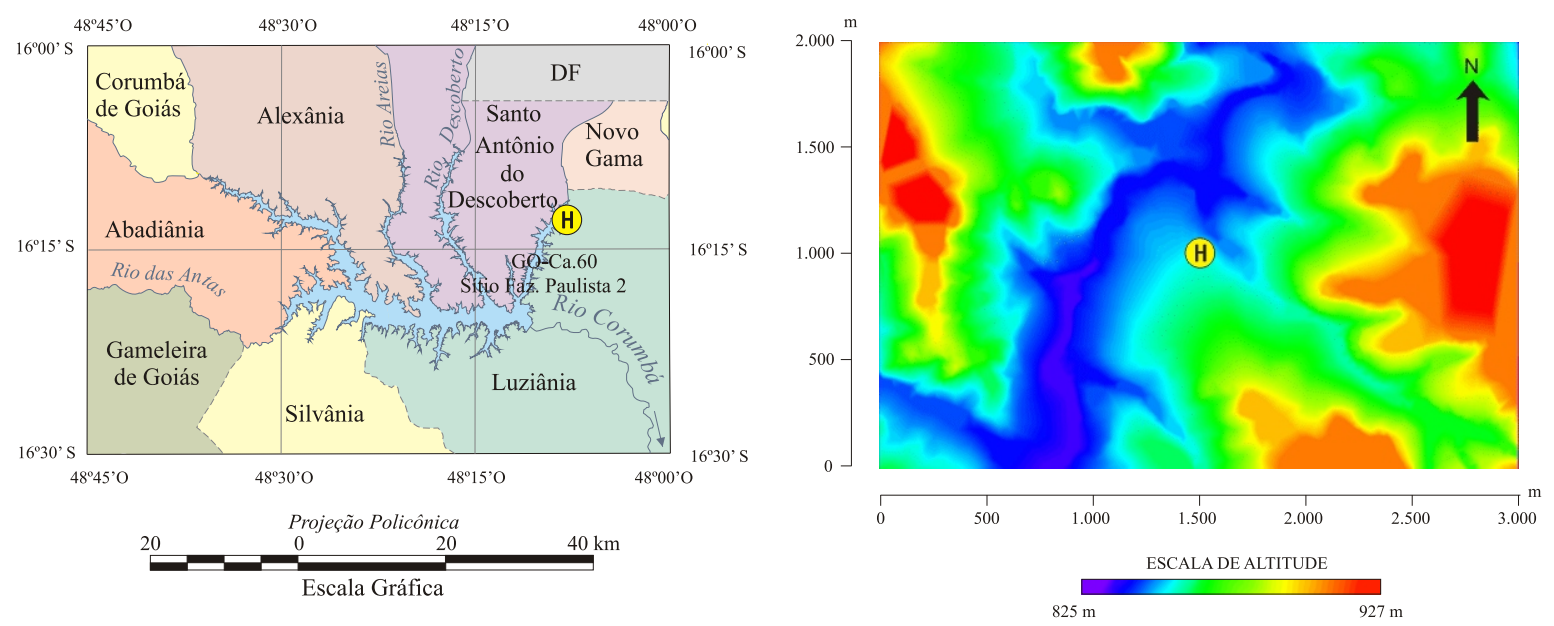

Vista Tridimensional do Sítio Faz. Paulista 2 (GO-Ca.60)

Produção: Museu Antropológico da UFG/Laboratório de Arqueologia/Setor de Geoprocessamento

Figura 31 - Modelo digital de terreno ativado pelo link da ficha de cadastro de sítios. 
Considerando o universo heterogêneo de usuários, projetaram-se três formas de acesso ao SIG Corumbá IV, segundo o nível de familiaridade de cada um com a tecnologia de SIG. Para usuários com pouca ou nenhuma experiência, o sistema funciona utilizando o Internet Explorer como base. Nesta solução foi utilizado um aplicativo denominado ImageMapper, desenvolvido pela empresa alemã Alta4 Geoinformatik AG (www.alta4.com) que transforma os planos de informação do ArcGIS em páginas de Internet (html) para publicação on line. Quando instalado esse programa atua como uma opção de comando do ArcGIS, aparecendo no seu menu interno.

No caso daqueles com alguma familiaridade, o SIG Arqueologia, permite um outro tipo de interação através do programa ArcReader, um visualizador desenvolvido pela ESRI para o ArcGIS. Este produto é de distribuição gratuita e pode ser encontrado no endereço eletrônico da empresa (http:www.esri.com).

Finalmente, para usuários mais avançados, desde que ele possua o ArcGIS (versão 8.3), é possível acessar as informações do SIG Corumbá IV inseridas no CD e fazer novos cruzamentos e interações, segundo o seu interesse.

Para o usuário principiante, conforme esclarecido acima, utilizou-se o aplicativo ImageMapper que a partir de um projeto de SIG do ArcGIS, gera páginas html. O programa inicialmente cria uma série de arquivos no formato JPG (formato raster) do mapa como um todo e de partes deste, para possibilitar uma visualização próxima (zoom). Em seguida são geradas, automaticamente, páginas html vinculadas às imagens. É nestas páginas que o sistema faz os vinculamentos com as informações não textuais do banco interno do ArcGIS. Se no projeto do SIG houver algum link externo, este será preservado. É importante ressaltar que o programa cria para cada vínculo uma página html. É gerada ainda uma página índice que organiza todo o sistema. Essa solução simples é extremamente interessante para divulgação de informações pela Internet. Na figura 32 está mostrado de forma esquemática como a vinculação é processada. 


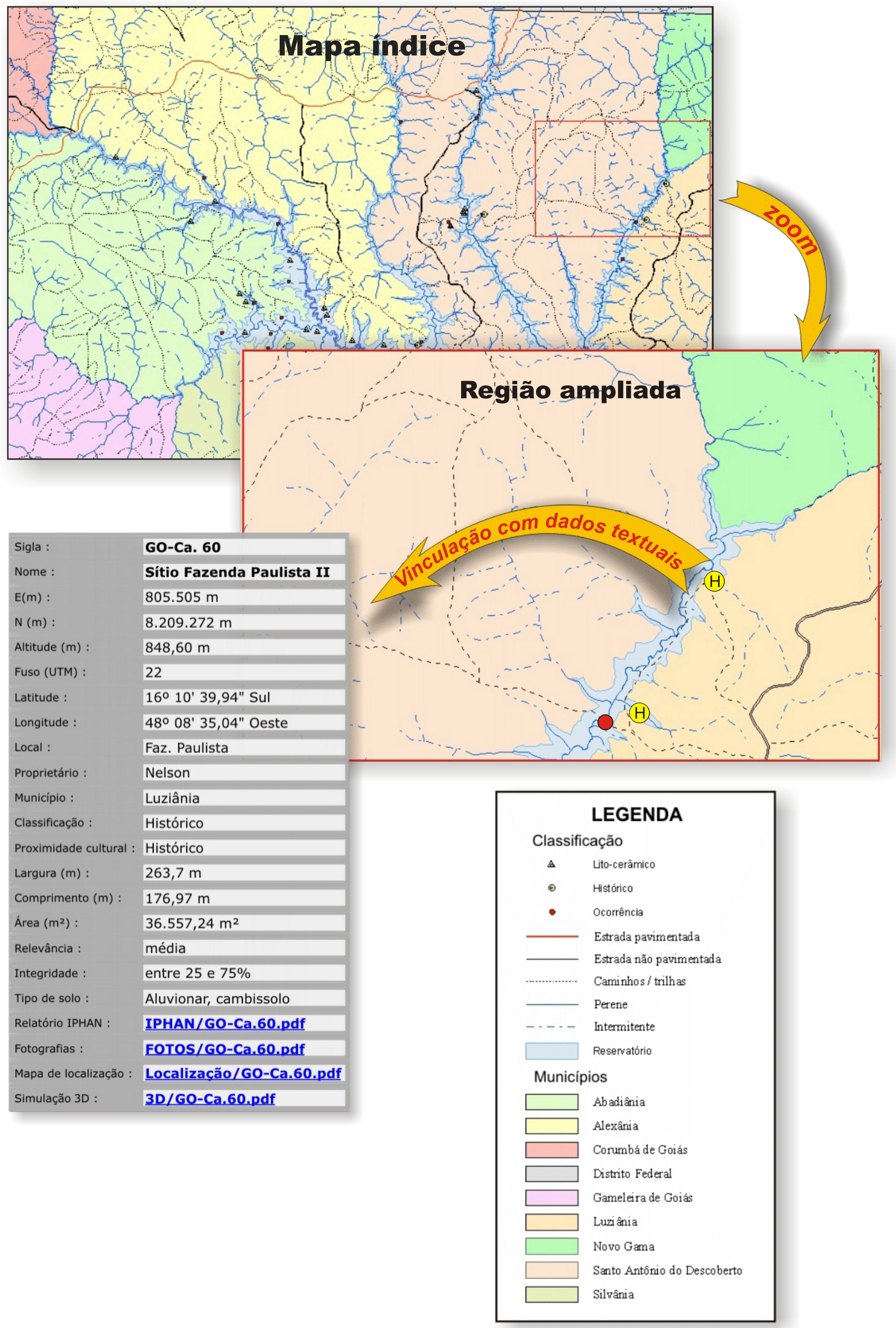

Figura 32 - Forma de vinculação efetuada pelo ImageMapper. 
O ImageMapper cria automaticamente os arquivos e os subdiretórios necessários ao funcionamento do sistema e por razões de projeto, independentemente do SIG que estiver sendo convertido, alguns arquivos e diretórios são criados com os mesmos nomes. Outra característica importante diz respeito aos planos de informação, que uma vez escolhidos, não podem ser alterados. Esse fato fez com que fossem idealizados três conjuntos de planos de informação para serem visualizados pelo sistema. Nos três conjuntos os planos relativos à hidrografia e sistema viário estão presentes, podendo-se, por exemplo, obter informações sobre o nome do curso d’água, sua hierarquia, sub-bacia e bacia regional, com um simples toque sobre a entidade com o cursor do mouse. Com respeito aos outros planos de informação, optou-se por associá-los com:

- municípios e Arqueologia segundo a classificação em sítios líticos, lito-cerâmicos e históricos e ocorrências arqueológicas.

- zonas geoarqueoambientais e arqueologia segundo sua proximidade cultural em tradições Aratu, Aratu-Uru, Aratu-Tupiguarani, Tupiguarani, não identificado, não analisado e histórico.

- Declividade e arqueologia segundo o estado de concervação dos sítios em mais de $75 \%$, entre $25 \%$ e $75 \%$ e menos de $25 \%$.

Para que esta idéia fosse concretizada foi necessário escolher esses planos de informação no ArcGIS e posteriormente acionar o ImageMapper. A cada vez que foi executado o programa, modificou-se o nome do sub-diretório raiz de modo que um novo processamento não apagasse o anterior.

Finalizada a criação dos três conjuntos foi necessária a construção de uma página html índice, para acionar cada uma das possibilidades. O plano de informação da hipsometria foi utilizado como fundo e com o Dreamweaver foram gerados os links necessários. Esta página é ativada pelo menu do sistema. 
Com respeito às informações disponíveis no sistema, além das de interesse arqueológico imediato, este foi dotado de alguns elementos suplementares. Aos municípios adicionou-se a informação constante no senso 2002 e o levantamento bibliográfico histórico de alguns e, às zonas geoarqueoambientais, os relatórios descritivos de cada uma. Foram apensadas também, as descrições geológicas e geomorfológicas local e regional da área compreendida pelo empreendimento. Nas tabelas de cada sítio foram criados links similares aos das fichas do cadastro de sítios, de modo que também se pode vislumbrar as imagens fotográficas, os mapas de localização, o modelo digital de terreno, além da própria ficha de sítio. Por uma questão de arquitetura do ImageMapper foi necessário criar estes links três vezes, um para cada opção. Estes links podem ser visualizados na figura 32 onde aparecem na tabela de sítio na cor azul.

A outra opção de acesso ao sistema é conseguida com a instalação no computador do ArcReader, visualizador criado para sistemas desenvolvidos no ArcGIS. Como dito anteriormente, este programa é de distribuição gratuita, e deste modo, a sua instalação foi incluída no CD Rom (versão 9.0). Com respeito à instalação do software é necessário verificar se no computador não existe uma versão anterior do programa e proceder a desinstalação, se for o caso. O SIG Arqueologia foi desenvolvido no ArcGIS 8.3 e pode ser visualizado por ArcReader desta versão. Novamente é preciso lembrar que este programa só pode ser instalado em computadores cujo sistema operacional seja o Windows 2000 ou XP.

Nesta opção é possível escolher quais os planos de informação que se deseja associar para visualização. Contudo não se pode ir além do que foi programado em termos de cruzamentos. Este programa só permite que se visualize e faça buscas simples do tipo mostre o sítio GO-Ca. 60, ou medir distâncias entre pontos. A vantagem desta opção em relação à anterior é a qualidade visual e a possibilidade de impressão do material. No entanto não possibilita a geração de muitos links externos por plano de informação e nem a disponibilização na Internet. Quando se define por ativá-lo no SIG Arqueologia, aparece a mensagem como se um programa estivesse sendo baixado (download) . Isto ocorre porque ele está sendo aberto dentro de uma página html. Nesta situação basta mandar o sistema prosseguir. 
Por último, para usuários experientes, no CD Rom está disponível todo o projeto do SIG Corumbá IV, o que permite a introdução de novas informações, a criação de ferramentas de busca e cruzamentos, desenvolvidas em Visual Basic Aplication (VBA) e a criação de novos planos de informação. Para tanto é necessário que o usuário possua uma licença do ArcGIS 8.3 ou superior e tenha experiência com o software.

Em termos de concepção o sistema é funcional e em vários testes efetuados trabalha de acordo com o esperado. No entanto, em virtude do tamanho dos arquivos no formato PDF produzidos para os relatórios do PA-SALV-C/IV, o sistema opera melhor em computadores com boa capacidade de processamento e memória. Isto ocorre porque ao serem acionados os links que fazem referência a algum arquivo de relatório, o sistema operacional tem que acionar o programa de visualização ( Acrobat ), e este abre o arquivo escolhido. Para se ter uma idéia, o volume I do relatório ocupa 19 Mbytes de espaço em disco. No caso do ArcReader este é um programa relativamente "pesado" e exige um pouco mais do computador. Finalmente, para computadores onde o sistema presente não seja nem o Windows 2000 ou o XP, ainda existe a possibilidade de acessar os quatro volumes principais do relatório final, alguns relatórios extras sobre geologia, geomorfologia e o SIG baseado em páginas html.

Como parte integrante do SIG Arqueologia foi incluído ainda no CD Rom, o arquivo correspondente a esta tese para que outros usuários possam compartilhar do experimento.

O funcionamento esquemático do SIG Arqueologia pode ser observado na figura 33 e o conteúdo do CD Rom na figura 34. 


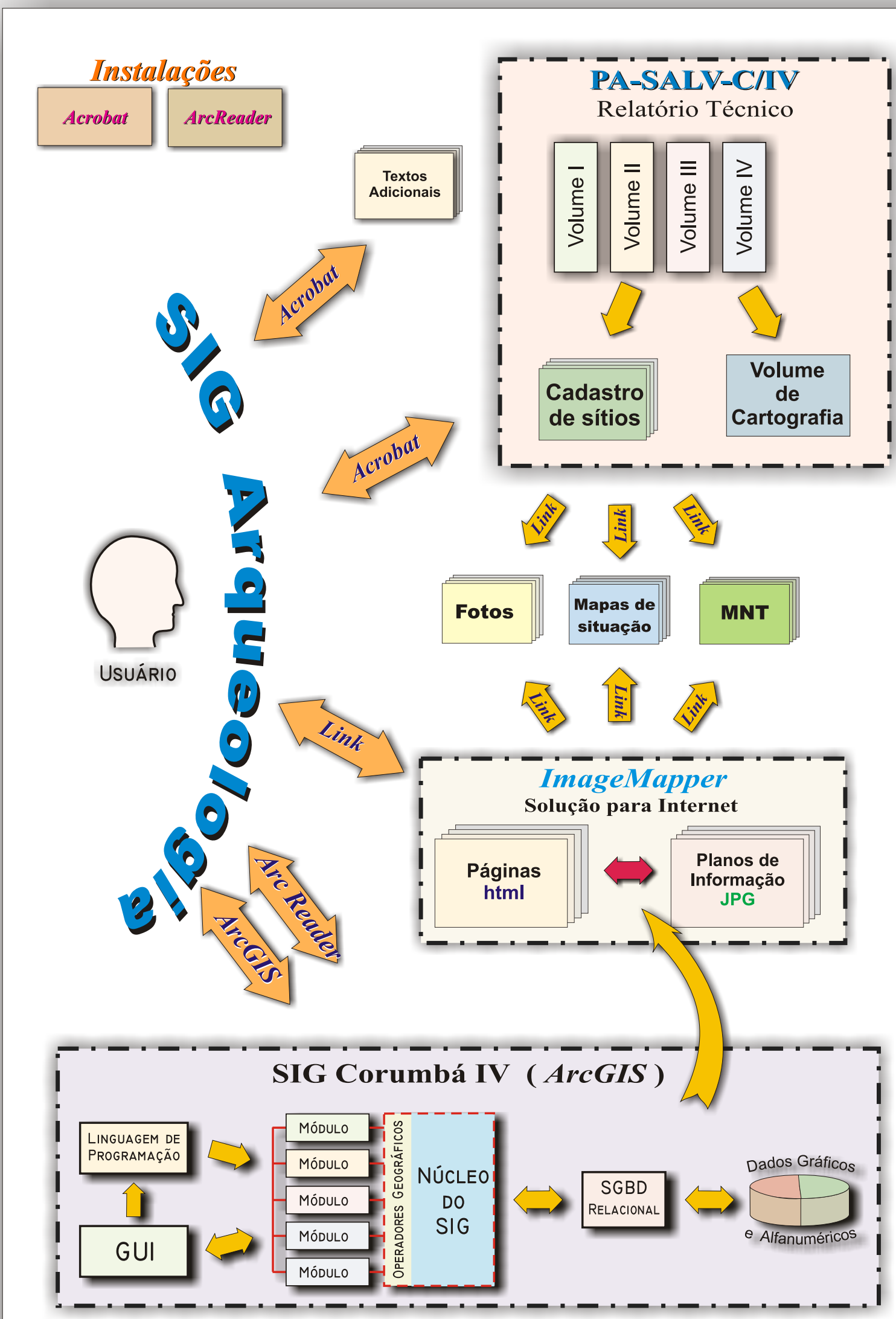

Figura 33 - Diagrama esquemático do SIG Arqueologia 


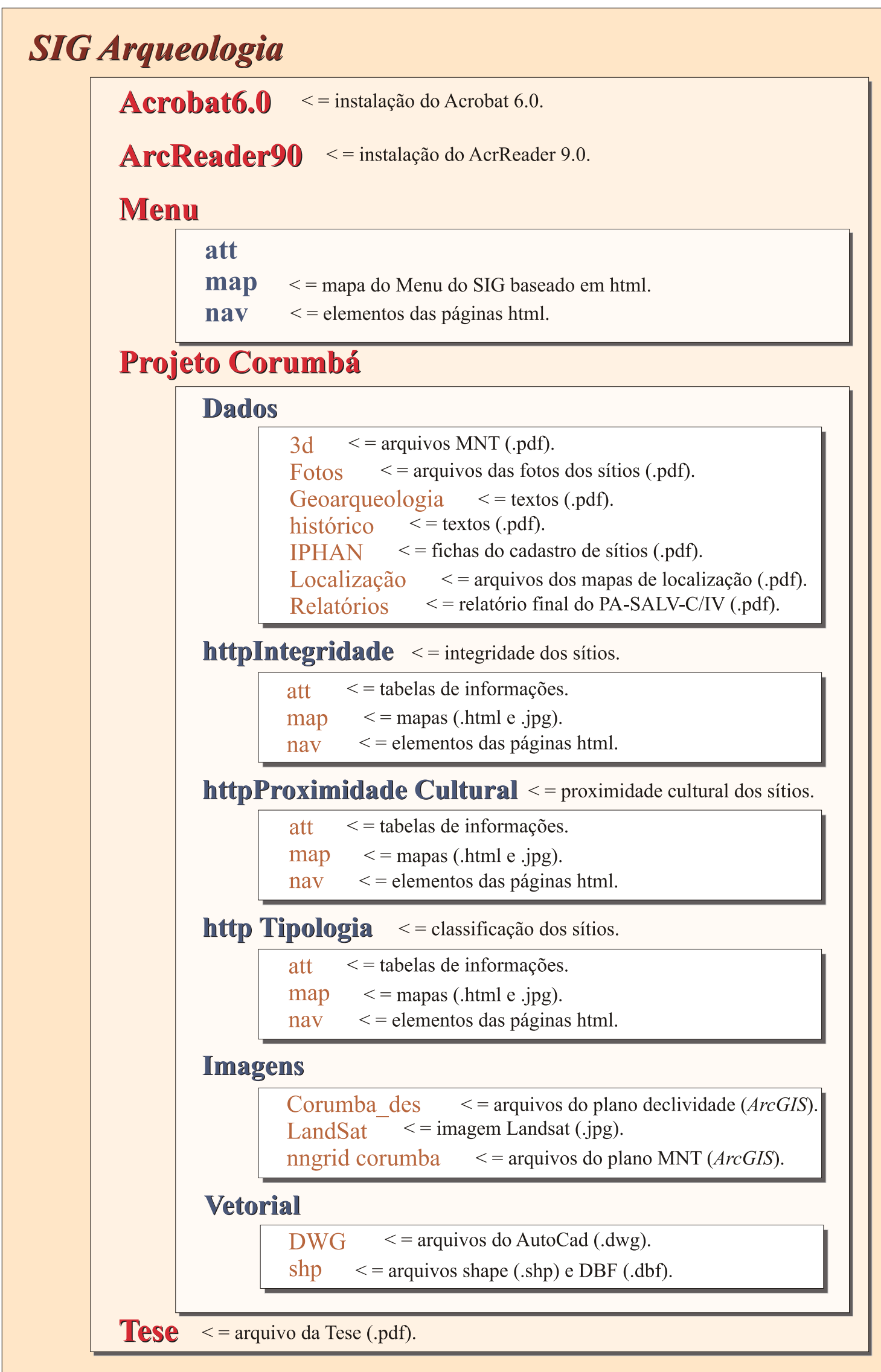

Figura 34 - Conteúdo do CD Rom SIG Arqueologia. 


\section{Capítulo IV - Conclusões e recomendações}

Os Sistemas de Informação Geográfica têm recebido um destaque importante nos últimos anos, principalmente com a crescente velocidade de processamento versus a diminuição paulatina dos custos dos computadores pessoais. Este fato tem levado vários usuários, nas mais diferentes áreas do conhecimento, a utilizar essa poderosa ferramenta de análise. Essa tendência mundial atinge inclusive a Arqueologia e, uma simples busca na Internet, mostra os inúmeros trabalhos produzidos com o seu auxílio.

No Brasil, entretanto essa realidade ainda está muito no início e poucos são os trabalhos encontrados. Esta situação provavelmente é assentada no fato de que os SIGs exigem um conhecimento um pouco mais profundo nas áreas da informática e da geomática $^{9}$. Esta circunstância pode ser corroborada quando se analisa os trabalhos de Thomas (2002) e Kneip (2004), onde o SIG é utilizado para finalidades distintas, mas a complexidade na adoção da tecnologia é visível.

Com respeito à produção de SIG preditivo ficou demonstrado que a idéia é bastante interessante, porém esbarra em aspectos técnicos. A concepção teórica do sistema é algo que exige experiência e conhecimento na área do geoprocessamento e, sobretudo de material cartográfico confiável e em escala adequada. Infelizmente a cartografia brasileira está em descompasso com a evolução da tecnologia, e isso tem frustrado alguns pesquisadores que imaginaram que a geração de mapas de potencial arqueológico fosse algo que só dependesse de software/hardware. Constata-se que o calcanhar de Aquiles do SIG preditivo em nosso País está muito mais centrado nos dados de cunho cartográfico do

\footnotetext{
9 Compreende atividades de produção, aquisição, armazenagem, análise, disseminação e gerenciamento de informações espaciais relacionadas com o ambiente e com os recursos terrestres. Inclui atividades de levantamento e mapeamento, integrando elementos como topografia, cartografia, hidrografia, geodésia, fotogrametria, agrimensura com as novas tecnologias e os novos campos de aplicação, como o sensoriamento remoto, o mapeamento digital, os sistemas de informações geográficas e os sistemas de posicionamento por satélite. Com dados coletados por sensores orbitais e aerotransportados por instrumentos acoplados em embarcações ou instalados no solo, uma vez processados e manipulados com equipamentos e programas da tecnologia da informação, geram-se produtos que podem constituir mapas dos mais diversos tipos ou bases de dados de cadastros multifinalitários.
} 
que nas altercações sobre modelo teórico adequado de representação da realidade, embora essa discussão seja importante.

Baena (2004), em seu artigo La Arqueologia peninsular y los SIG: presente y futuro, apresenta um parágrafo emblemático sobre esse assunto:

Los problemas básicos de un SIG están en la propia esencia de esta herramienta, y del márgen tan amplio de variación o versatilidad de algoritmos y estructuras de información que manejan. Todo proceso de abstracción de la realidad implica en mayor o menor medida la introducción de errores en el tratamiento de la información. Así por ejemplo, al comienzo de la histora de los SIG las resoluciones que las plataformas eran capaces de manejar eran muy limitadas, razón por la que los resultados obtenidos adolecían de escasa precisión. Esta imagen que hoy en día tenemos de los primeros trabajos elaborados en SIG es la que en un plazo de tiempo breve tendremos de lo que en la actualidad venimos realizando.

Esta citação mostra que a discussão sobre a problemática dos SIGs na Arqueologia é mundial e que o assunto merece mais pesquisas e experimentos. Modelos teóricos de representação da realidade precisam ser testados, afinal de contas, a pergunta da página 46 precisa ser respondida.

Um outro ponto importante diz respeito à falta de um compartilhamento mais eficiente dos dados das pesquisas arqueológicas realizadas no território nacional. Normalmente, a divulgação é feita em eventos científicos ou em revistas especializadas, como é de praxe. É pouco explorado o potencial da Internet. O próprio IPHAN tem enfrentado problemas na atualização do seu "Sistema de Gerenciamento do Patrimônio Arqueológico Brasileiro” (SGPAB) porque muitos pesquisadores simplesmente não preenchem a base de dados do programa e enviam as fichas de cadastro de sítios em um formato inadequado. É bem verdade que em certas circunstâncias as opções do formulário de cadastro para os sítios não contempla totalmente as necessidades dos pesquisadores, obrigando-os a adequar o formulário em outro software, mormente no Word. Este 
problema de caráter aparentemente administrativo tem provocado alguns inconvenientes quando se precisa pesquisar quais os sítios cadastrados em uma determinada região. Em alguns casos as informações estão desatualizadas ou não correspondem aos dados originais. Esta inconsistência foi verificada quando, na pesquisa via Internet no site do IPHAN, alguns itens sobre os sítios do Projeto de Salvamento Arqueológico da Usina Hidrelétrica Serra da Mesa (PA-SALV-SM) estavam em desacordo com os originalmente repassados.

Este fato demonstra a necessidade de uma ampla discussão sobre como reverter essa situação. Não é um problema que diga respeito unicamente ao IPHAN, mas à toda a sociedade e principalmente, aqueles que se ocupam com o estudo e a preservação do patrimônio arqueológico. Não é exagero lembrar que não se preserva aquilo que não se conhece e não se dá valor.

Neste trabalho se procurou demonstrar uma forma de divulgação dos resultados de uma pesquisa de salvamento arqueológico (Projeto de Salvamento Arqueológico da UHE Corumbá IV), onde rapidamente o usuário pudesse acessar as informações de seu interesse. Para isso foi utilizado um sistema híbrido onde multimídia e SIG estão associados, denominado SIG Arqueologia. O sistema multimídia permite que o usuário acesse as informações, porém sem a possibilidade de proceder a análises. Já na opção do SIG, pela própria acepção da palavra, têm-se disponíveis alguns recursos.

Uma análise um pouco mais profunda do sistema mostra que mesmo no ambiente de SIG , onde se esperaria uma liberdade maior de escolhas, isto não é possível, a não ser no caso onde o usuário tenha o ArcGIS e possa trabalhar diretamente na base de dados, alterando-a através da adição ou supressão de variáveis. Pelas limitações dos programas ArcReader e ImageMapper as informações foram disponibilizadas segundo a ótica de quem o concebeu.

Esta situação em nenhum momento invalida a idéia do uso do SIG na inclusão social, pois a possibilidade de se ver as informações espacializadas, enriquece 
sobremaneira o trabalho do pesquisador, mesmo que ele tenha que enxergar através da concepção de mundo de quem o produziu.

O SIG Arqueologia foi idealizado para funcionar em CD Rom, e desse modo se dotou o sistema de algumas facilidades, como os programas de instalação do Acrobart e do ArcReader, que podem ser ativados através do sistema de menus. Projetado para ser auto-executável ele funciona melhor em computadores com sistema operacional Windows 2000 ou XP, com processador Pentium IV ou Athlon e 256 Mbytes de memória Ram. Esta especificação está ligada ao tamanho dos arquivos que o sistema tem que gerenciar. O seu funcionamento em computadores mais acanhados é possível, só que as respostas são mais demoradas.

Durante a elaboração do sistema foram utilizados programas bastante conhecidos e com tradição, como o AutoCad Map e o ArcGIS. A escolha, como já citado anteriormente, esteve focada no conhecimento do potencial de cada um deles para o propósito do trabalho e principalmente pelo domínio de seu uso.

A utilização do ImageMapper para transformar o SIG Corumbá IV em páginas html foi uma solução atraente porque possibilitou, através do DreamWeaver, a construção de vários links criando novas formas de acesso às informações do PA-SALVC/IV. Inicialmente pensou-se em desenvolver um aplicativo em VBA no ArcGIS para ampliar o rol de opções default , entretanto este não pode ser acessado no visualizador ArcReader.

Idealizado para ser utilizado em computadores pessoais, o SIG Arqueologia pode ser disponibilizado na Internet, após alguns ajustes. A adoção desse caminho é interessante. A Internet, um fenômeno da era digital, tem se expandido numa velocidade fantástica. Estudo publicado pela Conferência da ONU para o Comércio e o 
Desenvolvimento, em Genebra, segundo o jornal Estadão ${ }^{10}$, afirma que existem aproximadamente 676 milhões de usuários de Internet no mundo, 11,8\% da população do planeta. Com números assim não se questiona a eficiência da difusão da informação por esse canal.

Concluindo, pode-se afirmar que a solução do SIG direcionado à inclusão social, numa estratégia de socialização do conhecimento produzido numa pesquisa de porte como a do PA-SALV-C/IV, apesar de alguns senões, ainda é extremamente atraente. O SIG Arqueologia dinamiza o acesso aos dados, evitando a leitura estática dos relatórios. Mesmo com as restrições já discutidas, a observação de alguns planos de informação onde se associou por exemplo, proximidade cultural (tradição) com zonas geoarqueoambientais, ou nível de integridade com declividade, pode-se lançar luz à alguma especulação que por ventura um usuário estivesse fazendo. Embora as limitações com respeito ao computador ideal possam dificultar o acesso individual, o uso desse material em escolas ou bibliotecas públicas como ferramenta de pesquisa ou de apoio ao professor é de valor inquestionável.

Com respeito ao SIG preditivo, novamente reforça-se a idéias de que pesquisas continuem a ser feitas experimentando soluções, de modo que num futuro breve possamos ter mapas de potencial arqueológico confiáveis e precisos.

Sobre o Sistema Gerenciador do Patrimônio Arqueológico Nacional seria importante o IPHAN e os profissionais de Arqueologia promoverem seminários no sentido de alcançar o aprimoramento dos formulário, atendendo às especificidades regionais.

Como recomendação final, seria interessante que outros projetos de pesquisa utilizassem a tecnologia de SIG como instrumento de socialização do conhecimento e que disponibilizassem na Internet o máximo possível de informações. Não se preserva o que não se conhece.

10 "Brasil é nova fronteira da internet, diz ONU” - 20/12/2004

http:www.link.estadao.com.br/index.cfm?id_conteudo=2035 


\section{REFERÊNCIAS BIBLIOGRÁFICAS}

BAENA PREYSLER, Javier. La Arqueología peninsular y los SIG: presente y futuro. ArqueoWeb - Revista sobre Arqueología en Internet - ISSN: 1139-9201. mayo 2003 [online]. outubro de 2004. Available from Eorld Wide Web: URL: http://www.ucm.es/info/arqueoweb.

BEBER, M.V. Bits, Bytes e Arqueologia : algumas considerações sobre a utilização da informática. In: REUNIÃO CIENTÍFICA DA SOCIEDADE DE ARQUEOLOGIA BRASILEIRA, 8., 1995, Porto Alegre. Anais... Porto Alegre: SAB, 1995. v.1.

BEBER, M.V., PEIXOTO, J.L.S. As possibilidades de utilização do geoprocessamento na arqueologia. In: CONGRESSO DA SOCIEDADE DE ARQUEOLOGIA BRASILEIRA, 9., 1997, Rio de Janeiro. Anais...Rio de Janeiro: SAB, 1997.

BERRY III, Joseph W. Historic Sanborn Maps in the Digital Age: City of New Orleans. Journal of GIS in Archaeology, Volume I - April 2003. [online]. outubro de 2004. Available from Eorld Wide Web: URL: http://www.esri.com/library/journals/archaeology/.

BOX, Paul. Safeguarding the Plain of Jars: Megaliths and Unexplodede Ordenance in the Lao People’s Democratic Republic. Journal of GIS in Archaeology, Volume I - April 2003. [online]. outubro de 2004. Available from Eorld Wide Web: URL: http://www.esri.com/library/journals/archaeology/.

BREMAN, Joseph. Marine Archaeology Goes Underwater with GIS. Journal of GIS in Archaeology, Volume I - April 2003. [online]. outubro de 2004. Available from Eorld Wide Web: URL: http://www.esri.com/library/journals/archaeology/. 
BREWSTER, Alice; BYRD, Brian F.; REDDY, Seethan.Cultural Landscapes of Coastal Foragers: An Example of GIS and Drainage Catchment Analysis from Southern California. Journal of GIS in Archaeology, Volume I - April 2003. [online]. outubro de 2004. Available from Eorld Wide Web: URL: http://www.esri.com/library/journals/archaeology/.

BUARQUE, A., CORREA, F. Cartografia do Estado do Rio de Janeiro.In : CONGRESSO DA SOCIEDADE DE ARQUEOLOGIA BRASILEIRA, 9., 1997. Anais.... Congresso da Sociedade de Arqueologia Brasileira. Rio de Janeiro, 1997.

CÂMARA, G.; DAVIS, C.; MONTEIRO, A . M. Introdução à ciência da geoinformação [online]. Junho de 2001. Available from Eorld Wide Web:< URL:http://www.dpi.inpe.br/gilberto/livro/>.

CAMPOS, A. B.; BARBALHO, M. G. S.; JÁCOMO, S. A. Identificação de níveis de terraços em imagem LANDSAT7-TM através do emprego de técnicas de processamento digital. In: Anais X Simpósio Brasileiro de Sensoriamento Remoto, p. 251-255, seção poster. Foz do Iguaçú: 21 a 26 de abril de 2001.

COMER, Douglas C. Environmental History at an Early Prehistoric Village: Site Analysis at Beidha, in Southern Jordan. Journal of GIS in Archaeology, Volume I - April 2003. [online]. outubro de 2004. Available from Eorld Wide Web: URL: http://www.esri.com/library/journals/archaeology/.

CRAIG, Nathan; ALDENDERFER, Mark. Preliminary Stages en the Development of a Real-Time Digital Data Recording System for Archaeological Excavation Using ArcView GIS 3.1. Journal of GIS in Archaeology, Volume I - April 2003. [online]. outubro de 2004. Available from Eorld Wide Web: URL: http://www.esri.com/library/journals/archaeology/. 
DAVIS, C. Geometria computacional para SIG [online]. Junho e 2001.Available from Eorld Wide Web: <URL:http://www.dpi.inpe.br/gilberto/livro/>.

DUREKA, J. Thomas ; MOORE, Roger G.. A Gezetter of Archaeological Sites and Cultural Resource Surveys Surrounding the Big Thicket National Preserve. Journal of GIS in Archaeology, Volume I - April 2003. [online]. outubro de 2004. Available from Eorld Wide Web: URL: http://www.esri.com/library/journals/archaeology/.

DYSON-BRUCE, Lynn. Historic Landscape Assessment: The East of England Experience Paper Product to GIS Delivery. Journal of GIS in Archaeology, Volume I April 2003. [online]. outubro de 2004. Available from Eorld Wide Web: URL: http://www.esri.com/library/journals/archaeology/.

FRANCO, M.C.B. O uso de imagens de satélite para a localização de sítios arqueológicos. In: REUNIÃO CIENTÍFICA DA SOCIEDADE DE ARQUEOLOGIA BRASILEIRA, 10.,1999, Recife. Anais... Recife : SAB, 1999.

, Sistema de Informações Geográficas aplicado à arqueologia. In: REUNIÃO CIENTÍFICA DA SOCIEDADE DE ARQUEOLOGIA BRASILEIRA, 8., Porto Alegre. Anais... Recife: SAB, 1995.

FRIEDMAN, Richard A.; STEIN, John R.; BLACKHORSE JR, Taft. A Study of a PreColumbian Irrigation System at Newcomb, New Mexico. Journal of GIS in Archaeology, Volume I - April 2003. [online]. outubro de 2004. Available from Eorld Wide Web: URL: http://www.esri.com/library/journals/archaeology/.

FURTADO, Antônio L.; SANTOS, C.S. dos. Organização de Banco de Dados. Rio de Janeiro: Campus, 1988. 
JENNINGS, Justin; CRAIG, Nathan. Using GIS for Politywide Analysis of Wari Imperial Political Economy. Journal of GIS in Archaeology, Volume I - April 2003. [online]. outubro de 2004. Available from Eorld Wide Web: URL: http://www.esri.com/library/journals/archaeology/.

JOHNSON, Ian; WILSON, Andrew. Making the Most of Maps: Field Survey on Island of Kythera. Journal of GIS in Archaeology, Volume I - April 2003. [online]. outubro de 2004. Available from Eorld Wide Web: URL: http://www.esri.com/library/journals/archaeology/.

JOHnSON, Ian; WILSON, Andrew. The TimeMap Project: Developing Time-Based GIS Display for Cultural Data. Journal of GIS in Archaeology, Volume I - April 2003. [online]. outubro de 2004. Available from Eorld Wide Web: URL: http://www.esri.com/library/journals/archaeology/.

KNEIP, Andreas. O povo da lagoa: o uso do SIG para modelamento e simulação na área arqueológica do Camacho. 2004. Tese (Doutorado em Arqueologia)- Faculdade de Filosofia, Letras e Ciências Humanas, Universidade de São Paulo, 2004.

MARTINS, D.C. et. al. Projeto de Salvamento Arqueológico Pré-histórico da UHE Serra da Mesa: subprograma devolução social e multimeios: software educativo e vídeos. In: UNIVERSIDADE FEDERAL DE GOIÁS. Museu antropológico. Goiânia: UFG/MA, 1998. v.10. (relatório final).

MARTINS, D. C. Arqueologia da Serra da Mesa: Planejamento, gestão e resultados de um projeto de salvamento. São Paulo, 1999. Tese ( Tese de Doutorado em Arqueologia) Universidade de São Paulo, 1999. 
MARTINS, D.C. et. al. Arqueologia de Cana Brava: resultados de um projeto de salvamento. In: UNIVERSIDADE FEDERAL DE GOIÁS. Museu antropológico. Laboratório de Arqueologia.. Goiânia: UFG/MA, 2001. 4v. (relatório final)

MARTINS, D.C. et. al. UHE Corumbá IV: da arqueología pré-colonial aos dias atuais. In: UNIVERSIDADE FEDERAL DE GOIÁS. Museu antropológico. Laboratório de Arqueologia.. Goiânia: UFG/MA, 2004. (relatório final)

MENEZES, U. T. B. de Arqueologia de Salvamento no Brasil: Uma avaliação crítica. Rio de Janeiro: SPHAN, 1988. (Texto apresentado no Seminário sobre Salvamento Arqueológico).

MONTEIRO, A . M.; CÂMARA, G. ; FUKS, S. Análise espacial de dados geográficos [online]. Junho de 2001. Available from Eorld Wide Web: <URL:http://www.dpi.inpe.br/gilberto/livro/>

MORAIS, J. L. Arqueologia de Salvamento no Estado de São Paulo. Dédalo, São Paulo, n. 28, 1990.

, SIG-Arqueologia : Perspectivas em aplicação em programas de pesquisa. In: REUNIÃO DA SOCIEDADE DE ARQUEOLOGIA BRASILEIRA, 8., 1995, Porto Alegre. Anais ... Porto Alegre : SAB, 1995. v.1.

\section{Perspectivas geoambientais da arqueologia do paranapanema}

paulista. São Paulo, 1999. Tese ( Livre-docência) - Universidade de São Paulo, 1999. 
, Arqueologia do Brasil. In: Workshop Arqueológico de Xingó, 2002, Canindé do São Francisco-Sergipe. Anais... Canindé do São Francisco-Sergipe: UFS/Petrobrás/MAX, 2002. p. 21-26.

MORAIS, J.L. , NAZARENO, N. R. X., MORAES, L. B., SANDOVAL, R. J. C. E.J.F. Projeto de Salvamento Arqueológico Pré-histórico da UHE Serra da Mesa: subprobrama SIG - Arqueologia (Geoprocessamento). In: UNIVERSIDADE FEDERAL DE GOIÁS. Museu Antropológico. Goiânia: UFG/MA, 1998. v.2. (Relatório final).

PAIVA, J. A . ; CASANOVA, M. ; CARTEXO, R. ; CÂMARA, G. Banco de dados geográfico [online]. Junho de 2001. Available from Eorld Wide Web: URL:http://www.dpi.inpe.br/gilberto/livro/.

PAREDES, E. A. Sistema de informações geográficas: princípios e aplicações (geoprocessamento). São Paulo: Érica, 1994.

PEIXOTO, J.L.S. Uso de sensoriamento remoto e sistema de informação Geográfico em arqueologia. In: CONGRESSO DA SOCIEDADE DE ARQUEOLOGIA BRASILEIRA, 9., 1997, Rio de Janeiro. Anais ....Rio de Janeiro : SAB, 1997.

PEIXOTO, J.L.S., ISQUIERDO, S.W.G. Projeto Vitória Régia: diagnóstico geoambiental e arqueológico da bacia hidrográfica da Lagoa Negra. Pantanal sul-matogrossense. In: CONGRESSO DA SOCIEDADE DE ARQUEOLOGIA BRASILEIRA, 9., 1997, Rio de Janeiro. Anais ....Rio de Janeiro : SAB, 1997.

QUINTANILHA, J. A. Entrada e conversão de dados: processos de construção de bases digitais de dados espaciais. In: Anais do III Simpósio Brasileiro de Geoprocessamento, p. 29-60, 1995. 
REDMAN, C.L. Multistage fieldwork and analytical techniques. American Antiquity, 1973.

RIORDAN, Rebecca M. Microsoft SQL Server 2000: Programando. Tradução Flávia B. Cruz, Lucyana R. de Oliveira. São Paulo: Pearson Educacion, 2002.

RODRIGUES, M. SIGs e suas características no Brasil. In: Anais do III Simpósio Brasileiro de Geoprocessamento, p. 11-23, 1995.

RODRIGUES, P.H. , VILLAÇA, S. Sistemas municipais de informações : subsídios para a utilização de geoprocessamento. Fator GIS - Revista de Geoprocessamento, v.9, p. 3539, 1995.

RUBIN, J.C.R., SILVA, N.F. Projeto Sistema Geográfico de Informação do potencial arqueológico do aglomerado urbano de Goiânia : considerações preliminares sobra a área piloto. Revista de divulgação Científica, Goiânia : IGPA/UCG, v.3, p.125-34, 1999.

SEIXAS, R. B.; FIGUEIREDO, L. H.; CARVALHO, P. C. P.; SILVA, C. A. Uma metodologia para geração de modelos de elevação a partir de curvas de nível. II Workshop Brasileiro de GeoInformática ; São Paulo, SP, Brasil ; 2000. [online] dezembro de 2004. Available from Eorld Wide Web: URL: http://www.tecgraf.pucrio.br/geoinfo2000/anais/020.pdf /.

TENÓRIO, M.C. Utilização da informática na reconstituição de um sítio arqueológico. In: REUNIÃO CIENTÍFICA DA SOCIEDADE DE ARQUEOLOGIA BRASILEIRA, 8., 1995, Porto Alegre. Anais ... Porto Alegre: SAB, 1995. v.1. 
THOMAZ, Rosângela C.C. O uso de SIG na predição da localizacão de sítios arqueológicos: um estudo de caso na bacia do Paraná superior.2002. Tese (Doutorado em Arqueologia)- Faculdade de Filosofia, Letras e Ciências Humanas, Universidade de São Paulo, 2002.

THOMAZ, R.C.C.; IMAI, N.N.; SILVA. E. A.;TSUCHIYA, I. Visualização cartográfica como ferramenta de suporte à implementação de um modelo preditivo em arqueologia: um estudo de caso. In : SIMPÓSIO BRASILEIRO DE GEOMÁTICA, 9-13 de julho 2002. Anais.... SIMPÓSIO BRASILEIRO DE GEOMÁTICA. Presidente Prudente, 2002.

TSUCHIYA, I.;TACHIBANA, V.M.; IMAI, N.N.; THOMAZ, R.C.C. Utilização de regressão logística para avaliação de prováveis áreas de ocupações pretéritas. In : SIMPÓSIO BRASILEIRO DE GEOMÁTICA, 9-13 de julho 2002. Anais.... SIMPÓSIO BRASILEIRO DE GEOMÁTICA. Presidente Prudente, 2002.

VIESCAS, JOHN. Microsoft access 2000: Guia Autorizado. Tradução Lavio Pareschi.São Paulo: Makron Books, 2000. 1048 p 


\section{ANEXO}

SIG Arqueologia 


\section{Instruções}

Este CD Rom acompanha a Tese de doutorado SIG ARQUEOLOGIA: Aplicação em projeto de Arqueologia, apresentada ao Programa de Pós-Graduação, área de concentração em Arqueologia, do Museu de Arqueologia e Etnologia da Universidade de São Paulo. Este trabalho foi desenvolvido por Nilton Ricetti Xavier de Nazareno e orientado pelo Prof. Dr. José Luiz de Morais.

O CD Rom é auto-executável e opera através de menus interativos. Na possibilidade da não execução automática, ativar o arquivo início.html com o Explorer na raiz do CD.

Para o seu correto funcionamento, é necessário que o computador tenha como sistema operacional o Windows 2000 ou $\boldsymbol{X P}$ e que os programas Acrobat e ArcReader 8.3 estejam instalados. Na eventualidade da ausência desses programas, os instaladores estão presentes nas versões Acrobat 6.0 e ArcReader 9.0.

Neste CD Rom encontram-se os dados relativos ao projeto de salvamento arqueológico da UHE Corumbá IV, executado pela equipe do Laboratório de Arqueologia do Museu Antropológico da Universidade Federal de Goiás.

Como parte integrante do SIG Arqueologia foi incluído ainda, o arquivo correspondente a esta Tese para que outros usuários possam compartilhar do experimento. 
CD SIG ARQUEOLOGIA

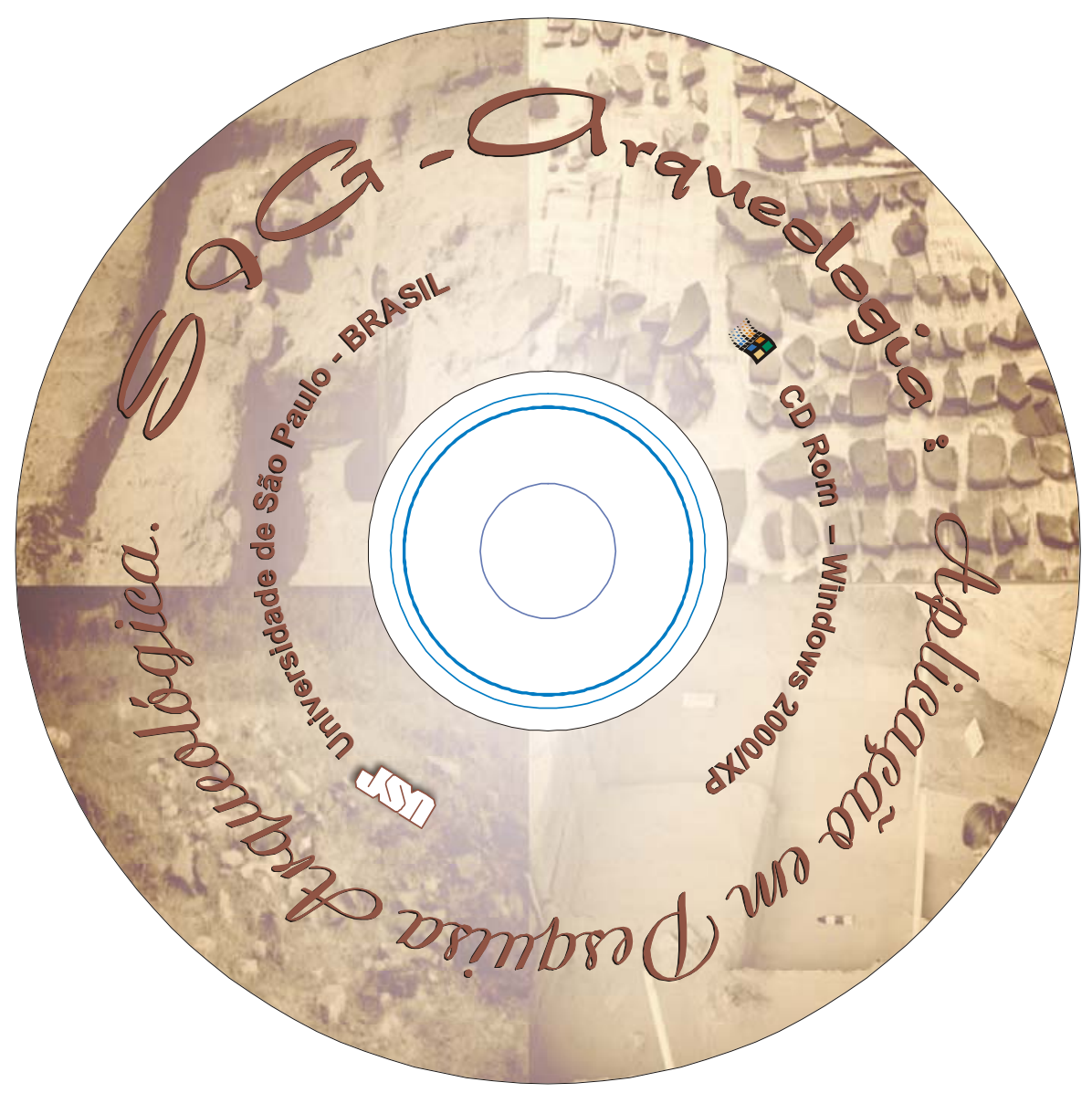

